UNIVERSIDADE DE SÃO PAULO

ESCOLA DE ENFERMAGEM

VIVIAN CÉSAR BETELI

ACOMPANHAMENTO DO DESENVOLVIMENTO INFANTIL EM CRECHES

São Paulo

2006 
VIVIAN CÉSAR BETELI

\section{ACOMPANHAMENTO DO DESENVOLVIMENTO INFANTIL EM CRECHES}

Dissertação apresentada à Escola de Enfermagem da Universidade de São Paulo, para obtenção do título de Mestre em Enfermagem.

Área de concentração: Enfermagem Pediátrica.

Orientadora:

Prof $^{a}$. Dr ${ }^{a}$. Magda Andrade Rezende

São Paulo

2006 


\section{AGRADECIMENTOS}

À professora Magda Andrade Rezende, pela habilidade para ensinar, pelo carinho, paciência e por me ajudar nas diferentes fases do meu desenvolvimento como pessoa, aluna e enfermeira.

Aos meus pais, Walmir e Rita; irmãos, Vinícius, Natália e Vitor; tios e primos, pela confiança, incentivo e apoio em todas as minhas decisões.

Aos meus avós Ema, Luís, Napoleão e Irene (in memorian) por me ensinarem valores muito preciosos que utilizarei em toda minha vida.

Ao Júnior, pelo amor, ajuda, dedicação e paciência pelos momentos que estive afastada para me dedicar a este trabalho.

À professora Maria De La Ó Ramallo Veríssimo, pela amizade, carinho e discussões que muito contribuíram para meu aprendizado.

Às minhas queridas amigas Daniela, Luciana e Letícia por estarem presentes em todos os momentos da minha vida.

Às minhas queridas amigas enfermeiras, companheiras de graduação e pósgraduação: Ana Cláudia, Roberta e Juliana pela amizade, apoio, incentivo e por acreditarem em mim.

À Fernanda Guedes de Lima, pela amizade e ajuda na primeira fase desta pesquisa.

À Nadir Aparecida Lopes pela atenção, disponibilidade e inúmeras ajudas prestadas.

Às creches, crianças e famílias por permitirem que este trabalho fosse realizado.

À todos os funcionários da EEUSP por participarem e ajudarem na minha formação. 
À FAPESP pela concessão de bolsa de iniciação científica (processo 00/11890-7) durante o início dentre trabalho e ao CNPq pela concessão de bolsas de iniciação científica (processo 248/2002 ) e mestrado para continuação da pesquisa.

Ao professor Jair Lício Ferreira dos Santos pela importante contribuição em algumas fases da análise estatística.

À Rejane Augusta de Oliveira Figueiredo por realizar a última fase da análise estatística.

À Prof ${ }^{\mathrm{a}} \operatorname{Dr}^{\mathrm{a}}$ Márcia Regina Marcondes Pedromônico (in memorian) pela atenção e fornecimento de materiais necessários para o desenvolvimento do trabalho. 
Beteli VC. Acompanhamento do desenvolvimento infantil em creches. [dissertação] São Paulo: Escola de Enfermagem da USP; 2006.

\section{RESUMO}

O período da vida em que as crianças freqüentam instituições de educação infantil (creches e pré-escolas) corresponde a uma fase crítica para o desenvolvimento. Dentre as áreas do desenvolvimento, a linguagem é uma das mais vulneráveis uma vez que necessita intensamente da intervenção de outrem. Devido à importância do desenvolvimento acredita-se que acompanhá-lo é uma ação básica de saúde, bem como um importante cuidado de enfermagem. Os objetivos desta pesquisa foram: descrever perfil de desenvolvimento, especialmente no que diz respeito às habilidades de linguagem, de crianças hígidas de 0 a 6 anos de idade incompletos que freqüentam instituição de educação infantil. Trata-se de um estudo quantitativo, descritivo e longitudinal (coorte) com amostra não probabilística. Utilizou-se o Teste de Triagem de Desenvolvimento de Denver II (TTDD II). No período de 2001 a 2004 foram realizadas 150 aplicações do TTDD II em crianças de 4 meses e 23 dias até 5 anos 7 meses e 11 dias. Tais crianças freqüentavam instituições de educação infantil consideradas de boa qualidade localizadas na cidade de São Paulo. Os critérios de inclusão foram: idade gestacional conhecida (para menores de 2 anos), ausência de mal formação congênita, não ser estrangeira (devido à área de linguagem), e nunca ter freqüentado outra creche. A condição sócio-econômica das famílias era homogênea, sendo a renda média de 7,60 salários mínimos, portanto, superior à renda média per capita na região metropolitana de São Paulo no mesmo período, que era 4,28 salários mínimos. Os resultados foram estatisticamente iguais nas 3 creches, tanto para o resultado global do TTDD II, quanto para a área de habilidades de linguagem isoladamente. Não houve associação estatística dos resultados em relação aos sexos. Em termos de resultado global houve melhora estatisticamente significante ao longo das 5 avaliações $\left(1^{\mathrm{a}} \times 3^{\mathrm{a}} \mathrm{p}=0,015\right)$. O desempenho da linguagem se manteve estatisticamente igual ao longo dos 5 momentos. Assim, é possível ventilar as seguintes possibilidades: as 3 instituições em questão não estão conseguindo otimizar as condições de molde a propiciar às crianças o pleno desenvolvimento de suas habilidades de linguagem, e/ou, o TTDD II não possibilitou a triagem adequada nesta área. A favor da primeira possibilidade há o fato que as habilidades de linguagem parecem declinar quando as crianças alcançam 3 anos de idade, melhorando mais tarde. Exatamente neste período o módulo educadora/crianças está abaixo no nível recomendado. Quanto à segunda possibilidade, tem-se que o TTDD II ainda não está validado para a língua portuguesa empregada no Brasil. Conclui-se que: freqüientar as creches pode ter sido benéfico para o desenvolvimento das crianças no que tange ao desenvolvimento global. No caso da das habilidades de linguagem há necessidade de outras pesquisas.

Palavras-chave: Desenvolvimento infantil, Creches, Educação infantil, Enfermagem pediátrica, Teste de Triagem de Desenvolvimento de Denver. 
Beteli VC. Follow-up of the child development in day care centers. [dissertação] São Paulo: Escola de Enfermagem da USP; 2006.

\begin{abstract}
The period of life in which children are enrolled in institutions of child education (pre-school and day care centers) is a critical phase for the child development. Among the developmental areas, the language is the most susceptible since it strongly needs someone else's intervention. Due to the development importance child follow-up is a basic health care in nursing. The purpose of this study was to describe the development profile, specially regarding language abilities of healthy children with ages ranging from 0 to 6 incomplete years, who were enrolled in child day care centers. This is a quantitative, descriptive and longitudinal (cohort) study with a non-probabilistic sampling. The Denver II Developmental Screening Test (DDST II) was used. From 2001 to 2004, 150 DDST III were applied in children with ages varying from 4 months and 23 days up to 5 years, 7 months and 11 days. These children were enrolled in good quality Day Care Centers located in the city of São Paulo. The criteria of inclusion were as follows: identified gestational age (for those under the age of 2 years), lack of congenital malformation, born Brazilian (due to the language area) and never been enrolled in a day care center before. The socioeconomic condition of the families was homogeneous, average of 7.60 minimum wage, thus, above the mean income per capita in the metropolitan area of São Paulo, in the same period, which was 4.28 minimum wages. The results were statistically equal in three Day Care Centers, both for the global result of the DDST II and for the language ability areas alone. There was no statistical association of the results regarding gender. In terms of global results, a statistically significant improve was observed in the five evaluations performed $\left(1^{\mathrm{a}} \times 3^{\mathrm{a}} \mathrm{p}=0.015\right)$. Language performance maintained statistically equal on these five moments. Consequently, it was possible to demonstrate the following likelihood features: the three institutions were not able to optimize the conditions needed to give the child full development of his/her language abilities and/or the DDST II did not allow an adequate screening in this area. In the first option, it seems that language abilities may decrease when the child reaches the age of three years and developing later. At this moment, the educator/child module is below the recommended level. Regarding the second option, the DDSTII is not yet validated for the Portuguese language in Brazil. It was concluded that to enroll children in day care centers seems to be effective for the global child development. Regarding language abilities further studies are still needed.
\end{abstract}

Keywords: Child development; Child Day Care Centers; Child Rearing, Pediatric Nursing, Denver Developmental Screening test 


\section{SUMÁRIO}

1 INTRODUÇÃO

$\begin{array}{ll}\text { 1.1 Desenvolvimento infantil } & 7\end{array}$

1.2 Fatores de risco para o desenvolvimento infantil 9

1.3 Áreas do desenvolvimento infantil 11

1.4 Desenvolvimento da linguagem $\quad 12$

$\begin{array}{ll}\text { 1.5 Desenvolvimento em creches e pré-escolas } & 15\end{array}$

1.6 A Enfermagem e o acompanhamento do desenvolvimento infantil 17

$\begin{array}{ll}1.7 \text { Justificativa da pesquisa } & 19\end{array}$

$\begin{array}{lr}2 \text { OBJETIVOS } & 20\end{array}$

3 MÉTODO $\quad 21$

3.1 Tipo de pesquisa $\quad 21$

3.2 Local do estudo $\quad 21$

3.3 Formação do grupo do estudo 23

3.4 Teste de Triagem de Desenvolvimento de Denver II (TTDD II) 23

3.4.1 Aplicação do TTDD-II $\quad 25$

3.5 Cuidados éticos 28

3.6 Análise dos dados 30

4 RESULTADOS 31

4.1 Caracterização dos participantes $\quad 31$

4.2 Resultados do TTDD II $\quad 34$

4.2.1 Avaliação global $\quad 34$

4.2.1.1 Segundo ordem temporal das triagens 36

$\begin{array}{ll}\text { 4.2.1.2 Segundo as idades das crianças } & 37\end{array}$

4.2.2 Área de linguagem $\quad 40$

4.2.2.1 Segundo ordem temporal das triagens 41

4.2.2.2 Segundo as idades das crianças 41

5 DISCUSSÃO

6 CONCLUSÕES E RECOMENDAÇÕES 56

$\begin{array}{ll}\text { REFERENCIAS } & 57\end{array}$

$\begin{array}{ll}\text { ANEXOS } & 63\end{array}$ 


\section{INTRODUÇÃO}

\subsection{Desenvolvimento infantil}

O desenvolvimento humano consiste em mudanças físicas, sociais, cognitivas, psíquicas e morais que ocorrem ao longo do ciclo vital. Tais mudanças progridem rumo ao aperfeiçoamento e sofisticação e, em geral, ocorrem de acordo com uma ordem pré-estabelecida. No caso da infância, o desenvolvimento deve ser visto com atenção porque é o alicerce para o restante da vida. Assim, podemos dizer que o desenvolvimento infantil é um "processo vital que engloba crescimento, maturação e aprendizagem. Como resultados da inter-relação íntima entre estes três fenômenos, ocorrem modificações quantitativas e qualitativas no funcionamento da pessoa" (Veríssimo, Sigaud, 1996).

Para exemplificar estes três fenômenos, veja-se o andar, que, aliás, é um marco do desenvolvimento. É necessário haver um aumento das massas muscular e esquelética (crescimento) para a criança sustentar seu peso, a maturação do sistema neurológico para aquisição do equilíbrio e coordenação dos passos e finalmente o adulto (o ambiente, podemos dizer) deve oferecer oportunidades para a criança realizar várias tentativas até aprender a realizar esta ação.

Bronfenbrenner (1996) define desenvolvimento como uma mudança duradoura na maneira pela qual uma pessoa percebe e lida com o seu ambiente.

Percebe-se que as duas definições consideram apenas mudanças, porém, Bee (2003) enfatiza que além de mudanças existe continuidade no desenvolvimento porque cada criança leva consigo um núcleo de individualidade, ou seja, cada criança tem um estilo particular, uma determinada série de habilidades, uma personalidade 
específica, e essas qualidades se mantêm com certa consistência ao longo dos anos, inclusive na vida adulta.

Para entendermos o desenvolvimento precisamos examinar tanto a natureza como o meio ambiente, tanto a biologia como a cultura, e o modo como eles interagem para explicar a consistência e a mudança (Bee, 2003).

Atualmente é muito enfatizada a importância da interação entre a expressão da carga genética e o ambiente para que o desenvolvimento ocorra da melhor maneira possível. Teóricos como Wallon (Galvão, 2000) e Vygotsky (Taille, Oliveira, Dantas, 1992; Vygotsky, 2000) defenderam esta perspectiva interacionista ao estudarem o desenvolvimento infantil e esta é a mais aceita atualmente.

Para compreender o desenvolvimento da criança precisamos ir além da própria criança e dos padrões desenvolvimentais intrínsecos que possam existir; precisamos ir além da díade mãe-criança ou pai-criança. Precisamos examinar toda a ecologia do desenvolvimento: o padrão de interação na família e as influências da cultura mais ampla sobre aquela família (Bee, 2003).

Assim, a tipologia estabelecida por Bronfenbrenner (1996) se torna extremamente útil. Para este é importante considerar o contexto a partir de uma perspectiva ecológica. Este sistema ecológico é composto por três elementos: microssistemas, como a família e a escola, nos quais a criança está diretamente envolvida; exossistemas como, por exemplo, o trabalho dos pais e macrossistemas como a subcultura étnica e a sociedade, ou como a cultura mais ampla em que a família vive. 
Porém tentar entender o desenvolvimento pela perspectiva ecológica é imensamente complicado porque é difícil ter presentes todos os elementos do sistema ao mesmo tempo, sem falar em tentar examinar, de forma simultânea, todas as partes relevantes (Bee, 2003).

\subsection{Fatores de risco para o desenvolvimento infantil}

Sabe-se que o desenvolvimento infantil pode ser prejudicado por inúmeros fatores. Figueiras, Souza e Pedromônico (2003) enumeram vários fatores de risco para problemas de desenvolvimento, que apresentamos agrupados:

1. condições diretamente relacionadas à criança: erros inatos do metabolismo, malformações congênitas, síndromes genéticas, prematuridade, hipóxia cerebral (grave), meningites, kernicterus, encefalites, otites médias de repetição e infeções respiratórias. Como se vê esta categoria agrupa as condições ligadas à herança genética e área biológica. No entanto, cumpre ressaltar que mesmo estas estão vinculadas à condições ambientais. Por exemplo, a ocorrência de afecções genéticas como consequiência de mutações desencadeadas por desastres ambientais. Ou, o grau de seqüelas como decorrência de precário atendimento de saúde, o qual é expressão de uma política de saúde.

2. características familiares: educação materna e estresses intra-familiares como violência, abuso e maus tratos. Tais fatores estão ligados à esfera social e cultural. Por exemplo, a crença popular de que "criança não pensa", corriqueira em nosso país, pode determinar comportamentos familiares que desfavorecem (ou até impedem) o pleno desenvolvimento das potencialidades infantis. No 
entanto, não se podem considerar fatores sociais e culturais como entidades desligadas de quaisquer outras, como se tivessem sua existência própria. Vale um exemplo. A família que veicula e perpetua a representação de que "criança não pensa" está mais propensa a prejudicar o desenvolvimento infantil na vigência de um fator ambiental da esfera econômica e política, tal como uma renda muito baixa. Como se vê, a análise dos fatores causais é necessária para que se compreenda seu impacto de modo mais acurado. Mas, de modo algum, isto torna a compreensão do sistema mais fácil.

3. fatores macroambientais: condições precárias de saúde e falta ou precariedade de recursos sociais e educacionais. Estes fatores foram lembrados ao se apresentar os dois anteriores.

Além disto, não se deve desconsiderar a realidade de muitas crianças que são cuidadas e educadas por outros adultos, quer em creches, pré-escolas, escolas, e abrigos de caráter permanente ou temporários. Assim, a questão da qualidade do cuidado e educação nestas instituições também precisa ser considerada, tanto quanto a da qualidade do cuidado no âmbito da família.

Este trabalho está centrado nas questões concernentes às instituições de educação infantil (creches e pré-escolas). Nestas é imperativo focalizar e potencializar as questões referentes à qualidade do cuidado e da educação, especialmente a primeira, sendo cabível perguntar como os adultos estão provendo as condições adequadas para que as crianças possam se desenvolver plenamente. Sabese que os primeiros anos de vida, especialmente os três iniciais, são cruciais para aquisição de conhecimentos e habilidades, motivo pelo qual é importante a promoção do desenvolvimento infantil (Shore, 2000). 


\section{3 Áreas do desenvolvimento infantil}

O desenvolvimento infantil foi explorado por vários teóricos e cada um enfatizou uma área, que em seu entender, poderia ser a mais importante ou que lhe despertava maior interesse. Por exemplo, Freud se deteve no aspecto psicossexual, Erikson no psicossocial e Kohlberg no ético-moral (Cloninger, 1999; Wong, 1999).

Wong (1999), autora bastante utilizada pela enfermagem pediátrica brasileira, propõe a divisão do desenvolvimento infantil nas seguintes áreas:

- desenvolvimento físico (maturação esquelética, neurológica, desenvolvimento dos sistemas orgânicos e desenvolvimento motor);

- desenvolvimento da personalidade (desenvolvimento psicossexual e psicossocial);

- desenvolvimento mental (desenvolvimento cognitivo, da linguagem, moral e espiritual);

- desenvolvimento do auto-conceito (imagem corporal e auto-estima).

Como se vê, o desenvolvimento humano, exatamente por não ser "natural", e sim produto de um olhar específico do teorista, presta-se a inúmeras classificações.

Frankenburg, conhecido estudioso da área de saúde infantil, também optou por uma divisão do desenvolvimento em seu teste (Teste de Triagem de Desenvolvimento de Denver II - TTDD II), quais sejam as áreas: pessoal-social, motor fino-adaptativo, linguagem e motor grosseiro (Frankenburg et al., 1992a).

É lógico que o desenvolvimento da criança não se dá se modo fragmentado, mas o uso de tipologias facilita para o profissional de enfermagem, o traçado de metas em relação ao cuidado e ao bem-estar da criança, papel da equipe de 
enfermagem em nosso entender, bem como no de colegas (Beteli et al., 2003; Brêtas, Cassula, Reis, 2001; Rezende et al., 2003, 2005a, 2005b, 2005c). Além disto, ajuda o profissional a tornar claro este tema tão amplo e complexo que é o desenvolvimento.

Deteremo-nos nas 4 áreas em conjunto do TTDD-II e especificamente nas habilidades de linguagem . Esta escolha se deu devido a uma trajetória de estudos que iniciamos em 2001, ao acompanharmos o desenvolvimento de crianças que freqüentam instituições de educação infantil da cidade de São Paulo, e que a linguagem era a área mais afetada (Beteli et al., 2003; Rezende et al., 2003, 2005a, 2005b, 2005c).

\subsection{Desenvolvimento da linguagem}

Para Vygotsky, a linguagem tem duas funções básicas: a de intercâmbio social e a de pensamento generalizante (Taille, Oliveira, Dantas, 1992). Wallon também enfatiza a importância do desenvolvimento da linguagem, que, em seu entender, é essencial para os progressos do pensamento porque o expressa e age como estruturadora do mesmo (Galvão, 2000). Portanto, a linguagem é o meio pelo qual os seres humanos interagem com outras pessoas em diferentes ambientes como família, escola, trabalho e grupos sociais tendo assim a possibilidade de expressar idéias, vontades, medos, planos e dúvidas.

O processo desenvolvimental, nos bebês e nas crianças pequenas, dos sons da pré-linguagem e dos gestos até a linguagem, segue etapas bastante comuns: (Bee, 2003)

1. Fase pré-linguistica: antes da primeira palavra e subdivide-se em: 
a. percepção inicial da linguagem (discrimina sons de fala);

b. primeiros sons: choro, arrulho (risos e sons vocálicos que aparecem de $1 \mathrm{a}$ 2 meses), balbucio (combinações vogal consoante como: dada, papa surgem de 6 a 9 meses) e jargão (balbucio com entonações variadas surge de 6 a 9 meses);

c. primeiros gestos: dar tchau, bater palmas, mostrar o que quer são perceptíveis na faixa etária de 9 a 10 meses;

d. linguagem receptiva (bebês começam entender significado das palavras quando apresentam 9 a 10 meses de idade)

2. Primeiras palavras: aparecem no período dos 12 aos 13 meses;

a. explosão dos nomes (aprende rapidamente novos vocábulos de 16 a 24 meses);

b. aprendizagem posterior das palavras: de 2 anos e meio para 5 anos, aumento de 10 palavras por dia;

3. Desenvolvimento da gramática:

a. primeiras frases de 2 palavras de 18 a 27 meses;

b. explosão da gramática (frases mais longas) de 27 a 36 meses;

c. frases complexas (como orações subordinadas e uso de conjunções) 30 a 48 meses;

4. Desenvolvimento do significado das palavras.

Os verdadeiros passos de gigantes ocorrem entre 1 e 4 ano de vida, na medida em que a criança passa de palavras isoladas para perguntas, negativas e ordens complexas 
Estudos recentes têm mostrado que as crianças não estão exercendo todas as suas potencialidades no que diz respeito à linguagem e isto vêm ocorrendo em diversos contextos: creches públicas, universitárias e, inclusive, escolas privadas (Rezende et al., 2003, 2005a, 2005c; Souza, Siqueira, 2003; Toledo, 2000).

Diferente destes resultados, estudo americano mostrou que crianças que ingressaram em creches de boa qualidade antes dos 6 meses de idade, tiveram melhor desempenho na linguagem aos 3 anos quando comparadas às cuidadas em casa (National Institute of Child Health Human Development- NICHD, 2000).

As crianças cujos pais conversam e lêem para elas regular e freqüentemente, empregam uma grande variedade de palavras, começam a falar mais cedo, formam frases mais complexas e aprendem a ler mais facilmente quando atingem a idade escolar (Bee, 2003).

Outra pesquisa, que corrobora o apresentado por Bee, diz respeito à educação materna. Nesta Cardoso (2001) analisou o conhecimento de mães referente ao desenvolvimento de linguagem de crianças de 0 a 24 meses. Realizou este estudo no município de Embu, região metropolitana de São Paulo, e entrevistou 4 grupos de mães segundo a escolaridade: analfabetas, com escolaridade até $4^{\mathrm{a}}$ série do ensino fundamental, da $5^{\text {a }}$ série ao final do ensino médio, e com nível superior (de outras áreas que não saúde e educação). No grupo das analfabetas $24 \%$ acertaram todas as questões, sendo que nos outros grupos a porcentagem de acertos aumentou até chegar a $42 \%$ no caso das mães que haviam cursado nível superior. Assim, demonstrou-se que a um aumento do nível de escolaridade das mães corresponde aumento de seu conhecimento acerca do desenvolvimento da linguagem infantil. Logicamente ter 
conhecimento acerca de algo não é a única condição para que se realize uma ação, mas é um importante requisito.

Estes achados nos levam a refletir a respeito de quanto o ambiente é importante: a criança pouco exposta a situações de comunicação ou a situações mais enriquecedoras, usará menos a linguagem oral prejudicando seu desenvolvimento. Assim, a defasagem de aquisição da linguagem pode constituir-se em manifestação primária do desenvolvimento prejudicado (Wertzner, 2002).

\subsection{Desenvolvimento em creches e pré-escolas}

Segundo a Lei de Diretrizes e Bases da Educação Nacional (Lei 9.394/96) creches são instituições que atendem crianças de 0 a 3 anos e pré-escolas as de 4 a 6 anos. As duas faixas etárias compreendem a educação infantil que é a primeira etapa da educação básica e tem como finalidade o desenvolvimento integral da criança em seus aspectos físico, psicológico, intelectual e social. ${ }^{1}$

A situação das crianças cuidadas nestas instituições é especialmente importante, uma vez que nelas permanecem longos períodos diários durante uma fase do desenvolvimento que é fundamental. Segundo o Conselho Nacional de Credenciamento de Creches da Austrália $^{2}$, uma criança de 5 anos chega a freqüentar a creche/pré-escola durante o mesmo período de horas utilizados para o restante da sua escolarização.

\footnotetext{
${ }^{1}$ www.mec.gov.br/legis/pdf/LDB.pdf em 23/10/2004

2 Conselho Nacional de Credenciamento de Creches. Priorizando as crianças: sistema de promoção de qualidade credenciamento. Austrália; 1993 /Mimeo/.
} 
Vale ressaltar que os resultados preliminares do censo escolar de $2005^{3}$ mostraram que 7.204.674 crianças brasileiras freqüentam creches e pré-escolas.

Assim é necessário levar em conta a qualidade do cuidado e educação que as crianças recebem nestas instituições. Para Bedregal, Margozzini e Molina (2002), e também para nós ${ }^{4}$, diga-se de passagem, garantir que as crianças tenham acesso à educação pré-escolar e escolar de alta qualidade é uma das ações para promover e proteger o desenvolvimento infantil.

No que diz respeito à qualidade em educação infantil vale mencionar Burchinal et al (2000) que realizaram estudo longitudinal com 89 crianças de diferentes classes sociais, atendidas durante seus primeiros três anos de vida em creches localizadas em diferentes regiões dos Estados Unidos. A qualidade foi verificada pela proporção adulto/criança, tamanho das classes e o comportamento do adulto frente aos interesses e necessidades infantis. Concluíram que a qualidade do cuidado na creche foi importante para predizer o desenvolvimento cognitivo e de linguagem durante os três primeiros anos de vida no caso de crianças oriundas de famílias de baixa renda.

Outro estudo, realizado nos Estados Unidos, também demonstra o efeito positivo da creche para crianças de famílias pobres que, após freqüentarem creches de boa qualidade desde os 4 meses de idade, apresentam ganhos significativos e duradouros no desenvolvimento intelectual e desempenho escolar posterior (Campbell, Ramey, 1994).

\footnotetext{
${ }^{3}$ www.inep.gov.br/imprensa/noticias/censo/escolar/news05_10.htm em 04/12/2005

${ }^{4}$ Referência ao Grupo de Pesquisas "Cuidado e Promoção da Saúde e do Desenvolvimento Infantis" da Escola de Enfermagem da USP, São Paulo.
} 
Além disto, crianças que freqüentaram creche de bom padrão de qualidade antes dos 2 anos de idade apresentaram melhores habilidades verbais aos 8 anos de idade quando comparadas com as crianças cuidadas pelos pais. O estudo foi realizado na Suécia. (Broberg et al., 1997).

\subsection{A Enfermagem e o acompanhamento do desenvolvimento infantil}

Em nosso país, a área de saúde, e em especial a de Enfermagem, vêm se preocupando com as questões relativas ao desenvolvimento infantil. Assim, vêm sendo produzidas pesquisas sobre desenvolvimento infantil em creches e pré-escolas que são, em geral, transversais ou de avaliação antes e depois de alguma intervenção (Brêtas, 1991, Brêtas, Cassula, Reis, 2001; Ferreira, 1989; Fisberg et al., 1997; Hugues, 1986; Kakehashi,1987).

No entanto, apesar de esta preocupação já estar bem presente no âmbito acadêmico, percebe-se, na prática cotidiana, que o acompanhamento do desenvolvimento infantil ainda não é realizado rotineiramente. Uma das razões, apontada por Veríssimo (2002), é que o desenvolvimento não pode ser avaliado tão

simples e objetivamente como o crescimento. O desenvolvimento, diferente do crescimento, pode ser difícil de medir e avaliar porque implica em avaliação de múltiplas aquisições. Além disto, pode ser influenciado por uma miríade de fatores tais como: sono, doença, timidez e insegurança temporária perante um avaliador desconhecido.

A maneira como a criança cresce e se desenvolve é importante indicador de suas condições de saúde. Por isso faz-se necessário entender que a promoção da 
saúde infantil compreende todas as ações diretas e indiretas que favorecem a criança a atingir seu potencial de crescimento e desenvolvimento. Uma das ações diretas que competem ao enfermeiro destaca-se o acompanhamento do crescimento e desenvolvimento (Veríssimo, 2001a) que foi definido como uma das cinco ações básicas de saúde que possuem comprovada eficácia e foram priorizadas pelo Ministério da Saúde em 1984 (Ministério da Saúde, 2002).

Em função disto, Rezende (2004) define o acompanhamento do desenvolvimento como um cuidado de enfermagem a ser exercido em qualquer âmbito no qual se cuide da criança: instituições de educação, de saúde, sociais, bem como, é claro, a própria família. Para Waldow (1998) o cuidado de enfermagem é intencional, tem vários objetivos, necessita de conhecimento, habilidades, e atitudes e não depende da cura de uma doença para acontecer.

Cuidar em instituições de educação infantil implica em: ajudar a criança a amadurecer, protegê-la de agravos e propiciar oportunidades para que faça troca de afeto com adultos cuidadores secundários (Rezende, Silva, 2002; Rezende, 2004; Rezende, Veríssimo, 2004).

Contemplar o cuidado na esfera da instituição de educação infantil significa compreendê-lo como parte integrante da educação. O cuidar de uma criança em um contexto educativo demanda a integração de vários campos de conhecimentos e a cooperação de profissionais de diferentes áreas (Ministério da Educação e do Desporto, 1998).

Frente a tantas outras questões tão prementes quanto mortalidade e morbidade não admira que o acompanhamento do desenvolvimento infantil, em nosso país, tenha sido relegado a segundo plano. No entanto, atualmente está bem claro que a 
questão da qualidade da educação infantil deve ser encarada, sob pena de continuarmos a ter uma população que ostenta lamentáveis índices de competência escolar . Segundo Setti (1994), se tivermos na pré-escola um programa de linguagem bem estruturado e delineado de acordo com o ritmo de desenvolvimento adequado, $50 \%$ das crianças que apresentam problemas de alfabetização, não teria qualquer dificuldade nesta área.

\subsection{Justificativa da pesquisa}

O período da vida em que as crianças freqüentam creches, corresponde a uma fase crítica para o desenvolvimento, e a linguagem é uma área em que a criança pode ter dificuldades maiores uma vez que necessita da intervenção de outrem.

Além disto, o acompanhamento do desenvolvimento é uma ação básica de saúde e também um cuidado de enfermagem, motivo pelo qual se propõe que seja adotado em creches e pré-escolas. Deste modo se otimiza os fatores ambientais (adultos e físicos) com vistas à promoção do desenvolvimento infantil. 


\section{OBJETIVOS}

- Descrever perfil de desenvolvimento de crianças hígidas de 0 a 6 anos de idade incompletos que freqüentam instituição de educação infantil.

- Descrever perfil de desenvolvimento de linguagem de crianças hígidas de 0 a 6 anos de idade incompletos que freqüentam instituição de educação infantil. 


\section{MÉTODO}

\subsection{Tipo de pesquisa}

Estudo quantitativo, descritivo e longitudinal (coorte) com amostra não probabilística (Polit, 2004).

\subsection{Local do estudo}

O estudo desenvolveu-se de 2001 a 2004 em três creches que também são pré-escolas. Cumpre salientar que estas instituições se auto-denominam creches motivo pelo qual passam a ser assim mencionadas daqui em diante neste trabalho. Atendem a crianças de 0 a 6 anos de idade e estão localizadas próximas umas das outras, na região oeste da cidade de São Paulo. Atendem a filhos de funcionários, docentes e alunos da universidade que as mantém.

Estas instituições foram escolhidas por serem consideradas de bom padrão de atendimento, isto é, atendem aos seguintes critérios: proporção adequada adulto/criança, organização das crianças em pequenos grupos, bom nível de educação e treinamento dos adultos, baixa rotatividade dos adultos, estabilidade administrativa e índice remuneração mais alto do que a média local (Shore, 2000).

Segundo Veríssimo (2001b) duas destas creches são de qualidade destacada. Além disto, pesquisa realizada por Sekkel (1998) corrobora o mesmo no que diz respeito a uma delas. Shibayama (2001) fez um estudo na mesma creche e concluiu que as educadoras/cuidadoras percebem o quanto $\mathrm{o}$ ambiente $\mathrm{e} o$ ato de conversar/escutar com as crianças é importante para o desenvolvimento delas. 
As 3 creches (A, B e C) estimulam a educação continuada dos educadores promovendo reuniões periódicas e discussões. Apresentam no quadro de funcionários os seguintes profissionais: educadoras, psicóloga, pedagoga, enfermeira (em duas das creches), auxiliares de enfermagem (no caso de 2 creches), funcionários administrativos, cozinheiros, técnico em nutrição e funcionários de limpeza.

No que diz respeito às educadoras, que ficam mais tempo no cuidado direto das crianças, sabe-se que nas creches A e B cumprem carga horária diária de 6 horas e na $\mathrm{C}$ de 8.

No quadro 1 pode-se verificar que nas três creches a maior parte das educadoras possuem nível superior completo.

Quadro 1. Características das creches e escolaridade das educadoras. São Paulo, 2001-2004.

\begin{tabular}{|c|c|c|c|c|c|c|}
\hline \multirow[t]{2}{*}{ Creche } & \multirow{2}{*}{$\begin{array}{l}\text { Número de } \\
\text { crianças } \\
\text { atendidas }\end{array}$} & \multirow{2}{*}{$\begin{array}{c}\text { Número } \\
\text { total de } \\
\text { educadoras }\end{array}$} & \multirow{2}{*}{$\begin{array}{l}\text { Proporção } \\
\text { criança/ } \\
\text { educadora }\end{array}$} & \multicolumn{3}{|c|}{ Escolaridade das educadoras } \\
\hline & & & & Grau & $\mathrm{N}^{\mathrm{O}}$ & $\%$ \\
\hline A & 250 & 44 & 5,68 & $\begin{array}{l}\text { Superior completo } \\
\text { Superior incompleto } \\
2^{\circ} \text { Grau completo }\end{array}$ & $\begin{array}{l}24 \\
08 \\
12\end{array}$ & $\begin{array}{l}54,55 \\
18,18 \\
27,27\end{array}$ \\
\hline B & 103 & 25 & 4,12 & $\begin{array}{l}\text { Superior completo } \\
\text { Superior incompleto } \\
2^{\circ} \text { Grau completo }\end{array}$ & $\begin{array}{l}15 \\
02 \\
08\end{array}$ & $\begin{array}{c}60,00 \\
8,00 \\
32,00\end{array}$ \\
\hline $\mathrm{C}$ & 35 & 8 & 4,3 & $\begin{array}{l}\text { Superior incompleto } \\
2^{\circ} \text { Grau completo }\end{array}$ & $\begin{array}{l}06 \\
02\end{array}$ & $\begin{array}{l}75,00 \\
25,00\end{array}$ \\
\hline
\end{tabular}

O quadro 2 apresenta seu tempo de experiência profissional. Percebe-se que nas creches A e B a maioria das educadoras $(61,36 \%$ e $60 \%$ respectivamente) têm mais de 5 anos de experiência em creches e na creche $\mathrm{C}$ apenas $25 \%$ das educadoras. 
Quadro 2. Tempo de experiência das educadoras em creches. São Paulo, 2004.

\begin{tabular}{|c|c|c|c|}
\hline $\begin{array}{c}\text { Tempo de } \\
\text { experiência em } \\
\text { creches }\end{array}$ & $\begin{array}{c}\text { Número de } \\
\text { educadoras } \\
\text { Creche A }\end{array}$ & $\begin{array}{c}\text { Número de } \\
\text { educadoras } \\
\text { Creche B }\end{array}$ & $\begin{array}{c}\text { Número de } \\
\text { educadoras } \\
\text { Creche C }\end{array}$ \\
\hline 8 meses -5 anos & 17 & 10 & 6 \\
\hline $5-9$ anos & 04 & 3 & 0 \\
\hline $9-13$ anos & 11 & 4 & 0 \\
\hline $13-17$ anos & 09 & 8 & 0 \\
\hline $17-22$ anos & 03 & 0 & 0 \\
\hline
\end{tabular}

\subsection{Formação do grupo de estudo}

Os critérios de inclusão para formação do grupo amostral de crianças obtido por conveniência (Berquó, Souza, Gotlieb, 2002) foram:

idade gestacional conhecida (para menores de 2 anos),

ausência de qualquer malformação congênita,

não ser estrangeira. Vale ressaltar que as instituições deste estudo são universitárias e recebem estudantes de outros países.

nunca ter freqüentado outra creche, uma vez que se pretendia, na medida no possível, conhecer a possível influência das instituições e neste caso, elas teriam que ser instituições conhecidas. Isto se deve ao fato de que em nosso país as formas de atendimentos em creches são muito díspares.

\subsection{Teste de Triagem de Desenvolvimento de Denver II (TTDD II)}

Figueiras, Souza e Pedromônico (2003) estabeleceram uma tipologia para o acompanhamento do desenvolvimento que compreende quatro categorias. De acordo com esta, nossa proposta está mais próxima de um "screening" de desenvolvimento: “processo de checagem metodológica do desenvolvimento de crianças aparentemente 
normais, com o objetivo de se identificar crianças de alto risco para problemas de desenvolvimento, utilizando-se a aplicação de testes ou escalas, exames e outros procedimentos". Para acompanhar o desenvolvimento, o uso de instrumentos de triagem é interessante porque agrupam marcos e as idades em que milhares de crianças o realizam.

Para tal usou-se o Teste de Triagem de Desenvolvimento de Denver II (TTDD II) (Anexo 1), aplicável a crianças desde o nascimento até 6 anos de idade incompletos (Frankenburg et al., 1992a).

O Teste de Triagem de Desenvolvimento de Denver (TTDD) foi elaborado a primeira vez em 1967 por um grupo de pediatras norte-americanos e desde então vem sendo utilizado em muitos países. O teste passou por uma reformulação em 1990 (Frankenburg et al., 1992a), para o que foi feita avaliação de 2000 crianças de diversos estados americanos, residentes em área urbana e rural, de diferentes níveis sócio-econômicos e várias etnias. A partir deste estudo, eliminaram-se itens de administração e interpretação mais difíceis e foram elaborados outros (Frankenburg et al., 1992b).

Assim obteve-se o Teste de Triagem de Desenvolvimento de Denver II (TTDD II), versão que consta de 125 itens distribuídos em 4 áreas do desenvolvimento: pessoal-social (aspectos da socialização da criança dentro e fora do ambiente familiar), motor fino (coordenação olho/mão, manipulação de pequenos objetos), linguagem (produção de som, capacidade de reconhecer, entender e usar a linguagem) e motor grosso (controle motor corporal como sentar e andar).

Alguns itens são observados diretamente, outros obtidos por indagação aos pais ou cuidadores que conheçam bem a criança. 
Segundo o autor principal do teste, este instrumento não foi criado para diagnosticar atrasos no desenvolvimento (Frankenburg, 1992), e sim direcionar a atenção e o cuidado dos adultos para as crianças com riscos de problemas no seu desenvolvimento.

Através do TTDD II não é possível predizer como estará o desenvolvimento da criança depois de um período da avaliação (Frankenburg, 1994). Por exemplo, se hoje a criança está com problema na linguagem não se pode afirmar que daqui a 1 ano ela continuará com problemas. Por isso é importante fazer avaliação periodicamente. Segundo Brêtas, Cassula e Reis (2001):

“Os dados obtidos através da aplicação são utilizados para determinar se a criança está progredindo como esperado para sua idade cronológica e maturidade, assim como o planejamento de estratégias de atuação junto à criança e na orientação aos pais para sua participação na intervenção com a criança e esclarecimentos sobre seu futuro desenvolvimento. Tais dados também possibilitam o acompanhamento do desenvolvimento da criança e sua comparação em idades posteriores, podendo sugerir a necessidade de um exame pormenorizado, com conseqüente encaminhamento a profissionais especializados".

\subsubsection{Aplicação do TTDD-II}

Para a aplicação do teste, são necessários os seguintes materiais: 1 pompom vermelho de 10 centímetros de diâmetro; 1 chocalho de cabo estreito; 1 sino; 1 saco de balas de goma, tipo "jujuba"; 10 cubos de madeira de 2,5 cm nas cores vermelho, amarelo, azul, verde e laranja; 1 caneca; 1 boneca de plástico com mamadeira; 1 bola de tênis; 1 lápis vermelho; folha de sulfite A4; 1 folha contendo cinco desenhos (Anexo 2); 1 folha com figuras geométricas (Anexo 3) e folha de aplicação do teste 
(Anexo 1). Além disto, criamos um formulário para avaliar as condições da criança (Anexo 4).

Caso a criança a ser avaliada tivesse menos de 2 anos de idade era indispensável conhecer a idade gestacional e corrigi-la no caso de pré-termo (Frankenburg et al., 1992a). Os autores determinam este ajuste para os que nasceram mais que 2 semanas antes da data esperada para o parto, porém, não deixam evidente o que consideram data esperada. Fizemos o ajuste para as crianças que nasceram com idade gestacional inferior a 37 semanas. Ou seja, uma criança que nasceu de 36 semanas, na primeira avaliação sua idade era 1 ano e 7 dias, subtraindo 1 mês sua idade ajustada foi de 11 meses e 7 dias, a que consideramos na avaliação.

Cada criança foi triada cinco vezes sucessivamente. Ao fazê-lo considerávamos alguns fatores de exclusão temporários que poderiam afetar o resultado como: sono, fadiga, adoecimento, febre, ou medo. Caso a criança apresentasse algum, esperava-se até que fosse superado, o que podia, eventualmente, demorar vários dias. Além disto, durante a aplicação, o teste é interrompido caso a criança se canse ou quando a criança precise participar de alguma atividade prevista na creche, por exemplo, jantar. Assim, a aplicação do TTDD II pode ser eventualmente muito demorada (Rezende et al., 2003).

No que diz respeito à aplicação do TTDD II propriamente dito, calcula-se previamente a idade da criança em anos, meses e dias. Após, traça-se no formulário (Frankenburg et al., 1999) uma linha vertical correspondente à idade. São aplicados os itens cortados pela linha, bem como outros 3 totalmente à esquerda, em cada área do desenvolvimento, a fim de detectar se há algum atraso. 
Cada item é representado por uma barra, plotada no eixo do tempo, indicando a idade em que o comportamento começa a ser realizado até a idade em que deve ser alcançado pela maior parte das crianças daquela idade. A barra é graficamente apresentada como um retângulo branco para significar a fase de aquisição do comportamento, contígua a um retângulo escuro para representar a fase em que 75 a $90 \%$ das crianças apresentam o comportamento. Cada um destes itens é interpretado como:

Avançado: a criança passa em um item à direita da linha da idade.

Normal: quando a criança realiza um item que está sendo cortado pela linha de sua idade, ou quando a criança falha, ou recusa-se a realizar um item que está completamente à direita da linha da idade.

Cautela: quando a criança falha ou recusa-se a realizar o item no qual a linha da idade cruza entre 75 e $90 \%$.

Atraso: quando a criança falha ou recusa-se a realizar um item que está totalmente à esquerda da linha da idade.

Itens não observados: não são considerados na interpretação.

Após interpretar cada item ou comportamento, o teste "global" pode ter três tipos de resultados:

Normal: quando não há atrasos e no máximo 1 cautela.

Suspeito: quando há 2 ou mais cautelas e/ou 1 ou mais atrasos

Não testável: recusa-se a realizar 1 ou mais itens à esquerda da linha da idade ou mais de 1 item no qual a linha da idade cruza entre 75 e $90 \%$.

Nesta pesquisa o teste foi aplicado por inteiro, feito a interpretação geral e logo em seguida, foi interpretada a área de linguagem isoladamente. Ressaltamos que 
esta interpretação da área isoladamente não é prevista pelos autores do TTDD II e que a realizamos tendo claro que se trata de um corte artificial, embora necessário para que realizemos a análise das informações.

A área de linguagem foi considerada "adequada" quando a criança não apresentou cautelas e/ou atrasos, e "risco" quando apresentou cautela e/ou atraso.

\subsection{Cuidados éticos}

O projeto foi aprovado pelo Comitê de Ética da Escola de Enfermagem da USP de acordo com os pareceres 136/2001, 248/2002 e 397/2004 (Anexos 5, 6 e 7). O diretor de cada instituição permitiu a pesquisa e o mesmo fizeram os pais. Estes foram informados a respeito da pesquisa e lhes foi solicita a autorização de participação. Caso concordassem, assinavam o Termo de Consentimento Livre e Esclarecido (Anexo 8).

Crianças eventualmente identificadas com atrasos e/ou cautelas foram reavaliadas e as respectivas situações trabalhadas com a direção das instituições e/ou familiares, conforme a necessidade.

Além disto, houve a intenção de afastar as variáveis que podem interferir no resultado da aplicação do TTDD II, sendo necessários alguns cuidados em todas as avaliações e outros somente na primeira avaliação.

De um modo geral realizamos uma reavaliação, após 1 a 2 semanas, em todas as crianças que apresentaram como resultado a classificação suspeito (mais de uma cautela e/ou 1 ou mais atrasos) seguindo as orientações dos autores do teste (Frankenburg, et al., 1992a). Além disto, cada criança foi levada para uma sala que 
ela já conhecia, para separá-la das outras crianças que poderiam influenciar no seu desempenho do teste. Os materiais eram mostrados aos poucos e recolhidos após seu uso com o objetivo de não prejudicar a avaliação das outras áreas. Além disto, o teste era aplicado em forma de brincadeira.

Anteriormente ao início da primeira avaliação, a pesquisadora permaneceu alguns períodos com cada grupo para as crianças se acostumarem com a sua presença. Isto contribuiu na abordagem da maioria das crianças, porém em alguns casos houve a necessidade da presença da educadora durante a realização do teste, tanto na primeira como na segunda avaliação. Deste modo, o tempo necessário para aplicação aumentou muito. A afirmação de que o tempo necessário para aplicação é de 15 a 20 minutos (O’Hara, Church, Blatt, 1998) não se aplica à avaliação dessas crianças. Cabe ressaltar que o teste de cada criança não foi realizado em partes, ou cada área do desenvolvimento testada em dias diferentes. Nos casos que a criança realizou somente alguns itens no primeiro encontro e se recusou a terminar o teste, na próxima tentativa todos eles foram administrados novamente.

Nas três creches, as educadoras são fixas, isto é, permanecem sempre com as mesmas crianças. Isto é feito com o propósito de favorecer a ligação afetiva entre criança e educador, condição útil para o favorecimento do desenvolvimento das crianças. Assim, as educadoras tornam-se o que Bowlby (1984) nomeia "cuidadores secundários" e exercem, em parte, o papel que caberia à mãe (ou ao cuidador primário) durante a aplicação do TTDD II.

Nas duas últimas avaliações todas as crianças reconheceram a pesquisadora, iniciavam a interação e perguntavam se iam brincar novamente. Algumas perguntaram onde estavam os blocos coloridos e a folha dos animais. Muitas delas 
pediram para a pesquisadora contar estórias, o que foi possível realizar antes ou após aplicação do teste.

\subsection{Análise dos dados}

Os dados foram trabalhados por meio de testes estatísticos não paramétricos, uma vez que não era possível assegurar sua distribuição gaussiana. O nível de significância adotado foi sempre de $5 \%$.

Para comparações entre dados nominais não emparelhados foram utilizados os testes Qui-Quadrado ou Exato de Fisher, quando necessário, isto é, para amostras menores.

Para tabelas diferentes de $2 \times 2$, quando houve diferença entre os grupos, foi feita a análise de resíduo para a identificação de quais pares de categorias correspondiam a um valor acima do esperado, ou seja, quais categorias se diferenciavam entre os grupos apresentando associação. Nesta análise, valor do resíduo padronizado (Zres) acima de 1,96, indica associação estatística na casela, sempre a um nível de significância de 5\%.

O Teste de Dunn foi utilizado para comparações múltiplas entre os resultados. 


\section{RESULTADOS}

\subsection{Caracterização dos participantes}

O nível sócio-econômico foi avaliado segundo instrumento (anexo 9) para verificação do nível de pobreza de populações urbanas (Issler, Giugliani, 1997) e é composto por 13 itens, compreendendo: constituição da família, escolaridade e atividade dos pais, condições de moradia e posse de bens. Cada um dos itens é pontuado e a soma estabelece o nível de pobreza: miséria (até 17,3 pontos), baixo inferior (17,3 a 34,6 pontos) e baixo superior (34,6 a 52,0 pontos).

No grupo ora estudado todas as famílias tiveram pontuação entre 45 e 52 . Assim, todas são da categoria baixa superior.

Em outro estudo realizado na creche B, em 2002 e 2003, (Veríssimo, 2004) verificou-se que 22,5\% dos pais das crianças recebiam de 2,31 a 3,84 salários mínimos (SM), sendo estes os que recebiam os salários mais baixos. Além disso, $49,7 \%$ dos pais ganhavam 3,85 a 5,76 SM. Outros $27,8 \%$ recebiam de 5,77 a 26,91 SM. Estes valores não compreenderam outros tipos de subsídios financeiros tais como o transporte e as refeições, nem os salários dos cônjuges. A média destes salários todos era 7,60 SM, portanto, melhor do que o salário médio na região metropolitana da cidade de São Paulo no mesmo período, que era 4,28 SM (Rezende, Beteli, Santos, 2005b).

Assim, a condição sócio-econômica das famílias das crianças deste trabalho é diferenciada. 
No que diz respeito às crianças, quando a coleta foi iniciada, em 2001, havia 55 recém matriculadas nas três creches selecionadas para o estudo. Porém, tivemos perdas paulatinas ao longo dos cinco momentos em que o TTDD II foi aplicado (Quadro 3).

Quadro 3. Formação dos grupos amostrais constituídos de crianças que freqüentam 3 creches triadas de acordo com o TTDD II. São Paulo, 2001-2004.

\begin{tabular}{|c|c|c|c|}
\hline $\begin{array}{c}\text { Momento } \\
\text { da } \\
\text { pesquisa }\end{array}$ & $\begin{array}{c}\text { Total } \\
\text { de } \\
\text { crianças }\end{array}$ & $\begin{array}{c}\text { Crianças } \\
\text { que não } \\
\text { participaram }\end{array}$ & $\begin{array}{c}\text { Crianças } \\
\text { efetivamente } \\
\text { triadas }\end{array}$ \\
\hline $1^{\text {a }}$ avaliação & 55 & 22 & 33 \\
\hline $2^{\text {a }}$ avaliação & 33 & 0 & 33 \\
\hline $3^{\text {a }}$ avaliação & 33 & 3 & 30 \\
\hline $4^{\text {a }}$ avaliação & 30 & 2 & 28 \\
\hline $5^{\text {a }}$ avaliação & 28 & 2 & 26 \\
\hline
\end{tabular}

No quadro 4 são apresentados os motivos da não participação das crianças ao longo das 5 avaliações. Este é um dado importante, inclusive para pesquisas futuras, pois pode ajudar o pesquisador a estimar com maior precisão sua porcentagem de perdas.

Chama a atenção o número de perdas por ocasião da primeira avaliação. No entanto, esta foi atípica, pois em uma das instituições (creche A) não tivemos autorização para conversar diretamente com os familiares. Apenas nesta instituição houve famílias que não autorizaram a participação das crianças. A partir daí as perdas se deram somente por ausência, recusa ou interrupção da freqüência da criança à creche. 
Quadro 4. Motivos pelos quais crianças que freqüentam 3 creches não foram triadas segundo o TTDD II. São Paulo 2001-2004.

\begin{tabular}{|c|c|c|}
\hline $\begin{array}{l}\text { Momento da } \\
\text { pesquisa }\end{array}$ & Motivo & Freqüiência \\
\hline \multirow{10}{*}{$\begin{array}{l}\text { Antes da } 1^{\mathrm{a}} \text {. } \\
\text { avaliação }\end{array}$} & Família não autorizou a avaliação & 9 \\
\hline & $\begin{array}{l}\text { Criança sempre ausente nos períodos definidos para } \\
\text { aplicação do teste }\end{array}$ & 2 \\
\hline & Criança recusou-se a ser avaliada & 2 \\
\hline & $\begin{array}{l}\text { Impossibilidade de contato com os pais a fim de } \\
\text { completar itens da avaliação }\end{array}$ & 2 \\
\hline & Malformação congênita & 1 \\
\hline & Desconhecimento da idade gestacional & 1 \\
\hline & Criança estrangeira recém-chegada ao Brasil & 1 \\
\hline & $\begin{array}{c}\text { Criança abandonou a creche após poucos dias de } \\
\text { freqüência }\end{array}$ & 1 \\
\hline & $\begin{array}{l}\text { Criança sempre ausente nos períodos definidos para } \\
\text { aplicação do teste }\end{array}$ & 2 \\
\hline & Criança parou de freqüentar a creche & 1 \\
\hline \multirow{2}{*}{$\begin{array}{l}\text { Antes da } 3^{\mathrm{a}} \\
\text { avaliação }\end{array}$} & Criança recusou-se a ser avaliada & 2 \\
\hline & Criança parou de freqüentar a creche & 1 \\
\hline $\begin{array}{c}\text { Antes da } 4^{\mathrm{a}} \\
\text { avaliação }\end{array}$ & Criança parou de freqüentar a creche & 2 \\
\hline $\begin{array}{l}\text { Antes da } 5^{\text {a }} \\
\text { avaliação }\end{array}$ & Criança parou de freqüentar a creche & 2 \\
\hline
\end{tabular}

O quadro 5, a seguir, apresenta as características etárias das crianças das três creches triadas ao longo do período de 2001 a 2004. 
Quadro 5. Características das avaliações das crianças atendidas nas 3 creches.

São Paulo, 2001-2004.

\begin{tabular}{|c|c|c|c|}
\hline Avaliação & $\begin{array}{c}\text { Faixa etária das } \\
\text { crianças }\end{array}$ & $\begin{array}{c}\text { Tempo de permanência } \\
\text { da criança na creche no } \\
\text { momento da triagem }\end{array}$ & $\begin{array}{l}\text { Momento } \\
\text { da } \\
\text { triagem }\end{array}$ \\
\hline $1^{\mathrm{a}}$ & $\begin{array}{c}4 \text { meses e } 23 \text { dias } \\
\text { até } \\
2 \text { anos } 4 \text { meses e } \\
12 \text { dias }\end{array}$ & 1 dia $\mid-5$ meses & Junho de 2001 \\
\hline $2^{a}$ & $\begin{array}{c}10 \text { meses e } 20 \text { dias } \\
\text { até } \\
2 \text { anos } 10 \text { meses e } \\
28 \text { dias }\end{array}$ & 5 meses $\vdash 10$ meses & Dezembro de 2001 \\
\hline $3^{a}$ & $\begin{array}{c}2 \text { anos e } 15 \text { dias } \\
\text { até } \\
4 \text { anos }\end{array}$ & 10 meses $\mid 24$ meses & $\begin{array}{l}\text { Dezembro de } 2002 \\
\text { a } \\
\text { Fevereiro de } 2003\end{array}$ \\
\hline $4^{a}$ & $\begin{array}{c}3 \text { anos e } 1 \text { mês } \\
\text { Até } \\
4 \text { anos e } 11 \text { meses }\end{array}$ & 24 meses $\mid 39$ meses & Dezembro de 2003 \\
\hline $5^{a}$ & $\begin{array}{c}3 \text { anos } 11 \text { meses e } \\
3 \text { dias } \\
\text { até } \\
5 \text { anos } 7 \text { meses e } \\
11 \text { dias } \\
\end{array}$ & 39 meses $\mapsto 46$ meses & $\begin{array}{c}\text { Agosto de } 2004 \\
\text { a } \\
\text { Dezembro de } 2004\end{array}$ \\
\hline
\end{tabular}

Nos anexos 10 e 11 é possível visualizar todas as características das crianças e resultados detalhados do grupo

\subsection{Resultados do TTDD II}

\subsubsection{Avaliação global}

Primeiramente os resultados obtidos nas 3 instituições foram contrastados com a finalidade de verificar mais uma vez se os grupos eram similares. Este cuidado já havia sido tomado anteriormente quando da seleção das três instituições 
participantes da pesquisa. Segundo o Teste exato de Fisher, cujo resultado não foi significante, as três instituições não diferiram entre si.

Tabela 1 - Resultados globais do TTDD-II das crianças das três instituições. São Paulo, 2001-2004.

\begin{tabular}{ccccccc}
\hline Creche & \multicolumn{2}{c}{ Resultado normal } & \multicolumn{2}{c}{ Resultado suspeito } & \multicolumn{2}{c}{ Total } \\
& $\mathrm{N}$ & $\%$ & $\mathrm{~N}$ & $\%$ & $\mathrm{~N}$ & $\%$ \\
\hline A & 60 & 80,00 & 15 & 20,00 & 75 & 100,00 \\
B & 33 & 78,57 & 9 & 21,43 & 42 & 100,00 \\
C & 27 & 81,80 & 6 & 18,20 & 33 & 100,00 \\
\hline Total & 120 & 80,00 & 30 & 20,00 & 150 & 100,00
\end{tabular}

Teste exato de Fisher: 0,964

Assim, os resultados passaram a ser trabalhados como sendo de uma única instituição.

No que diz respeito ao sexo, os resultados globais do TTDD II não mostravam relação (Teste exato de Fisher não significante).

Tabela 2 - Resultados do TTDD II, de acordo com o sexo, aplicado à crianças de três creches. São Paulo, 2001-2004.

\begin{tabular}{ccccccc}
\hline Resultados do TTDD-II & \multicolumn{2}{c}{ Sexo masculino } & \multicolumn{2}{c}{ Sexo feminino } & \multicolumn{2}{c}{ Total } \\
& $\mathrm{N}$ & $\%$ & $\mathrm{~N}$ & $\%$ & $\mathrm{~N}$ & $\%$ \\
\hline Normal & 65 & 54,17 & 55 & 45,83 & 120 & 100,00 \\
Suspeito & 19 & 63,33 & 11 & 36,67 & 30 & 100,00 \\
\hline Total & 84 & 56,00 & 66 & 44,00 & 150 & 100,00 \\
\hline
\end{tabular}

Teste exato de Fisher: 0,243

A seguir apresentaremos os resultados obtidos pelas crianças a partir da aplicação do TTDD II. Para tal vamos seguir a seguinte ordem: primeiramente apresentaremos os resultados globais e após os específicos para a área de linguagem. 
Cada um destes aspectos será apresentado de dois modos: resultados das avaliações sucessivas $\left(1^{\mathrm{a}}\right.$ a $\left.5^{\mathrm{a}}\right)$ e, após, resultados segundo as idades agrupadas, independentemente da ordem de avaliação.

\subsubsection{Segundo ordem temporal das triagens}

Assim, passamos a apresentar os resultados globais segundo a ordem das 5 avaliações.

Podemos observar que houve diferença ao longo do tempo (Teste de Friedmann, $\left.\mathrm{p}=0,006^{*}\right)$. Para identificar quais momentos se diferenciaram entre si, foram feitas comparações múltiplas (comparações dois a dois momentos) através do teste de Dunn. Os momentos que são significantemente diferentes são as segunda e terceira avaliações ao serem comparadas à primeira e os resultados melhoraram na medida do avanço do tempo. Assim, houve melhora importante dos resultados após a primeira avaliação.

Tabela 3 - Resultados do TTDD-II das crianças que freqüentam três creches. São Paulo, 2001-2004.

\begin{tabular}{|c|c|c|c|c|c|c|c|c|c|c|c|}
\hline \multirow[t]{2}{*}{$\begin{array}{c}\text { Resultados } \\
\text { dos testes }\end{array}$} & \multicolumn{2}{|c|}{$\begin{array}{c}\text { 1a. } \\
\text { avaliação }\end{array}$} & \multicolumn{2}{|c|}{$\begin{array}{c}2^{\mathrm{a}} \text {. } \\
\text { avaliação }\end{array}$} & \multicolumn{2}{|c|}{$\begin{array}{c}3^{\mathrm{a}} . \\
\text { avaliação }\end{array}$} & \multicolumn{2}{|c|}{$\begin{array}{c}4^{\mathrm{a}} . \\
\text { avaliação }\end{array}$} & \multicolumn{2}{|c|}{$\begin{array}{c}5^{\mathrm{a}} \cdot \\
\text { avaliação }\end{array}$} & Tota \\
\hline & $\mathrm{N}$ & $\%$ & $\mathrm{~N}$ & $\%$ & $\mathrm{~N}$ & $\%$ & $\mathrm{~N}$ & $\%$ & $\mathrm{~N}$ & $\%$ & $\mathrm{~N}$ \\
\hline Normal & 21 & 63,6 & 31 & 93,9 & 26 & 86,7 & 21 & 75,0 & 21 & 80,8 & 120 \\
\hline Suspeito & 12 & 36,4 & 2 & 6,1 & 4 & 13,3 & 7 & 25,0 & 5 & 19,2 & 30 \\
\hline Total & 33 & 100,0 & 33 & 100,0 & 30 & 100,0 & 28 & 100,0 & 26 & 100,0 & 150 \\
\hline
\end{tabular}




\subsubsection{Segundo as idades das crianças}

No caso das crianças cujas idades variaram de $0 \mathrm{a} \leq 1$ ano (Tabela 4) não houve diferença significante quando divididas em 2 grupos dicotomizados em: freqüência à creche de $\geq 1$ dia a $<5$ meses, e, $\geq 5$ meses a $<10$ meses. Isto é, é indiferente o tempo de freqüência quando se leva em conta a faixa etária de 0 a $\leq 1$ ano de idade.

Tabela 4 - Resultados do TTDD II de acordo com o tempo que as crianças de 0 a $\leq 1$ ano de idade freqüentaram a creche. São Paulo, 2001-2004.

\begin{tabular}{lcccc}
\hline \multirow{2}{*}{ Tempo de freqüência à creche } & \multicolumn{4}{c}{ Resultado Global } \\
& $\mathrm{N}$ & $\%$ & $\mathrm{~N}$ & $\%$ \\
\hline 1 dia -5 meses & 3 & 75,00 & 8 & 72,70 \\
5 meses -10 meses & 1 & 25,00 & 3 & 27,30 \\
\hline Total & 4 & 100,00 & 11 & 100,00 \\
\hline
\end{tabular}

Teste Qui-Quadrado

p-valor $>0,999$

Podemos notar que há diferença significante no caso de crianças da faixa etária de $>1$ a $\leq 2$ anos de idade (Tabela 5 ), sugerindo que a creche pode ter influído na melhora destes resultados. Ressaltamos que a freqüência à instituição foi dicotomizada de modo igual ao da faixa etária anterior.

No entanto, do mesmo modo que se fez a ressalva anterior, não é possível delimitar as esferas de influência de creche e família, respectivamente, uma vez que este estudo não foi desenhado com esta finalidade. 
Tabela 5 - Resultados do TTDD II de acordo com o tempo que as crianças de $>1$ a $\leq 2$ anos de idade freqüentavam a creche. São Paulo, 2001-2004.

\begin{tabular}{lcccc}
\hline \multirow{2}{*}{ Tempo de freqüência à creche } & \multicolumn{4}{c}{ Resultado Global } \\
& $\mathrm{N}$ & $\%$ & $\mathrm{~N}$ & $\%$ \\
\hline 1 dia -5 meses & 8 & 100,00 & 8 & 28,60 \\
5 F 10 meses & 0 & 00,00 & 20 & 71,40 \\
\hline Total & 8 & 100,00 & 28 & 100,00 \\
\hline
\end{tabular}

Teste Qui-Quadrado p-valor $=0,000^{*}$

No caso das crianças de $>2$ a $\leq 3$ anos (Tabela 6), os períodos de permanência nas creches foram divididos em três: freqüência de $\geq 1$ dia a $<5$ meses, de $\geq 5$ meses a $<10$ meses, e, $\geq 10$ meses a $<24$ meses. Não houve diferença significante entre os períodos.

Tabela 6 - Resultados do TTDD II de acordo com o tempo que as crianças de $>2$ a $\leq 3$ anos de idade freqüentaram a creche. São Paulo, 2001-2004.

\begin{tabular}{lcccc}
\hline \multirow{2}{*}{ Tempo de freqüência à creche } & \multicolumn{4}{c}{ Resultado Global } \\
& $\mathrm{N}$ & $\%$ & $\mathrm{~N}$ & $\%$ \\
\hline 1 dia -5 meses & 1 & 33,30 & 5 & 15,60 \\
5 meses -10 meses & 1 & 33,30 & 8 & 25,00 \\
10 meses -24 meses & 1 & 33,30 & 19 & 59,40 \\
\hline Total & 3 & 100,00 & 32 & 100,00 \\
\hline
\end{tabular}

Teste Qui-Quadrado

$\mathrm{p}$-valor $=0,637$

No caso das crianças de $>3$ a $\leq 4$ anos (Tabela 7), os períodos de freqüência foram divididos em: de $\geq 10$ meses a $<24$ meses, de $\geq 24$ meses a $<39$ meses, e, de $\geq 39$ meses a <46 meses. Há diferença estatística significante, perceptível ao se 
observar o valor do resíduo. A diferença se dá, no grupo com avaliações "normal" que freqüentam a creche em um período de 24 a 39 meses, e sugere que melhores resultados acontecem a medida que a freqüência aumenta. No entanto, esta melhora relativa desaparece quando se considera freqüência maior que 39 meses.

Tabela 7 - Resultados do TTDD II de acordo com o tempo que as crianças de $>3$ a $\leq$ 4 anos de idade freqüentaram a creche. São Paulo, 2001-2004.

\begin{tabular}{lcccc}
\hline \multirow{2}{*}{ Tempo de freqüência à creche } & \multicolumn{4}{c}{ Resultado Global } \\
& $\mathrm{N}$ & $\%$ & $\mathrm{~N}$ & $\%$ \\
\hline 10 meses $\vdash$ - 24 meses & 3 & 60,00 & 7 & 28,00 \\
24 meses -39 meses & 0 & 0,00 & 15 & $60,00(1)$ \\
39 meses H 46 meses & 2 & 40,00 & 3 & 12,00 \\
\hline Total & 5 & 100,00 & 25 & 100,00 \\
\hline
\end{tabular}

Teste Qui-Quadrado

p-valor $=0,044(1) \mathrm{z}$-res $=2,4$

No caso das crianças de $>4$ a $\leq 6$ anos (Tabela 8 ), os períodos de frequiência foram divididos em: de $\geq 24$ meses a $<39$ meses, e, de $\geq 39$ meses a $<46$ meses. Não houve diferença estatística significante estes os grupos estudados.

Tabela 8 - Resultados do TTDD II de acordo com o tempo que as crianças de $>4$ a $\leq 6$ anos de idade freqüentaram a creche. São Paulo, 2001-2004.

\begin{tabular}{lcccc}
\hline \multirow{2}{*}{ Tempo de freqüência à creche } & \multicolumn{4}{c}{ Resultado Global } \\
& $\mathrm{N}$ & $\%$ & $\mathrm{~N}$ & normal \\
\hline 24 meses $\vdash$ - 39 meses & 6 & 60,00 & 5 & 20,80 \\
39 meses H 46 meses & 4 & 40,00 & 19 & 79,20 \\
\hline Total & 10 & 100,00 & 24 & 100,00 \\
\hline
\end{tabular}

Teste Qui-Quadrado

$\mathrm{p}$-valor $=0,026$ 


\subsection{2 Área de linguagem}

Os resultados específicos da área de linguagem não foram previstos pelos autores do teste, tendo sido usados por necessidade de análise. Como explicado anteriormente, a área de linguagem foi considerada "adequada" quando a criança não apresentou cautelas e/ou atrasos, e "risco" quando apresentou cautela e/ou atraso.

Ao se analisar os resultados de acordo com a instituição (Tabela 9), obteve-se o mesmo que a análise realizada com os resultados globais.

Tabela 9 - Resultados da área de linguagem de acordo com a instituição. São Paulo, 2001-2004.

\begin{tabular}{ccccccc}
\hline Creche & \multicolumn{2}{c}{ Adequada } & \multicolumn{2}{c}{ Cautela ou atraso } & \multicolumn{2}{c}{ Total } \\
& $\mathrm{N}$ & $\%$ & $\mathrm{~N}$ & $\%$ & $\mathrm{~N}$ & $\%$ \\
\hline A & 61 & 81,30 & 14 & 18,70 & 75 & 100,00 \\
B & 33 & 78,60 & 9 & 21,40 & 42 & 100,00 \\
C & 23 & 69,70 & 10 & 30,30 & 33 & 100,00 \\
\hline Total & 117 & 78,00 & 33 & 22,00 & 150 & 100,00 \\
\hline
\end{tabular}

Teste exato de Fisher: 0,419

Ao se analisar o desempenho de acordo com o sexo, o resultado obtido não foi significante (Tabela 10).

Tabela 10 - Resultados da área de linguagem do TTDD II, de acordo com o sexo, aplicado às crianças de três creches. São Paulo, 2001-2004.

\begin{tabular}{cccccccc}
\hline Avaliações & \multicolumn{2}{c}{ Sexo masculino } & \multicolumn{2}{c}{ Sexo feminino } & \multicolumn{2}{c}{ Total } \\
& $\mathrm{N}$ & $\%$ & $\mathrm{~N}$ & $\%$ & $\mathrm{~N}$ & $\%$ \\
\hline Adequada & 65 & 55,55 & 52 & 44,45 & 117 & 100,00 \\
Cautela ou atraso & 19 & 57,58 & 14 & 42,42 & 33 & 100,00 \\
\hline Total & 84 & 56,00 & 66 & 44,00 & 150 & 100,00 \\
\hline
\end{tabular}

Teste exato de Fisher: 0,499 


\subsubsection{Segundo ordem temporal das triagens}

A análise dos resultados da área de linguagem ao longo das cinco avaliações percebe-se que não houve diferença significante, isto é, os resultados permanecem similares ao longo dos cinco momentos, diferente do que foi constatado na análise global do teste.

Tabela 11 - Resultados da área de linguagem de crianças que freqüentam creches, São Paulo, 2001-2004.

\begin{tabular}{|c|c|c|c|c|c|c|c|c|c|c|c|}
\hline & \multicolumn{2}{|c|}{$\begin{array}{c}\text { 1a } \\
\text { avaliação }\end{array}$} & \multicolumn{2}{|c|}{$\begin{array}{c}2 \mathrm{a} \\
\text { avaliação }\end{array}$} & \multicolumn{2}{|c|}{$\begin{array}{c}\text { 3a } \\
\text { avaliação }\end{array}$} & \multicolumn{2}{|c|}{$\begin{array}{c}\text { 4a } \\
\text { avaliação }\end{array}$} & \multicolumn{2}{|c|}{$\begin{array}{c}5 \mathrm{a} \\
\text { avaliação }\end{array}$} & \multirow{2}{*}{$\begin{array}{c}\text { Tota } \\
\mathrm{N}\end{array}$} \\
\hline & $\mathrm{N}$ & $\%$ & $\mathrm{~N}$ & $\%$ & $\mathrm{~N}$ & $\%$ & $\mathrm{~N}$ & $\%$ & $\mathrm{~N}$ & $\%$ & \\
\hline Adequado & 26 & 78,8 & 28 & 84,8 & 22 & 73,3 & 19 & 67,9 & 22 & 84,6 & 117 \\
\hline Risco & 7 & 21,2 & 5 & 15,2 & 8 & 26,7 & 9 & 32,1 & 4 & 15,4 & 33 \\
\hline Total & 33 & 100,0 & 33 & 100,0 & 30 & 100,0 & 28 & 100,0 & 26 & 100,0 & 150 \\
\hline
\end{tabular}

Teste de Friedmann

$\mathrm{p}$-valor $=0,728$

\subsubsection{Segundo as idades das crianças}

No caso das crianças cujas idades variaram de $0 \mathrm{a} \leq 1$ ano (Tabela 12) não houve diferença significante quando divididas em 2 grupos dicotomizados em: freqüência à creche de $\geq 1$ dia a $<5$ meses, e, $\geq 5$ meses a $<10$ meses. Isto é, é indiferente o tempo de freqüência quando se leva em conta a faixa etária de 0 a $\leq 1$ ano de idade. 
Tabela 12 - Resultados da área de linguagem de acordo com o tempo que as crianças de 0 a $\leq 1$ ano de idade freqüentaram a creche.

São Paulo, 2001-2004.

\begin{tabular}{lcccc}
\hline \multirow{2}{*}{ Tempo de freqüiência à creche } & \multicolumn{4}{c}{ Linguagem } \\
& $\mathrm{N}$ & $\%$ & $\mathrm{~N}$ & $\begin{array}{c}\text { adequado } \\
\%\end{array}$ \\
\hline 1 dia $\vdash 5$ meses & 2 & 50,00 & 9 & 81,80 \\
5 meses $P$ 10 meses & 2 & 50,00 & 2 & 18,20 \\
\hline Total & 4 & 100,00 & 11 & 100,00 \\
\hline
\end{tabular}

Teste Qui-Quadrado

p-valor $=0,218$

Também não há diferença significante no caso de crianças da faixa etária de $>1$ a $\leq 2$ anos de idade (Tabela 13). Ressaltamos que a freqüência à instituição foi dicotomizada de modo igual ao da faixa etária anterior.

Tabela 13 - Resultados da área de linguagem de acordo com o tempo que as crianças de $>1$ a $\leq 2$ anos de idade frequientaram a creche.

São Paulo, 2001-2004.

\begin{tabular}{lcccc}
\hline \multirow{2}{*}{ Tempo de freqüencia à creche } & \multicolumn{4}{c}{ Linguagem } \\
& $\mathrm{N}$ & $\%$ & $\mathrm{~N}$ & $\%$ \\
\hline 1 dia -5 meses & 5 & 62,50 & 11 & 39,30 \\
5 meses -10 meses & 3 & 37,50 & 17 & 60,70 \\
\hline \multirow{2}{*}{ Total } & 8 & 100,00 & 28 & 100,00 \\
\hline
\end{tabular}

Teste Qui-Quadrado $\mathrm{p}$-valor $=0,244$

Na faixa etária de $>2$ a $\leq 3$ (Tabela 14) o teste não foi analisável, uma vez que nos três períodos considerados $(\geq 1$ dia a $<5$ meses, de $\geq 5$ meses a $<10$ meses, e, $\geq 10$ meses a $<24$ meses) não havia crianças em risco. 
Tabela 14 - Resultados da área de linguagem de acordo com o tempo que as crianças de anos de idade frequientaram a creche.

São Paulo, 2001-2004.

\begin{tabular}{lcccc}
\hline \multirow{2}{*}{ Tempo de freqüência à creche } & \multicolumn{4}{c}{ Linguagem } \\
& $\mathrm{N}$ & $\%$ & $\mathrm{~N}$ & $\%$ \\
\hline 1 dia -5 meses & 0 & 0,00 & 6 & 17,10 \\
5 meses -10 meses & 0 & 0,00 & 9 & 25,70 \\
10 meses -24 meses & 0 & 0,00 & 20 & 57,10 \\
\hline Total & 0 & 0,00 & 35 & 100,00 \\
\hline
\end{tabular}

Teste Qui-Quadrado

Não analisável

$\mathrm{Na}$ faixa etária de $>3$ a $\leq 4$ anos (Tabela 15), o período de freqüência na instituição que diferiu significativamente foi o de 24 a 39 meses. Mesmo havendo melhora neste período, é importante notar que das 30 crianças nesta faixa etária 17 $(56,66 \%)$ apresentaram risco.

Tabela 15 - Resultados da área de linguagem de acordo com o tempo que as crianças de $>3 \mathrm{a} \leq 4$ anos de idade freqüentaram a creche.

São Paulo, 2001-2004.

\begin{tabular}{lcccc}
\hline \multirow{2}{*}{ Tempo de freqüência à creche } & \multicolumn{4}{c}{ Linguagem } \\
& $\mathrm{N}$ & $\%$ & $\mathrm{~N}$ & $\%$ \\
\hline 10 meses -24 meses & 8 & 47,10 & 2 & 15,40 \\
24 meses -39 meses & 5 & 29,40 & 10 & $76,90(1)$ \\
39 meses $H 46$ meses & 4 & 23,50 & 1 & 7,70 \\
\hline Total & 17 & & & \\
\hline
\end{tabular}

Teste Qui-Quadrado

p-valor $=0,036$ (1) z-res $=2,4$ 
No que diz respeito às crianças de $>4 \mathrm{a} \leq 6$ anos de idade não houve diferença dos resultados.

Tabela 16 - Resultados da área de linguagem de acordo com o tempo que as crianças de $>4$ a $\leq 6$ anos de idade freqüentaram a creche. São Paulo, 2001-2004.

\begin{tabular}{l|cccc}
\hline \multirow{2}{*}{ Tempo de freqüência à creche } & \multicolumn{4}{c}{ Linguagem } \\
& $\mathrm{N}$ & $\%$ & $\mathrm{~N}$ & $\%$ \\
\hline 24 meses -39 meses & 2 & 50,00 & 9 & 30,00 \\
39 meses $\mathrm{H}$ 46 meses & 2 & 50,00 & 21 & 70,00 \\
\hline Total & 4 & 100,00 & 30 & 100,00 \\
\hline
\end{tabular}

Teste Qui-Quadrado p-valor $=0,42$ 


\section{DISCUSSÃO}

Nossas crianças pertencem a um segmento da população privilegiada economicamente. Como poder econômico significa acesso a bens e às informações, é razoável supor que estas famílias tenham propiciado condições para o desenvolvimento destas crianças. Neste sentido valemo-nos da literatura para realizar comparações. Cabe ressaltar que foram encontrados poucos estudos brasileiros de triagem do desenvolvimento de crianças usando o TTDD II (Caon, Ries, 2003; Cunha, 2000; Halpern et al., 1996, 2000; Rezende, Costa, Pontes 2005c; Sousa, Siqueira, 2003). Além disto, todos são transversais, avaliaram diferentes faixas etárias, foram realizados em diversos locais como: creches públicas, privadas, nas casas das crianças e em ambulatório. Alguns utilizaram como fator de inclusão as crianças serem hígidas, outros não. Estas diferenças dificultam a comparação dos resultados.

No caso do estudo de Rezende, Costa e Pontes (2005) que usou a mesma metodologia, sabe-se que os resultados globais foram idênticos, isto é, não houve diferença significante na distribuição de resultados normais e suspeitos. Mesmo levando em conta que na população de 66 crianças do estudo supra citado a renda familiar per capita tenha sido consistentemente inferior a das famílias deste estudo. Assim, no sentido de resultado global do TTDD II não houve qualquer variação. No que tange à linguagem também não foi observada alteração significante entre as duas populações estudadas.

O estudo de Caon e Ries (2003) com crianças que freqüentavam creches públicas de Florianópolis, também se valeu da classificação do nível sócioeconômico de Issler, Giugliani (1997) e, tal como Rezende, Costa e Pontes (2005c) 
também resultou em classificação da população como pertencente à categoria baixasuperior. Este mesmo resultado obtido em populações diferentes no faz pensar que este instrumento não está sendo útil para detectar nuances que a renda permite fazer.

Além disto, estes últimos autores cruzaram os resultados do TTDD II tanto com a pontuação obtida para avaliação de pobreza, de acordo com Issler, Giugliani,(1997), quanto com a renda em salários mínimos sem haver resultado significante.

Outro fato a ser levado em conta, é que dificulta sobremaneira a comparação dos nossos resultados com os de Caon e Ries (2003), é que estes consideram atraso no resultado global de modo diferente do preconizado pelos autores do TTDD II, que, aliás foi o modo que usamos. Para resultado global os autores do TTDD II usam nomenclatura diferente: "normal" ou "suspeito" apenas reservam o termo "atraso" para avaliação de cada um dos itens isoladamente.

Souza, Siqueira (2003) realizaram um estudo transversal em creche filantrópica da cidade de São Paulo, em 2002, com 28 crianças. Não apresentaram avaliação das condições sócio-econômicas das crianças, mas considerando que a instituição é filantrópica, deve ser a mesma dos estudos de Rezende, Costa, Pontes (2003) e Caon, Ries (2003). Assim, não é possível verificar se os resultados estão relacionados ao nível sócio econômico das crianças.

Halpern e colaboradores (2000) analisaram o desenvolvimento neuropsicomotor de 1366 crianças, nascidas em Pelotas, com 1 ano de idade. Demonstraram relação de resultado global pior conforme diminuição da renda familiar. As crianças mais pobres apresentaram o dobro de falhas no TTDD II 
quando comparadas às de renda maior. Não analisaram separadamente os resultados da área de linguagem.

Sabe-se que a menor renda pode estar associada a dificuldades maiores de obter atendimento de saúde adequado, portanto, aumentam a possibilidade de baixo peso ao nascer, bem como acometimentos nas fases pré e pós natal e conseqüentes piores resultados em termos de desenvolvimento (Caon, Ries, 2003, Halpern et al., 1996,2000).

Assim, ao levarmos em conta as condições econômicas das famílias de nosso estudo vê-se que aparentemente não houve influência desta nos resultados obtidos. Estes foram semelhantes aos do trabalho de Rezende, Costa, Pontes (2005) que usou metodologia idêntica e foi realizado com crianças provenientes de famílias de condição econômica precária.

Assim a questão que se coloca é: até que ponto a influência econômica impacta nos resultados?

Pode talvez ser influência da idade das crianças avaliadas. O estudo de Halpern et al. (2000) foi realizado com crianças de 12 meses. O de Caon e Ries (2003) com crianças de 0 a 2 anos. O de Rezende, Costa, Pontes (2005c) crianças de 2 a 3 anos e o nosso, ora apresentado, abrange crianças de 0 a 6 anos incompletos.

Outra possibilidade diz respeito à influência da instituição na qual a criança está inserida, lembrando que a família é uma instituição. A qualidade desta instituição é determinante no produto almejado: uma criança com pleno desenvolvimento de suas potencialidades. No entanto é difícil determinar até que ponto influenciou respectivamente cada uma das esferas: a família e a creche. Famílias de melhores condições econômicas tendem evidentemente a buscar creches 
que ofereçam melhores condições para o desenvolvimento de suas crianças, guiandose, na maioria das vezes, por indicadores que intuitivamente parecem corretos (e são de fato, embora, não esgotem a questão da qualidade) tais como: instituições amplas, coloridas, com abundância de material pedagógico e maior número de educadores (Burchinal et al.1996; Burchinal et al., 2000).

Estudo de Peisner-Feinberg et al. (2001) realizado em várias cidades dos Estados Unidos, durante um período de 5 anos consecutivos, permitiu concluir que tanto famílias quanto creches de bom padrão de atendimento possibilitam a criança um bom desenvolvimento. Portanto a questão passa a ser qual deve ser o mínimo adequado para que a criança tenha oportunidades de desenvolvimento.

No que diz respeito ao sexo da criança não foi percebida diferença estatisticamente significante tanto no resultado global como na área de linguagem. $\mathrm{O}$ que também constatou Cunha (2000) e Halpern et al. (1996). Diferenças de desempenhos entre os sexos foram encontradas por Durmazlar (1998).

Na avaliação global do TTDD II todas as avaliações com resultado "normal” aumentaram percentualmente quando comparadas à primeira (Tabela 3), sendo a segunda e a terceira significativamente melhores.

Sem dúvida novamente se coloca a questão, até que ponto se deram influências relativas de cada uma das instituições: creche e família. Sabemos que este estudo tal como está desenhado, não permite que obtenha esta resposta. No entanto ele nos traz uma inferência importante: as creches não prejudicaram o desenvolvimento das crianças podendo até mesmo tê-lo incrementado. 
A análise estratificada por idade mostrou que crianças de $>1$ a $\leq 2$ de idade (Tabela 5) apresentam resultados significantemente melhores a medida que o período de permanência na creche aumenta.

O mesmo ocorreu no caso das crianças de $>3$ a $\leq 4$ anos de idade (Tabela 7), em que freqüentar às creches por períodos de 24 à 39 meses, redundou em resultados significantemente melhores.

O estudo de coorte de Peisner-Feinberg et al. (2001) realizado em várias cidades dos Estados Unidos e já mencionado, consistiu em um acompanhamento de 733 crianças de 4 a 8 anos. Mostrou que instituições de boa qualidade criam condições favoráveis para o desenvolvimento cognitivo, social e de linguagem. Estes efeitos positivos persistem até 4 anos depois, favorecendo o aproveitamento escolar.

Assim, as evidências apontam para o fato de que a creche, novamente, não prejudicou o desenvolvimento podendo, inclusivo, tê-lo incrementado.

No que diz respeito à linguagem as avaliações consideradas sucessivamente não mostraram diferença significante entre os cinco momentos (Tabela 11). No entanto os números absolutos e relativos mostram uma tendência preocupante. Após a primeira porcentagem de adequações, $78,8 \%$, o valor aumenta $(84,8 \%)$ na segunda, mas caiu nas $3^{\mathrm{a}}$ e $4^{\mathrm{a}}\left(73,3 \%\right.$ e $67,9 \%$ respectivamente). Somente na $5^{\mathrm{a}}$ há recuperação do índice, $84,6 \%$, que ultrapassa o da $1^{\text {a }}$ avaliação.

A priori não é possível delimitar a causa, mas é interessante lembra que outros estudos também mostraram o quanto a linguagem é vulnerável em seu percurso em direção há um desenvolvimento adequado. Caon e Ries (2003) em seu estudo já apresentado descobriram que a área de linguagem foi a mais acometida, seguida por pessoal-social, motor fino e motor grosso. 
Souza e Siqueira (2003) em trabalho igualmente já mencionado também perceberam a área de habilidade de linguagem como a mais acometida.

Rezende, Costa e Pontes (2005) obtiveram o mesmo.

Apesar de nas 3 pesquisas citadas ter sido usado o mesmo instrumento, o TTDD II, não podemos comparar as cifras, exceto com a de Rezende, Costa e Pontes (2005). Isto por que nas duas primeiras os autores não definiram com exatidão o que consideraram como resultados anômalos.

Assim as porcentagem de resultados tipo "risco" neste trabalho (Tabela 11) foram respectivamente nas 5 avaliações: $21,2 \% ; 15,2 \% ; 26,7 ; 32,1 \%$ e $15,4 \%$. Na pesquisa de Rezende, Costa e Pontes foi $25,8 \%$. Tais resultados mostram que mesmo em creches considerados de bom padrão de qualidade (como as deste trabalho) e que correspondem a situações familiares também melhores, é relativamente comum o acometimento. Outros trabalhos mostram estas evidências como o de Andrade (1997) que avaliou, em 1993, 2980 crianças de 1 a 11 anos de idade, atendidas em unidade básica de saúde da cidade de São Paulo, na região do Butantã. Nesta população a maior frequiência de dificuldades de comunicação aconteceu nas crianças de 3 a 6 anos, com ênfase na linguagem oral nas de 3 anos. De acordo com a autora uma possível explicação seria a "imaturidade neurofisiológica para aquisição e domínio da linguagem e também, os fatores sociais relacionados à estimulação necessária para que os padrões lingüísticos se desenvolvam. Segundo a coordenadora do programa de fonoaudiologia da mesma unidade básica de saúde: "nos casos de defasagem de linguagem, como manifestação primária, o fator ambiental é de grande importância. A criança sendo pouco exposta à situações de comunicação, terá menos oportunidade de usar linguagem oral como forma de expressão". 
Aliás, a dificuldade de as crianças expressarem suas potencialidades na área de habilidades de linguagem já vem sendo constatada também em escolas que atendem à população de bom nível sócio-econômico (Toledo, 2000).

Estas evidências apontam na direção de uma dificuldade generalizada, desencadeada, tanto por creches e escolas, como no âmbito da própria família.

Há 2 estudos que corroboram a tese de que a importância da família é crucial para a o desenvolvimento da linguagem, mas, a creche de bom padrão de atendimento também. São os de Bonamigo (2000) e Ramos et al. (2002).

Bonamigo (2000) comparou o desenvolvimento da linguagem oral de crianças de 4 anos e 1 mês até 5 anos e 4 meses que freqüentavam creches públicas da cidade de São Paulo. Todas as crianças tinham condições econômicas precárias. Foram estudadas 2 grupos: um com crianças com tempo de freqüência menor do 6 meses e outra com mais do que 4 anos. As educadoras das creches em questão tinham sido previamente treinadas para suas tarefas. As crianças que frequientavam as instituições há mais do que 4 anos tinham desenvolvimento de linguagem adequado para a idade, enquanto no outro grupo o índice de defasagem era de $83,33 \%$.

Ramos et al (2002) comparou o desenvolvimento de linguagem de 36 crianças de 12 a 24 meses que freqüentavam creches particulares e 36 crianças da mesma faixa etária em creches públicas. Verificaram que as crianças de creches públicas têm ritmo de desenvolvimento significantemente mais lento que as crianças de creches particulares. 
Ao se levar em conta os resultados seguindo as idades das crianças vê-se que os resultados são significantes na idade de $>3 \mathrm{a} \leq 4$ anos. Nesta, uma freqüência à creche entre 24 e 39 meses está associada à resultados significantemente melhores.

Mesmo havendo melhora neste período, é importante notar que das 30 crianças nesta faixa etária 17 (56,66\%) apresentaram risco.

Finalmente não pode se deixar de considerar a importância de se proceder à validação do TTDD II para nosso país. Esta preocupação é especialmente evidente nas áreas de linguagem e pessoal-social e delas compartilham também Caon, Ries (2003) aos quais damos voz: "Dessa forma, a grande incidência de atraso na área de linguagem encontrada neste estudo, resultado atípico quando comparados a outros estudos brasileiros (ponto do qual discordamos, tal como comentado anteriormente) pode estar evidenciado a necessidade de adequação do Teste de Denver II diante dos pormenores socioculturais da população estudada.

Ao analisarmos os resultados faz-se imperativo abordar as condições das creches.

Sem dúvida, analisar condições, sendo estas tão complexas, exige um considerável esforço do pesquisador no sentido apreendê-las especialmente. Assim, valemo-nos da caracterização elaborada por Burchinal et al. (1996, 2000), quais sejam, a proporção adulto/criança (nos grupos que participaram da pesquisa) e as comparamos ao preconizado pela Secretaria do Menor (Secretaria do Menor, 1992) e o Conselho Estadual de Educação de São Paulo (São Paulo citado por Correa, 2003). Esta comparação está ilustrada na quadro 6. 


\begin{tabular}{|c|c|c|c|c|c|}
\hline \multicolumn{5}{|c|}{ Quadro 6- Proporção educador/criança em creches, 2001-2004. } \\
\hline $\begin{array}{c}\text { Faixa etária } \\
\text { em anos }\end{array}$ & $\begin{array}{c}\text { Proporção } \\
\text { recomendada } \\
\text { Secretaria menor* }\end{array}$ & $\begin{array}{c}\text { Proporção } \\
\text { recomendada } \\
\text { Conselho Estadual** }\end{array}$ & Creche A & Creche B & Creche C \\
\hline $0+1$ & $1 / 5$ & $1 / 6$ & $1 / 5$ & $1 / 5$ & $1 / 5$ \\
\hline 1 ㄴ & $1 / 5$ & $1 / 8$ & $1 / 5$ & $1 / 5$ & $1 / 5$ \\
\hline 2 - 3 & $1 / 10$ & $1 / 10$ & $1 / 7$ & $1 / 6$ & $1 / 8$ \\
\hline 3 - 4 & $1 / 10$ & $1 / 15$ & $1 / 18$ & $1 / 17$ & $1 / 16$ \\
\hline 4 F 5 & $1 / 10$ & $1 / 20$ & $1 / 20$ & $1 / 20$ & $1 / 18$ \\
\hline 5 H 6 & $1 / 13,5$ & $1 / 25$ & $1 / 21$ & $1 / 20$ & $1 / 23$ \\
\hline
\end{tabular}

*São Paulo (1992)

** São Paulo citado por Correa (2003)

Em todas as faixas etárias, exceto a de 3 a 4 anos, as proporções educadora/criança estão adequadas nas 3 instituições, porém após os 3 anos, justamente a idade alterada na área de linguagem, esta relação aumenta, chegando a 16-18 crianças por educadora.

Vale ressaltar que as creches contam com educadoras avulsas que auxiliam nos momentos de excesso de trabalho, como por exemplo, período de adaptação e horário de refeições, e que eventualmente substituem educadoras ausentes. No entanto, seria difícil considerá-las nos cômputos, uma vez que são compartilhadas por várias salas. Além disto, é uma característica destas creches o empenho em desenvolver a autonomia da criança. Percebe-se, acompanhando a rotina da instituição, que as crianças desta fase parecem depender menos das educadoras, que, no entanto, estão sempre perto e focalizadas nas suas necessidades. Assim, é possível concluir que a autonomia das crianças nesta idade as torna mais suscetíveis em termos de desenvolvimento da linguagem, e que a interferência ambiental, ou seja, a 
menor proporção educador por crianças, pode contribuir para incrementar esta vulnerabilidade. No entanto, temos sempre em mente que o estudo tem limitações devido ao fato de não ter desenhado para rastrear as influências decorrentes da família, e as específicas da creche.

Um estudo americano avaliou o desenvolvimento cognitivo e de linguagem de 79 crianças de 12 meses que freqüentavam creches por no mínimo 10 meses. A qualidade da creche foi avaliada considerando estrutura (tamanho da classe e proporção adulto/criança) e processo (comportamento do professor como sensibilidade para atender aos interesses e necessidades infantis, além de providenciar atividades apropriadas para o seu desenvolvimento). As crianças que estavam em classes como melhor proporção criança/adulto eram mais avançadas no desenvolvimento da linguagem. (Burchinal et al.,1996). Este resultado foi confirmado quando as mesmas crianças tinham 3 anos de idade (Burchinal et al., 2000).

Shibayama (2001) fez um estudo na mesma creche B e concluiu que as educadoras/cuidadoras percebem o quanto o ambiente e o ato de conversar/escutar com as crianças é importante para o desenvolvimento delas. O indicador "conversar" é um dos mais significativos em termos de qualidade de uma instituição pelo que implica que o educador tenha um conceito adequado de criança, bem como de seu próprio papel enquanto professor e cuidador. Além disto, conversar tendo a criança como foco da atenção, tal como foi constatado no trabalho de Shibayama (2001) sem dúvida é um marco em termo de qualidade, uma vez que o conversar rotineiro em nosso meio é basicamente utilitarista, isto é, presta-se apenas a transmissão de informações e ordens 
È fundamental levarmos em conta estes indicadores, pois são tentativas de qualificação do ambiente no qual a criança está inserida. Assim, a questão da qualidade no cuidado à criança que freqüenta creches, e mesmo no âmbito da família, é um dos pontos chaves que precisa ser levado em conta em nossa área. 


\section{CONCLUSÕES E RECOMENDAÇÕES}

- As evidências sugerem que freqüentar estas creches pode ter sido benéfico para as crianças em termos globais.

- O mesmo não se pode dizer quanto a linguagem uma vez que os resultados se mostram inalterados ao longo do tempo.

- Não é possível aquilatar a influência relativa de cada uma das esferas de cuidado: família e creche, uma vez que esta pesquisa não foi desenhada com esta finalidade.

- É possível sugerir uma revisão de normas e condutas das instituições envolvidas em relação ao número de educadoras na faixa etária de 3 anos.

- Quaisquer outras alterações de normas e rotinas nas instituições não são recomendadas no momento, especialmente devido ao fato de que outros estudos apontam na direção da boa qualidade das instituições envolvidas no estudo.

- É altamente recomendável a validação do TTDD II para a língua portuguesa e, especificamente para o contexto brasileiro, a fim de se descartar as influências dele oriundas. 


\section{REFERÊNCIAS}

Andrade CRF. Prevalência das desordens idiopáticas da fala e da linguagem em crianças de um a onze anos de idade. Rev Saúde Pública. 1997;31(5):495-501.

Bedregal P, Margozzini P, Molina H. Revisión sistemática sobre eficacia y costo de intervenciones para el desarrollo biosicosocial de la niñez. Santiago de Chile: OPAS/OMS, Oficina Regional; 2002.

Bee H. A criança em desenvolvimento. Trad. de Maria Adriana Veríssimo Veronese. $9^{\mathrm{a}}$ ed. Porto Alegre: Artmed; 2003.

Berquó ES, Souza JMP, Gotlieb SLD. Bioestatística. 2ª ed. São Paulo: EPU; 2002. Amostragem; p. 133-45.

Beteli VC, Lima FG, Rezende MA, Santos JLF. Habilidades motoras de crianças de 0 a 3anos que frequientam creches: aplicação do Teste de Triagem de Desenvolvimento de Denver II. Rev Soci Bras Enferm Pediatras. 2003;3(2):75-84.

Bonamigo AW. O desenvolvimento da linguagem oral de crianças no contexto de uma creche [tese]. São Paulo: Faculdade de Saúde Pública da USP; 2000.

Bowlby J. Apego. São Paulo: Martins Fontes; 1984.

Brêtas JRS. Avaliação psicomotora de crianças de 5 a 7 anos de idade, que freqüentam a creche "Maria Aparecida Carlini", Jardim Sabiá , Município de São Paulo [dissertação]. São Paulo: Escola Paulista de Medicina da UNIFESP; 1991.

Brêtas JRS, Cassula DA, Reis LL. Características do desenvolvimento de lactentes e pré-escolares, utilizando o teste de triagem de desenvolvimento de denver. Temas Desenvolv. 2001; 9(54):5-13.

Broberg AG, Wessels H, Lamb ME, Hwang CP. Effects of day care on the development of cognitive abilities in 8 year-olds: a longitudinal study. Dev Psychol. 1997;33(1):62-9.

Bronfenbrenner U. A ecologia do desenvolvimento humano: experimentos naturais e planejados. Trad. de Maria Adriana Veríssimo Veronese. Porto Alegre: Artes Médicas; 1996.

Burchinal MR, Roberts JE, Nabors LA, Bryant DM. Quality of center child care and infant cognitive and language development. Child Dev. 1996; 67: 606-20.

Burchinal MR, Roberts JE, Riggins R, Zeisel SA, Neebe E, Bryant DM. Relating quality of center-based child care to early cognitive and language development longitudinally. Child Dev. 2000;71(2):339-57. 
Campbell FA, Ramey CT. Effects of early intervention on intellectual and academic achievement: a follow-up study of children from low- income families. Chil Dev. 1994; 65: 684-98.

Caon G, Ries LGK. Suspeita de atraso no desenvolvimento neuropsicomotor em idade precoce: uma abordagem em creches públicas. Temas Desenvolv. 2003;12(70):11-7.

Cardoso RM. Conhecimento de mães e auxiliares de desenvolvimento infantil referente ao desenvolvimento de linguagem de crianças de 0 a 24 meses de idade. [dissertação]. São Paulo: Escola Paulista de Medicina da UNIFESP; 2001.

Cunha HL. Desenvolvimento de crianças atendidas no hospital de pediatria da Universidade Federal de Rio Grande do Norte no primeiro ano de vida: aplicação do Teste de Denver II em ambulatório. [dissertação]. São Paulo: Escola Paulista de Medicina da UNIFESP; 2000.

Cloninger SC. Teorias da personalidade. Trad. de Claudia Berliner. São Paulo: Martins Fontes; 1999.

Correa BC. Considerações sobre qualidade na educação infantil. Cad Pesq. 2003; 119:85-112.

Durmazlar N. Turkish children's performance on Denver II: effect of sex mother's education. Dev Med Child Neurol 1888; 40(6):411-6.

Ferreira AMA . Avaliação nutricional e do desenvolvimento de crianças de 0 a 3 anos de idade que freqüentam creches conveniadas com a Secretaria Municipal do Bem-Estar Social de São Paulo na regional da Lapa [dissertação]. São Paulo: Escola Paulista de Medicina da UNIFESP; 1989.

Figueiras ACM, Souza ICN, Pedromônico MRM. Manual para vigilância do desenvolvimento infantil no contexto da AIDPI. Belém: Secretaria Municipal da Saúde; 2003.

Fisberg M, Pedromônico MRM, Braga JAP, Ferreira C, Pini, SCC, Campos SO, et al. Comparação do desempenho de pré-escolares, mediante teste de desenvolvimento de Denver, antes e após intervenção nutricional. Rev Ass Med Brasil. 1997;43(2): 99-104.

Frankenburg WK, Dodds J, Archer P, Bresnick B, Maschka P, Edelman N, et al. Denver II Training Manual. Denver: Denver Developmental Materials; 1992a.

Frankenburg WK, Archer P, Shapiro H, Bresnick B. The Denver II: a major revision and restandardization of the Denver Developmental Screening Test. Pediatrics 1992b; 89(1):91-7. 
Frankenburg WK. Does Denver II: produce meaningful results? Pediatrics 1992;90 (3):477-9.

Frankenburg WK. Preventing developmental delays: is developmental screening sufficient? Pediatrics. 1994;93(4):586-593.

Frankenburg WK, Dodds J, Archer P, Bresnick B, Maschka P, Edelman N, et al. Denver II. Trad. de Márcia Regina Marcondes Pedromônico, Eliane Lopes Bragatto e Renata Strobilius. São Paulo; 1999. [formulário].

Galvão I. Henri Wallon: uma concepção dialética do desenvolvimento infantil. $8^{\mathrm{a}} \mathrm{ed}$. Petrópolis: Vozes; 2000.

Halpern R, Barros FC, Horta BL, Victora CG. Desenvolvimento neuropsicomotor aos 12 meses de idade em uma coorte de base populacional no Sul do Brasil: diferenciais conforme peso ao nascer e renda familiar. Cad Saúde Pública. 1996;12 Supl 1:73-8.

Halpern R, Giugliani ERJ, Victora CG, Barros FC, Horta BL. Fatores de risco para suspeita de atraso no desenvolvimento neuropsicomotor aos 12 meses de vida.

J Pediatr. 2000;76(6):421-8.

Hugues MS. Avaliação, através do exame físico e teste de Gesell, de aspectos de saúde de crianças de 2 a 44 meses de idade, que freqüentam a creche Maria Aparecida Carlini, Jardim Sabiá, Bairro do município de São Paulo. [dissertação]. São Paulo: Escola Paulista de Medicina da UNIFESP; 1986.

Issler RMS, Giugliani ERJ. Identificação de grupos vulneráveis à desnutrição infantil pela medição do nível de pobreza. J Pediatr. 1997;73:101-5.

Kakehashi S. Avaliação de alguns aspectos do desenvolvimento motor grosso e fino adaptativo, pessoal social e de linguagem das crianças de 2 a 6 anos de idade da creche "Maria Aparecida Carlini”, Jardim Sabiá, São Paulo [dissertação]. São Paulo: Escola Paulista de Medicina da UNIFESP; 1987.

Ministério da Educação e do Desporto. Secretaria de Educação Fundamental. Referencial Curricular Nacional para a Educação Infantil. Brasília; 1998. v1.

Ministério da Saúde. Secretaria de Políticas de Saúde. Saúde da criança: acompanhamento do crescimento e desenvolvimento infantil. Brasília; 2002. (Série Cadernos de Atenção Básica, n. 11; Série A. Normas e Manuais Técnicos, n. 173).

National Institute of Child Health and Human Development (NICHD) Early Child Care Research Network. The relation of child care to cognitive and language development. Child Dev. 2000;71(4):960-80. 
O'Hara MT, Church CC, Blatt SD. Home-based developmental screening of children in foster care. Pediatr Nurs.1998;24(2):113-7.

Peisner-Feinberg ES, Burchinal MR, Clifford RM, Culkin ML, Howes C, Kagan SL, et al. The relation of preschool child-care quality to children's cognitive and social developmental trajectories through second grade. Child Dev.2001;72(5):1534-53.

Polit DF, Beck CT, Hungler BP. Fundamentos de pesquisa em enfermagem. Trad. de Ana Thorell. 5a ed. Porto Alegre: Artmed; 2004.

Ramos CS, Pedromônico MRM, Shinzato AR, DeLucas S. Comparação do desenvolvimento do comportamento de crianças de creches públicas e particulares no segundo ano de vida. Pró-fono 2002;14(3):401-8.

Rezende MA, Silva CV. Cuidado em creches e pré-escolas segundo os pressupostos de Mayeroff. Acta Paul Enferm.2002;15(4):73-8.

Rezende MA, Lima FG, Beteli VC, Santos JLF. Habilidades de linguagem e pessoal social de crianças de 0 a 3 anos de idade cuidadas em creches. Rev Bras Cresc Desenv Hum .2003;13(1):40-53.

Rezende MA. Uma proposta de cuidado à criança em creches e pré-escolas: a busca de superação dos determinantes históricos e sociais brasileiros. Acta Paul Enferm. 2004;17(1):102-7.

Rezende MA, Veríssimo MLÓR. Adaptação da criança em creches e pré-escolas: uma questão de saúde. In: Santos LES. Creche e pré-escola: uma abordagem de saúde. São Paulo: Artes Médicas; 2004. p.63-70.

Rezende MA, Beteli VC, Santos JLF. Avaliação de habilidades de linguagem e pessoal-sociais pelo Teste de Denver II em instituições de educação infantil. Acta Paul Enferm 2005a; 18 (1): 56-63.

Rezende MA, Beteli VC, Santos JLF. Follow-up of the child's motor abilities in daycare center and pre-schools. Rev Lat Am Enferm 2005b; 13 (5): 619-25.

Rezende MA, Costa OS, Pontes PB. Triagem de desenvolvimento neuropsicomotor em instituições de educação infantil segundo o Teste de Denver II. Escola Anna Nery Rev Enferm. 2005c; 9(3):348-55.

Secretaria do Menor. Creche/Pré-escola. São Paulo; 1992.

Sekkel MC. Reflexões sobre a experiência com a educação infantil: possibilidade de uma educação contra a violência na primeira infância [dissertação]. São Paulo: Instituto de Psicologia da USP; 1998.

Setti LB. A importância da aquisição da linguagem na pré-escola. Temas Desenvolv. 1994; 3(18):19-24. 
Shibayama RSV. O conversar com crianças de creches segundo suas educadoras/cuidadoras. [dissertação]. São Paulo: Escola de Enfermagem da USP; 2001 .

Shore R. Repensando o cérebro: novas visões sobre o desenvolvimento inicial do cérebro. Trad. de Iara Regina Brasil. Porto Alegre: Mercado Aberto; 2000.

Souza ABG, Siqueira CN. Avaliação do desenvolvimento de um grupo de crianças assistidas em creche, usando o teste de triagem de Denver II. Enferm Brasil. 2003; 2 (2):96-103.

Taille YA, Oliveira MK, Dantas H. Piaget, Vygotsky, Wallon: teorias psicogenéticas em discussão. São Paulo: Summus; 1992.

Toledo MNC. Mãe! E agora, o que é que eu falo? Avisalá. 2000;1(2):27-30.

Veríssimo MLÓR, Sigaud CHS, organizadoras. Enfermagem pediátrica: o cuidado de enfermagem à criança e ao adolescente. São Paulo: EPU; 1996. p.11-4.

Veríssimo MLÓR. Ações de enfermagem para a promoção da saúde infantil. In: Ministério da Saúde. Instituto para o Desenvolvimento da Saúde. Manual de enfermagem. Programa Saúde da Família. São Paulo; 2001a.

Veríssimo MLÓR. O olhar de trabalhadoras de creches sobre o cuidado da criança. [tese]. São Paulo: Escola de Enfermagem da USP; 2001b.

Veríssimo MLÓR. O desenvolvimento infantil e o cuidado da criança pela família. In: Secretaria Municipal de Saúde de São Paulo. Programa Saúde da Família. Nossas crianças: janelas de oportunidades. São Paulo: Unicef/Associação Comunitária Monte Azul; 2002. p. 31-6.

Veríssimo MLÓR. Estudo sobre infecções respiratórias agudas em creches. [Relatório Pesquisa]. São Paulo (SP): Escola de Enfermagem USP; 2004.

Vygotsky LS. Formação social da mente: o desenvolvimento dos processos psicológicos superiores. $6^{\mathrm{a}}$ ed. São Paulo: Martins Fontes; 2000.

Waldow VR. Cuidado humano: o resgate necessário. Porto Alegre: Sagra Luzzato; 1998.

Wertzner HF. Alterações da linguagem como manifestações primárias. In: Issler H, Leone CL, Marcondes E, organizadores. Pediatria na atenção primária. São Paulo: Sarvier; 2002. p.248-55. 
Wong DL. Whaley \& Wong enfermagem pediátrica: elementos essenciais à intervenção efetiva. $5^{\text {a }}$ ed. Rio de Janeiro: Guanabara Koogan; 1999. 


\section{ANEXO 1}

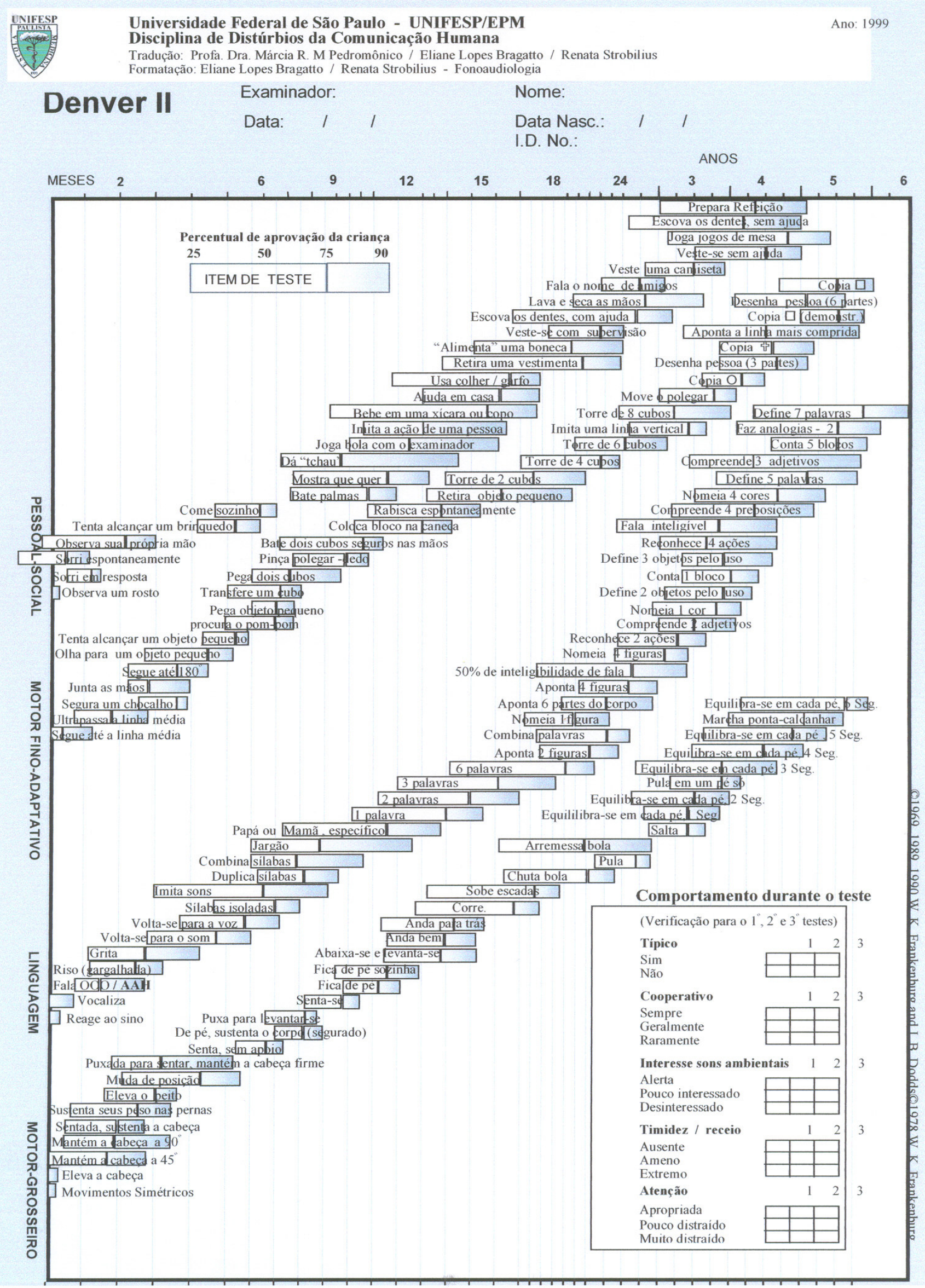


ANEXO 2
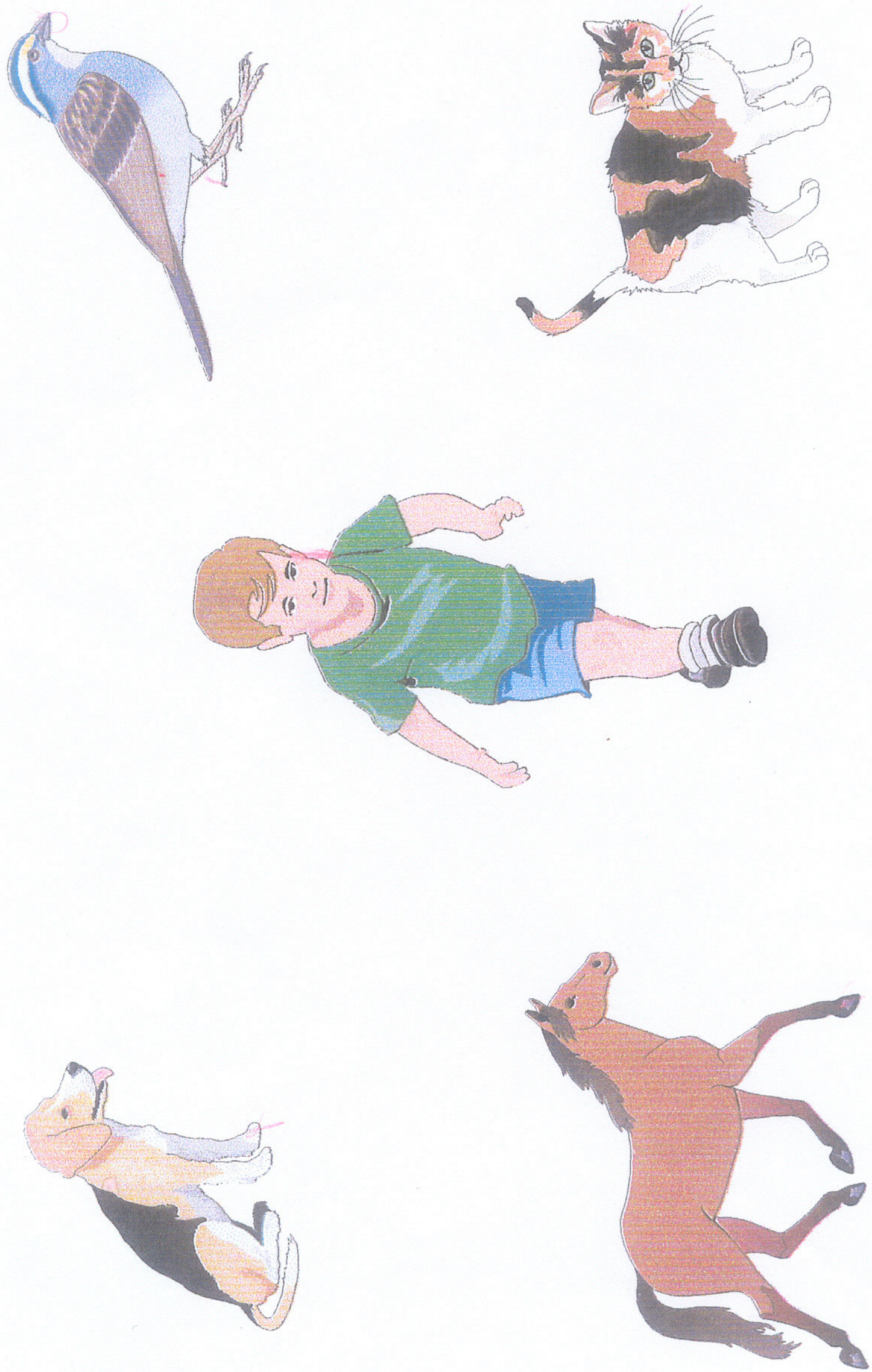


$$
\begin{aligned}
& \| \square \\
& +0
\end{aligned}
$$




\begin{abstract}
ANEXO 4
AVALIAÇÃO DAS CONDIÇÕES GERAIS DA CRIANÇA ANTES DA APLICAÇÃO DO DENVER II.
\end{abstract}

Nome da criança:

Data de nascimento:

\begin{tabular}{|l|}
\hline ano mês dia \\
data do teste \\
data de nascimento \\
\hline idade da criança \\
\hline
\end{tabular}

Idade gestacional: semanas e dias

$\square$ ajuste $\square$ não ajuste

Peso ao nascer: g

Está vivendo alguma situação potencialmente estressante:

$\square$ separação dos pais

$\square$ nascimento de irmão

$\square$ morte na família

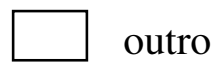

No dia da avaliação checar se:
$\square$ a criança está com sono?
$\square$ fatigada?
$\square$ adoentada?
$\square$ com febre?
$\square$ com medo? 


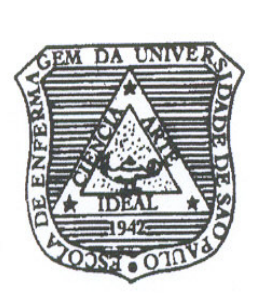

ANEXO 5

UNIVERSIDADE DE SÃO PAULO

ESCOLA DE ENFERMAGEM

Av. Dr. Enéas de Carvalho Aguiar, 419 - CEP 05403-000

IP Fone.: 3066-7548 - Fax.: 280-8213

C.P. 41633 - CEP 05422-970 - e-mail.: ee@edu.usp.br

São Paulo, 13 de março de 2001.

$\mathrm{Ilm}^{\mathrm{a}} \mathrm{Sr}^{\mathrm{a}}$

PROF $^{\mathrm{a}}$ DR $^{\mathrm{a}}$ MAGDA ANDRADE REZENDE

Ref.: Processo $n^{0} 136 / 2001$

Em atenção à solicitação referente à análise do projeto "HABILIDADES

DE LINGUAGEM EM CRIANÇAS DE 0 A 3 ANOS DE IDADE CUIDADAS EM

CRECHES: UMA QUESTÃO DE SAÚDE", informamos que o mesmo foi considerado aprovado pelo Comitê de Ética em Pesquisa da Escola de Enfermagem da Universidade de São Paulo (CEP/EEUSP).

Analisado sob o aspecto ético-legal, atende às exigências da Resolução $\mathrm{n}^{\circ}$ 196/96 do Conselho Nacional de Saúde.

Esclarecemos que após o término da pesquisa, os resultados obtidos deverão ser encaminhados ao CEP/EEUSP, para serem anexados ao processo.

Atenciosamente,

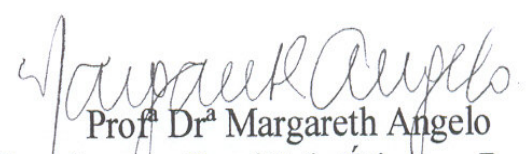

Coordenąora do Comitê de Ética em Pesquisa

da Escola de Enfermagem da Universidade de São Paulo 


\author{
ANEXO 6 \\ UNIVERSIDADE DE SÃO PAULO \\ ESCOLA DE ENFERMAGEM \\ Av. Dr. Enéas de Carvalho Aguiar, 419 - CEP 05403-000 \\ ? Fone.: 3066-7548 - Fax.: 280-8213 \\ C.P. 41633 - CEP 05422-970 - e-mail.: ee@edu.usp.br
}

São Paulo, 02 de julho de 2002.

$\operatorname{Ilm}^{\mathrm{a}} \mathrm{Sr}^{\mathrm{a}}$

PROF $^{a}$ DR $^{a}$ MAGDA ANDRADE REZENDE

Ref.: Processo n ${ }^{0} 248 / 2002$

Em atenção à solicitação referente à análise do projeto

"O DESENVOLVIMENTO INFANTIL EM CRECHES/PRÉ-ESCOLAS: UM ESTUD0 DE COORTE", informamos que o mesmo foi considerado aprovado pelo Comitê de Ética em Pesquisa da Escola de Enfermagem da Universidade de São Paulo (CEP/EEUSP).

Analisado sob 0 aspecto ético-legal, atende às exigências da Resolução nº 196/96 do Conselho Nacional de Saúde.

Esclarecemos que após o término da pesquisa, os resultados obtidos deverão ser encaminhados ao CEP/EEUSP, para serem anexados ao processo.

Atenciosamente,

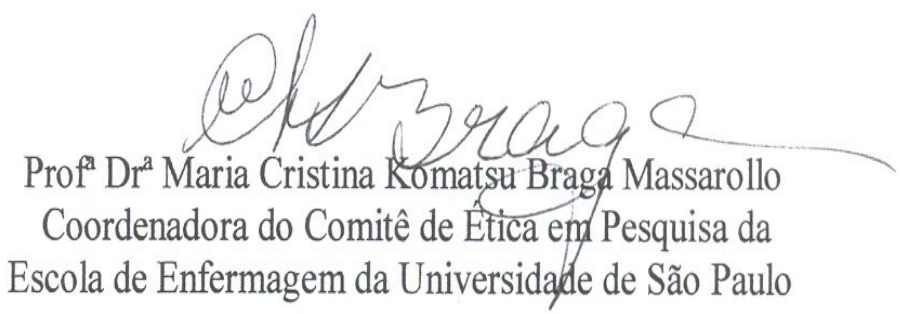




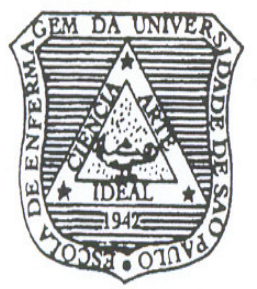 \\ UNIVERSIDADE DE SÃO PAULO \\ ESCOLA DE ENFERMAGEM \\ Av. Dr. Enéas de Carvalho Aguiar, 419 - CEP 05403-000 \\ Pone.: 3066-7548 - Fax.: 280-8213 \\ C.P. 41633 - CEP 05422-970 - e-mail.: edipesq@usp.br
}

São Paulo, 04 de outubro de 2004.

Ilm. ${ }^{a} \mathrm{Sr}^{\mathrm{a}}$

Vívian César Beteli

$\underline{\text { Ref.: Processo n 397/2004/CEP-EEUSP }}$

Prezada Senhora:

Em atenção à solicitação referente à análise do projeto "AVALIAÇÃO LONGITUDINAL DO DESENVOLVIMENTO INFANTIL EM CRECHES E PRÉESCOLAS SEGUNDO O TESTA DE TRIAGEM DE DESENVOLVIMENTO DE DENVER II", informamos que o mesmo foi considerado aprovado pelo Comitê de Ética em Pesquisa da Escola de Enfermagem da Universidade de São Paulo (CEP/EEUSP).

Analisado sob o aspecto ético-legal, atende às exigências da Resolução nº 196/96 do Conselho Nacional de Saúde.

Esclarecemos que após o término da pesquisa, os resultados obtidos deverão ser encaminhados ao CEP/EEUSP, para serem anexados ao processo.

Atenciosamente,

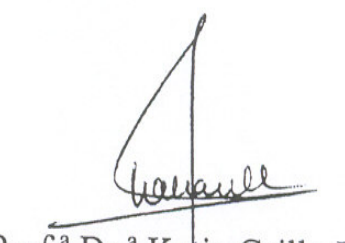

Prof. ${ }^{a}$ Dr. ${ }^{a}$ Katia Grillo Padilha

Decana do Comitê de Ética em Pesquisa da

Escola de Enfermagem da Universidade de São Paulo 


\section{ANEXO 8 \\ O DESENVOLVIMENTO INFANTIL EM CRECHES E PRÉ-ESCOLAS: UM ESTUDO DE COORTE}

\section{Termo de consentimento livre e esclarecido}

Prezado (a) senhor (a)

Meu nome é Vivian César Beteli e estou fazendo juntamente com a professora Dr ${ }^{\mathrm{a}}$ Magda Andrade Rezende, um trabalho a respeito do desenvolvimento da criança que freqüienta creche.

Para o trabalho, é necessário verificar se a criança realiza certas atividades adequadas para a sua idade. Não é teste de inteligência. Não se espera que a criança faça todos os itens. O objetivo do trabalho é saber como as crianças desta creche estão se desenvolvendo.

Caso o Sr/Sra concorde, seu filho será avaliado. Os testes não serão aplicados se a criança estiver cansada, doente ou com sono. Como se trata de uma pesquisa, precisamos fazer um relatório final e escrever trabalhos a respeito. Não identificaremos seu (sua) filho (a) nestes trabalhos. Comprometemo-nos a avisá-lo (a) e orienta-lo (a) caso seu (sua) filho (a) apresente algum resultado que comprometa seu desenvolvimento.

$\mathrm{O} \mathrm{Sr} / \mathrm{Sra}$ tem total liberdade para aceitar ou não esta pesquisa. Caso o $\mathrm{Sr} / \mathrm{Sra}$ não aceite, isto não vai causar nenhum prejuízo a se/sua filho (a) aqui na creche. $\mathrm{O}$ Sr/Sra concorda em participar?

Declaro que, após convenientemente esclarecido (a) pela pesquisadora e ter entendido o que me foi explicado, autorizo que meu filho (a) participe da presente pesquisa.

Assinatura do pai, mãe ou responsável pela criança.

Assinatura de uma das pesquisadoras.

As pesquisadoras poderão ser contatadas nos seguintes telefones e endereços:

Magda Andrade Rezende

Av. Dr Enéas de Carvalho Aguiar, 419

Telefone: (11) 3066-7602 ou 3066-7601

Vivian César Beteli

Rua Petronilha Antunes, 287, Jundiaí

Telefone: (11) 4586-7199 


\section{ANEXO 9}

Tabela 1 - Instrumento de medição do nível de pobreza *

1. Número de pessoas que comem e dormem na casa

1.4 pessoas 4 pontos

5.8 pessoas ............................................................ 3 pontos

9.12 pessoas .......................................................... 2 pontos

13-15 pessoas ......................................................... 1 ponto

mais de 15 pessoas ................................................. 0 ponto

2. Abandono do pai

Sem abandono 4 pontos

Abandono parcial ..................................................... 2 pontos

Abandono total ......................................................... 0 ponto

3. Escolaridade dos pais (a mais alta era considerada quando houvesse diferença)

Até $8^{\mathrm{a}}$ série ou mais................................................... 4 pontos

$5^{\mathrm{a}}$ a $7^{\mathrm{a}}$ série........................................................... 3 pontos

Até 4 série............................................................ 2 pontos

$1^{\mathrm{l}}$ a $3^{\mathrm{a}}$ série........................................................... 1 ponto

Analfabeto, nunca estudou ....................................... O ponto

4. Atividade dos pais (a mais alta era considerada quando houvesse diferença)

Dono de armazém, pequeno comércio ....................4 pontos

Trabalho regular ..................................................... 3 pontos

Trabalho por tarefa, biscateiro ................................. 2 pontos

Encostado, seguro-desemprego, aposentado ........ 1 ponto

5. Relação com o domicilio

Casa própria, em pagamento ...................................4 pontos

Casa alugada ........................................................... 3 pontos

Casa emprestada, em usufruto ................................ 2 pontos

Casa invadida .......................................................... 1 ponto

Morando de favor ........................................................ O ponto

6. Tipo de casa

Casa sólida, alvenaria ........................................... 4 pontos

Casa de madeira ou mista ..................................... 3 pontos

Casa simples, mais de 2 peças ............................. 2 pontos

Casa simples, 1 a 2 peças ....................................... 1 ponto
7. Número de pessoas que dormem na casa e lugares para dormir (cama de casal equivale a 2 lugares)

$\left(n^{0}\right.$ de pessoas) $-\left(n^{0}\right.$ de camas $)<2 \ldots . . . \ldots \ldots \ldots . . . . . . .44$ pontos

$\left(n^{0}\right.$ de pessoas $) \cdot\left(n^{0}\right.$ de camas $)>2 \ldots . . . . . . . . . . . . . . .11$ ponto

8. Abastecimento de água

água encanada, dentro de casa .............................. 4 pontos

água encanada, no terreno ..................................... 2 pontos

água carregada de vizinho, bica pública ................ 1 ponto

9. Deposiçăo de excreta

Descarga, ligada a fossa ou rede de esgoto ........... 4 pontos

Poço negro ou latrina .............................................. 2 pontos

Não tem (campo aberto) ............................................ O ponto

10. Coleta de lixo

Coleta domiciliar ...................................................... 4 pontos

Lixeira pública .......................................................... 3 pontos

Lixo queimado ou enterrado ..................................... 2 pontos

Lixo jogado em campo aberto .................................... 1 ponto

11. Energia elétrica

Com registro próprio ................................................ 4 pontos

Com registro comum a várias casas ...................... 3 pontos

Não tem energia elétrica ........................................ O ponto

12. Cozinha independente

Sim ................ 4 pontos Não................... 1 ponto

13. Equipamentos do domiclio

Geladeira ....... 8 pontos Televisão.......... 4 pontos

Fogão ............ 2 pontos Rádio ................ 1 ponto

Soma 15 pontos ............... 4 pontos

10-14 pontos .......... 3 pontos

4-9 pontos ............. 2 pontos

1-3 pontos .............. 1 ponto

0 ponto ................... 0 ponto

-Adaplado de Alvarez et al.? 


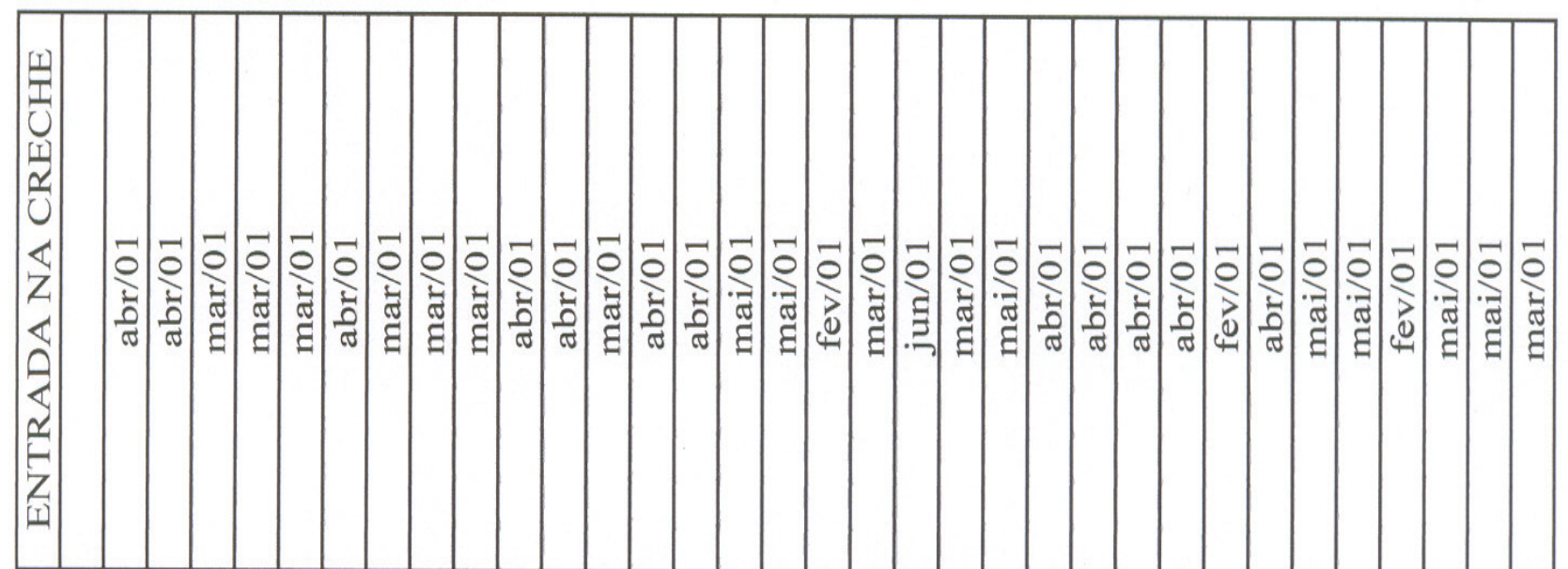

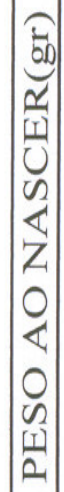

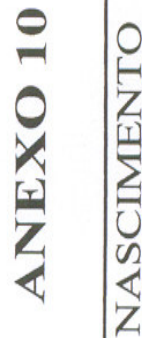

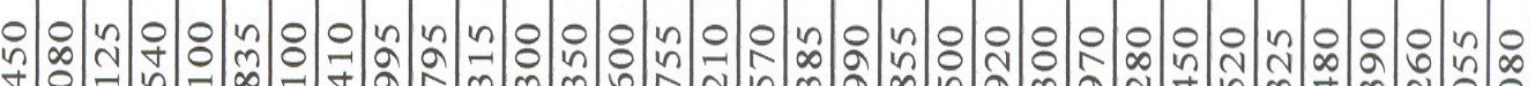

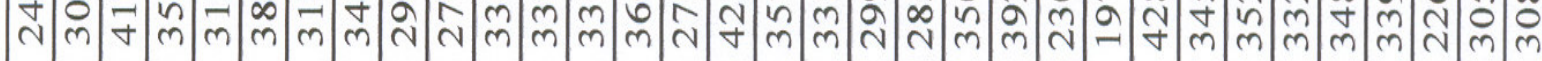

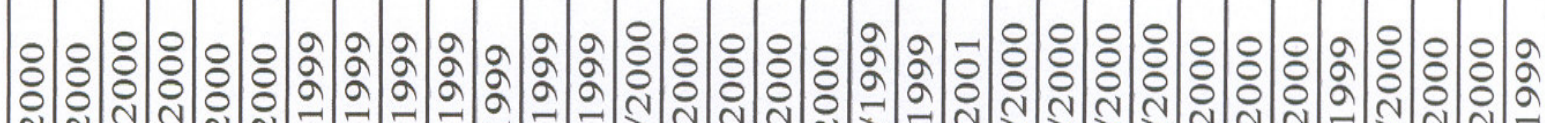

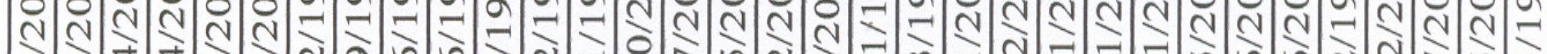

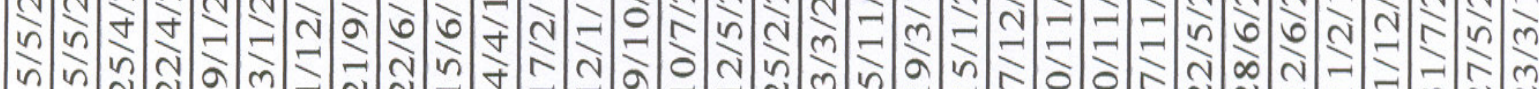

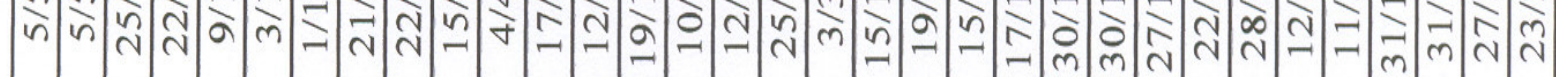
Z)

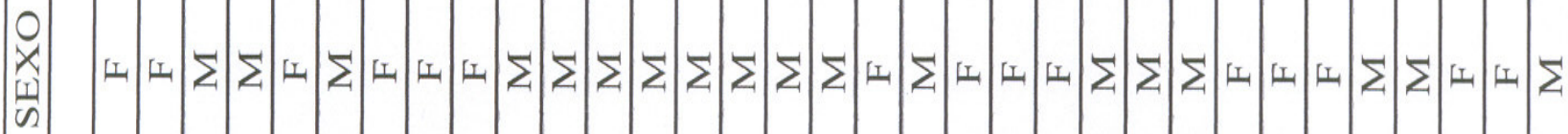

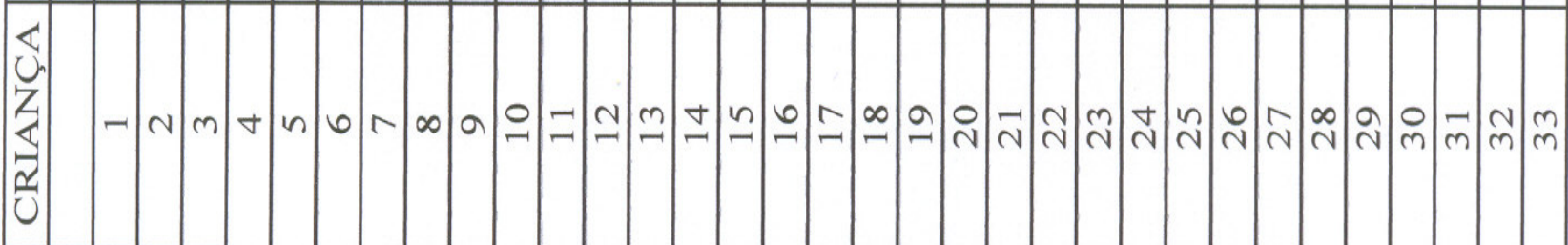

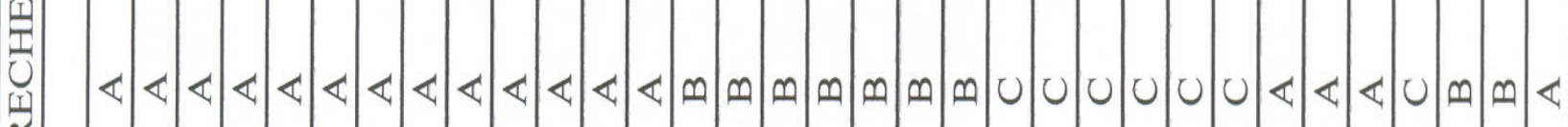




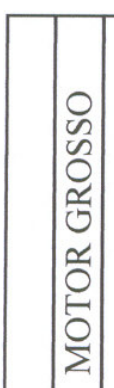

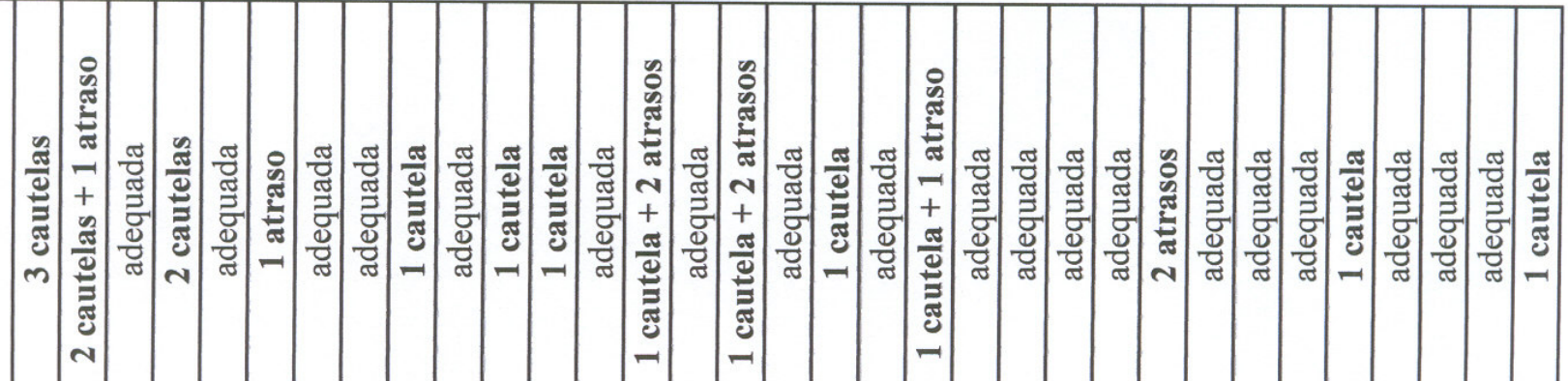

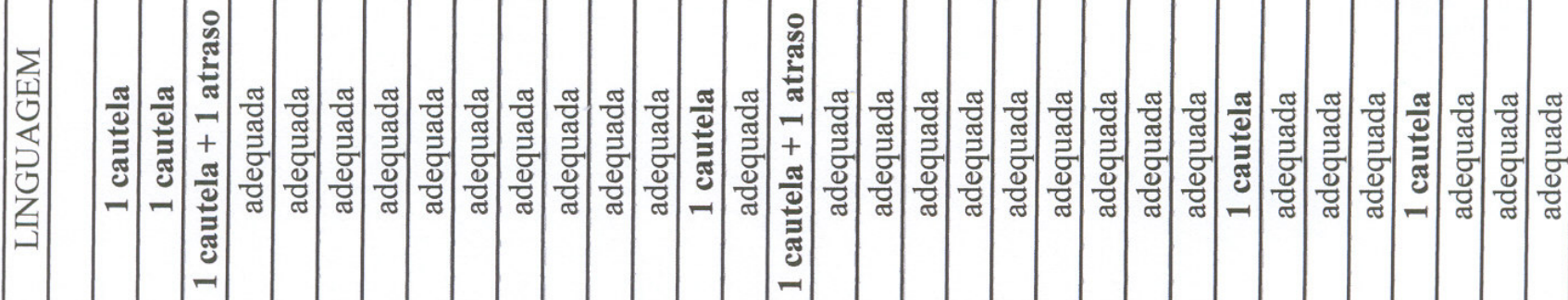

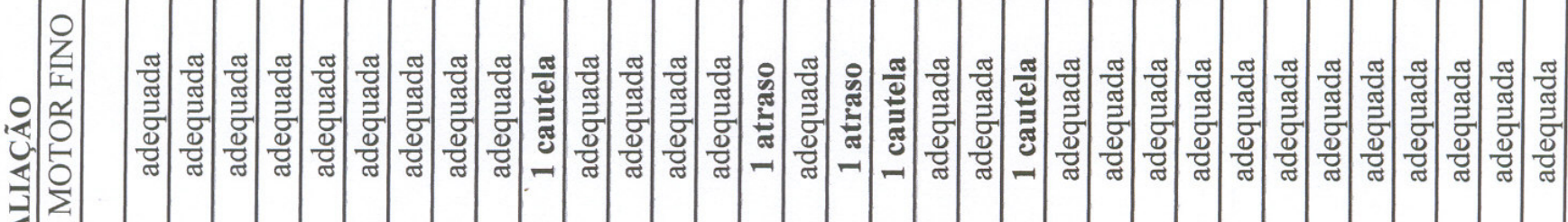
4

ป

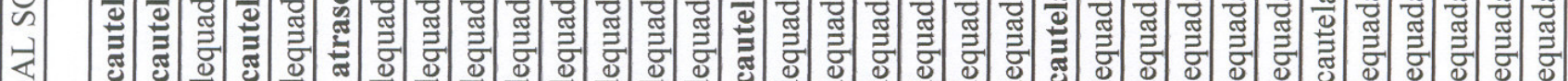

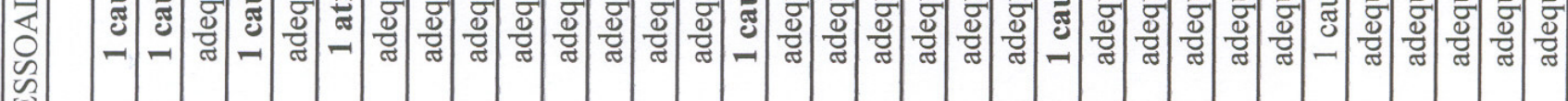

뙬

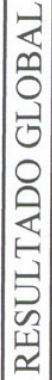

叫

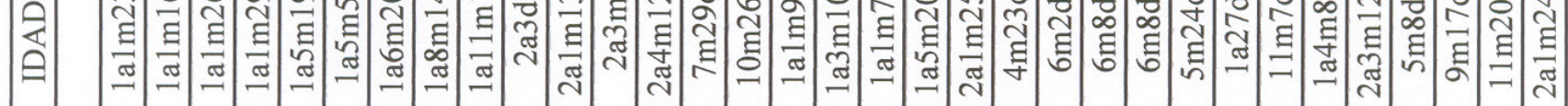

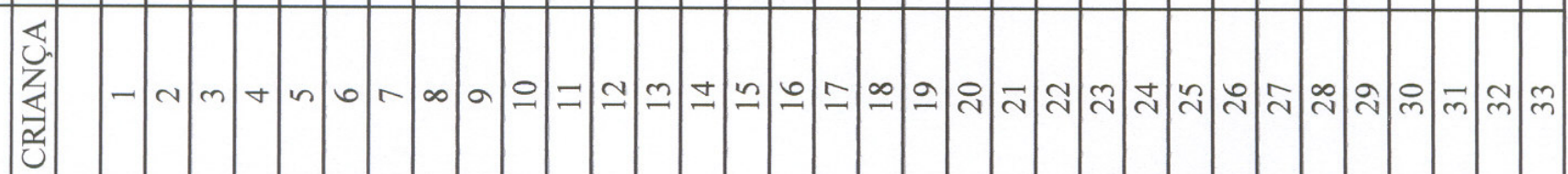

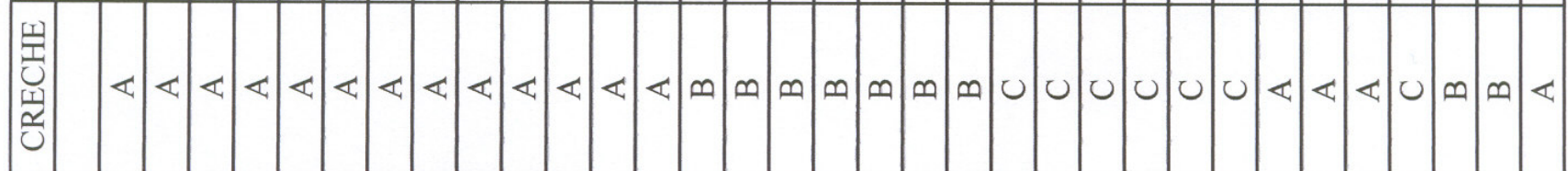




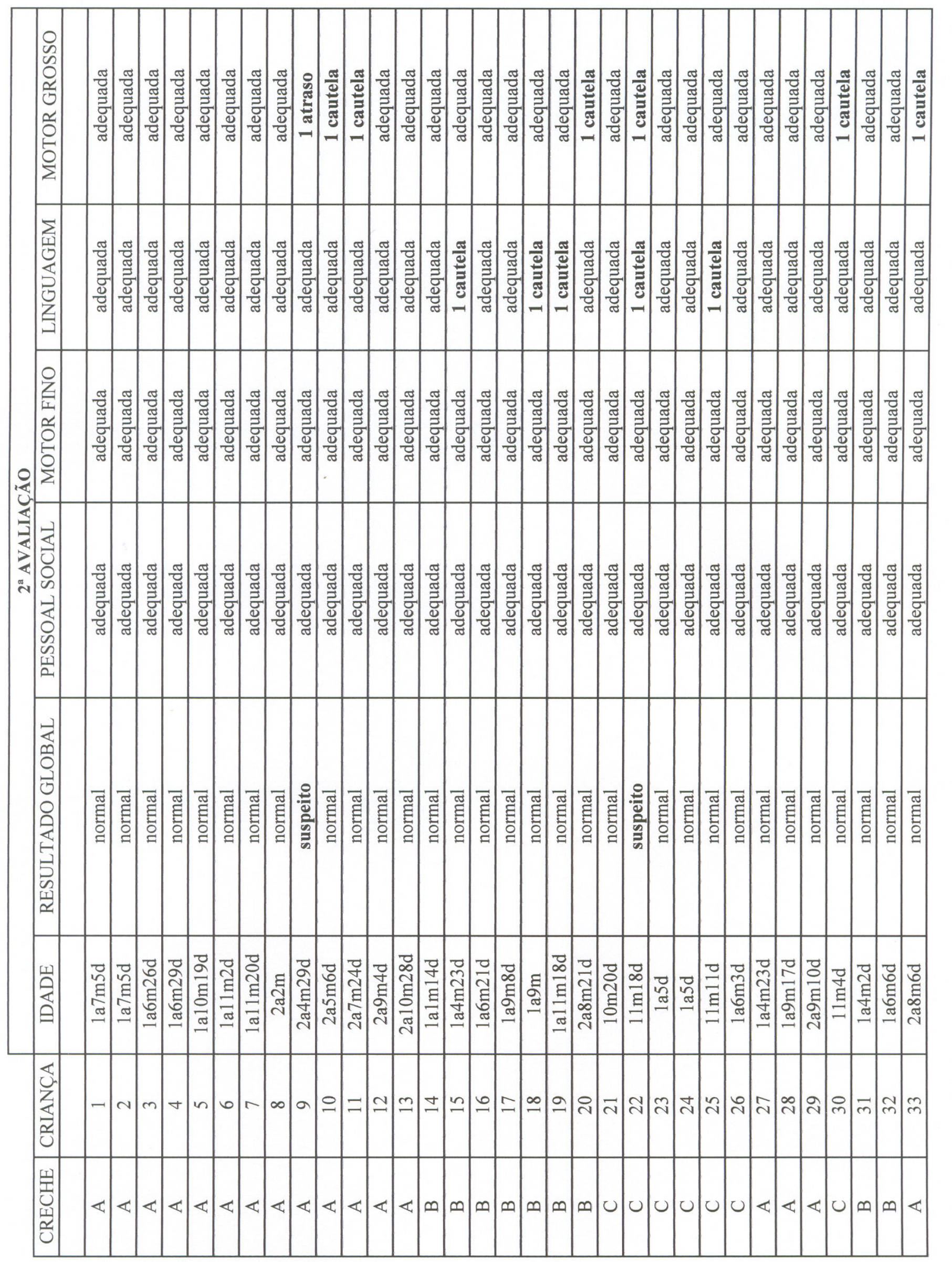




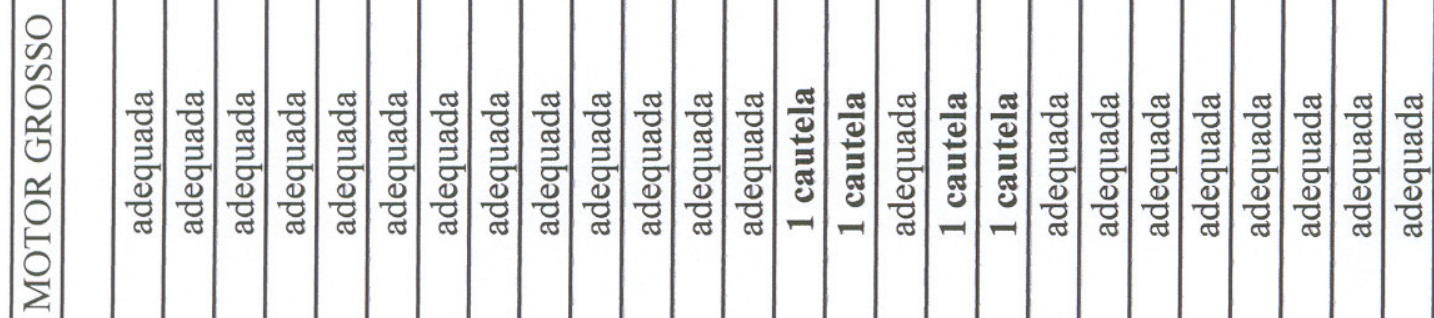

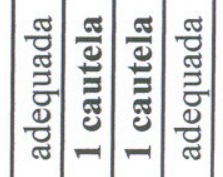

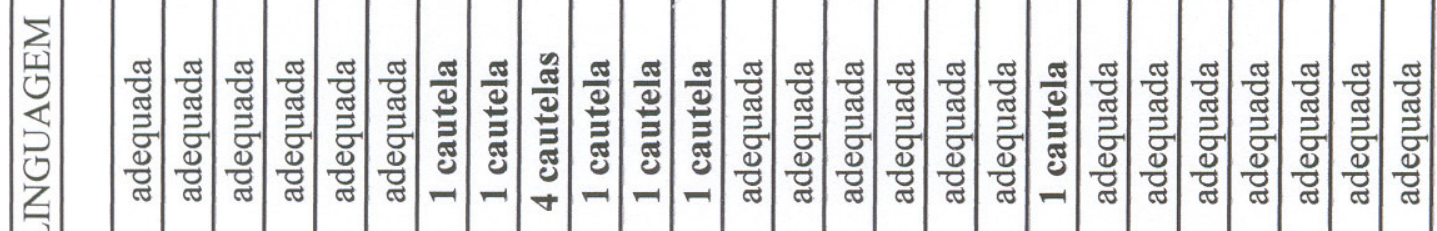

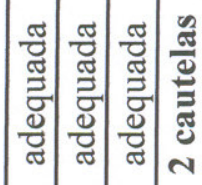

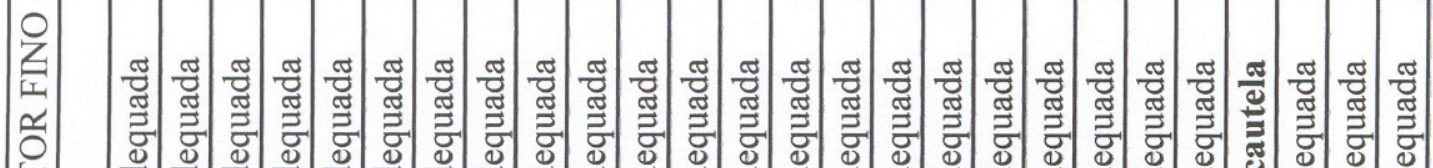

全

菴

离

行

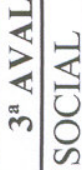

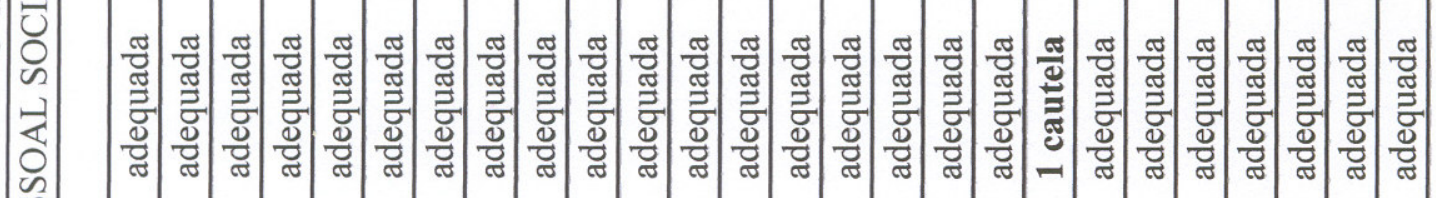

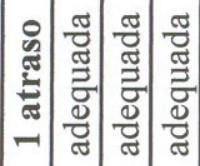

武

난

จิด

0

:

䛼

疍

ᄀ ส

要

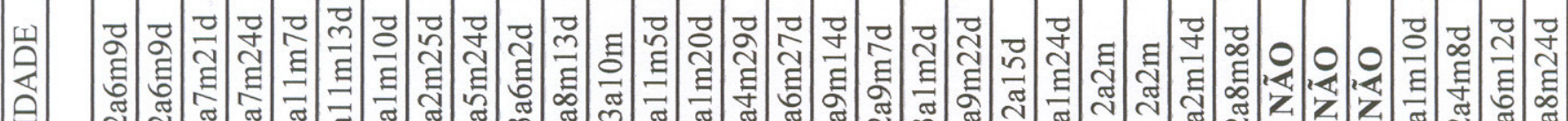

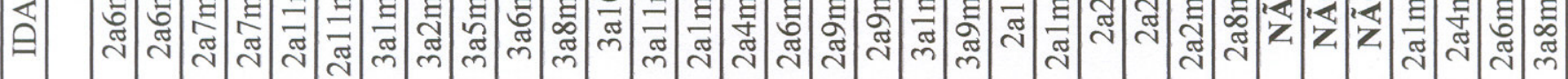

$\varangle$

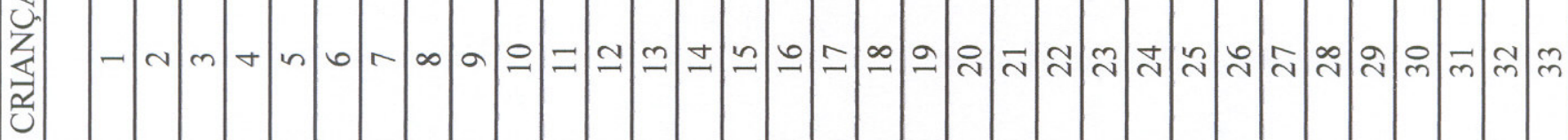

国

突

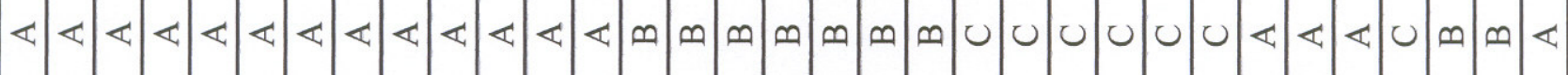




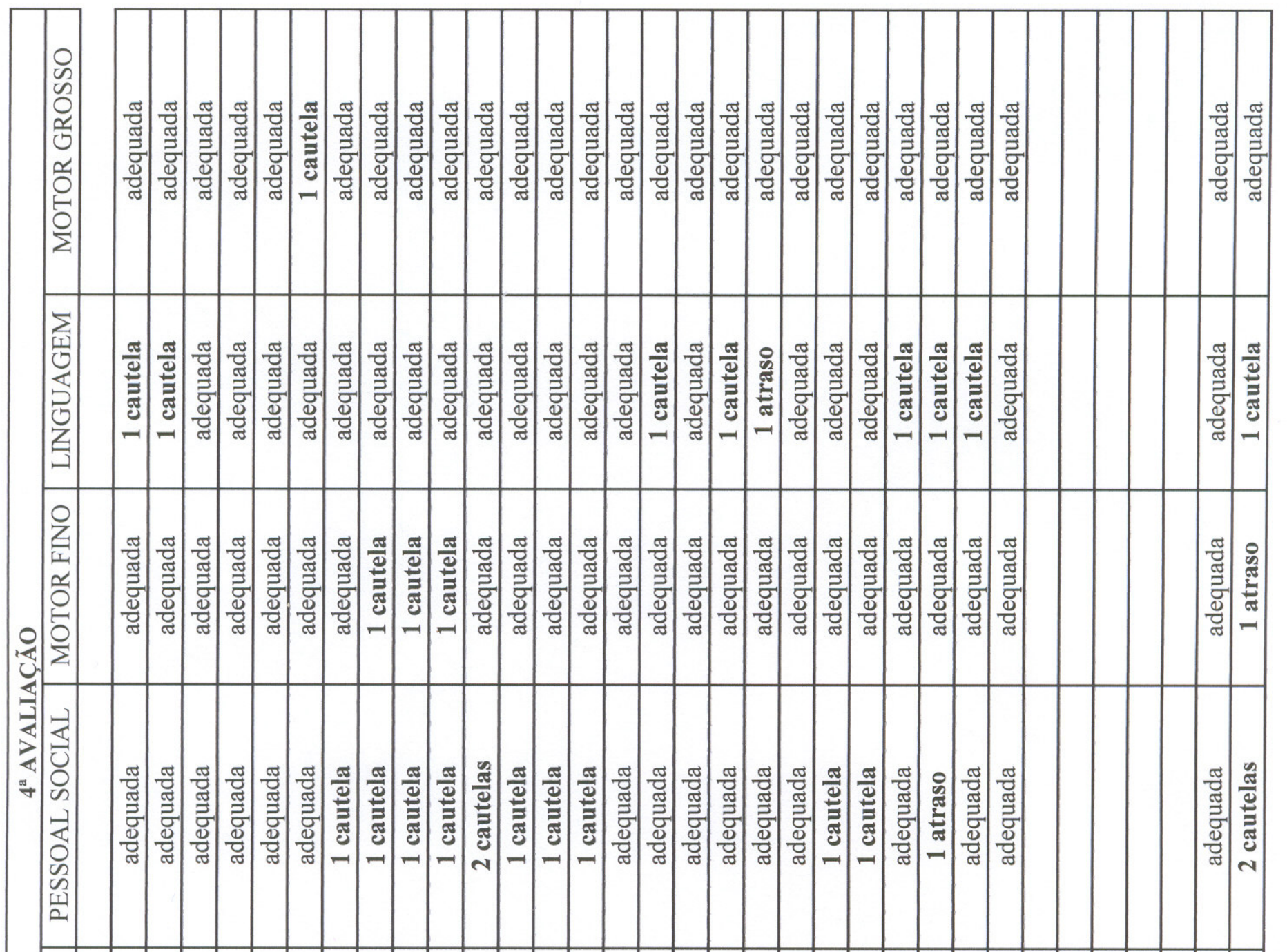

浐

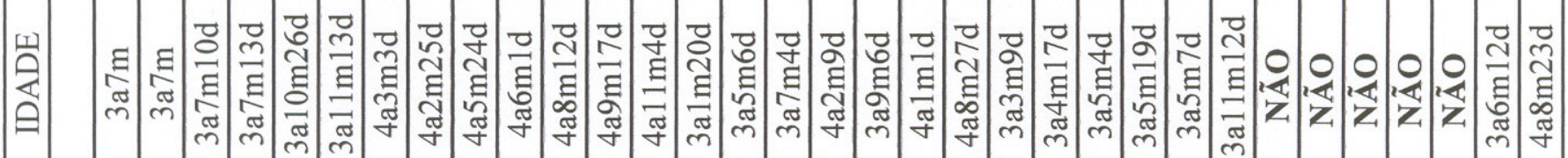

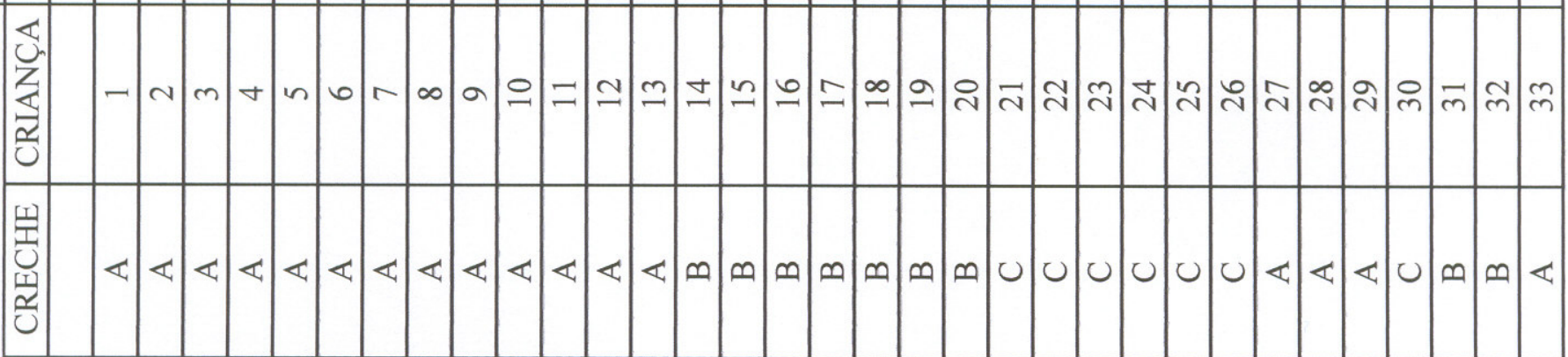




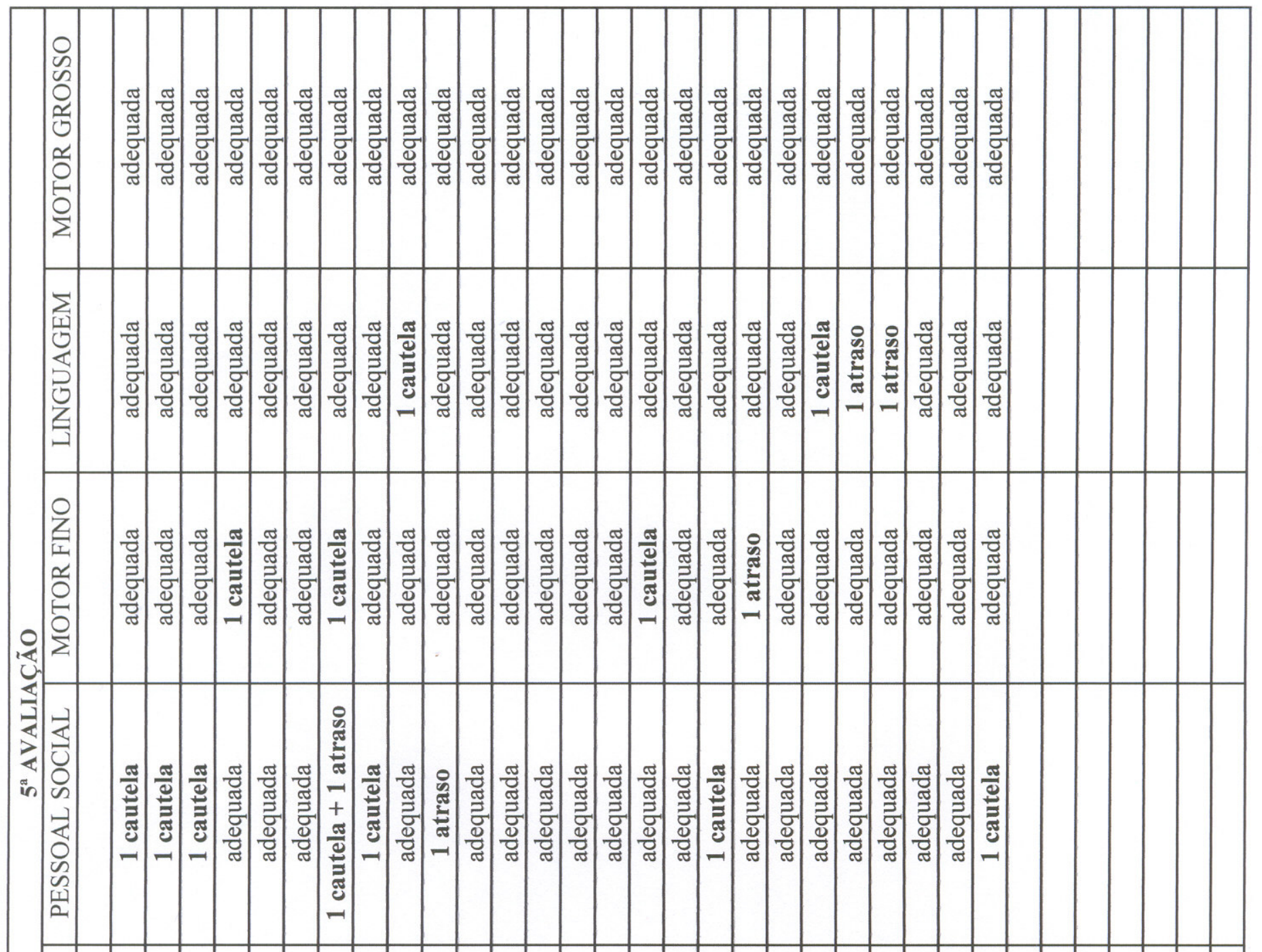

还

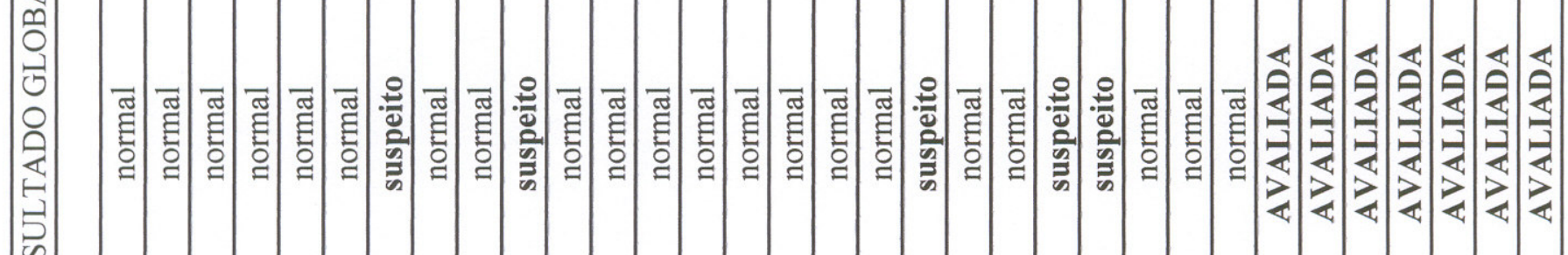

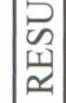

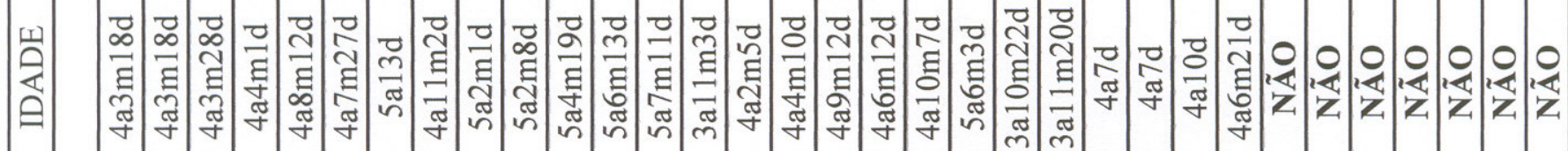

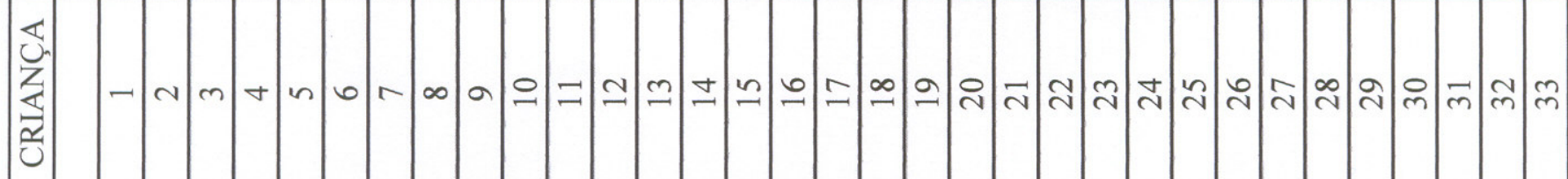

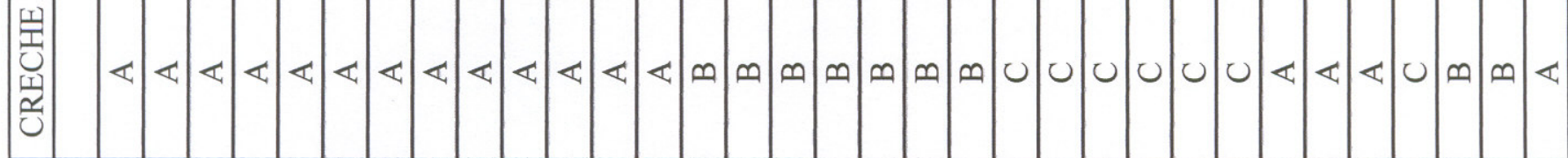



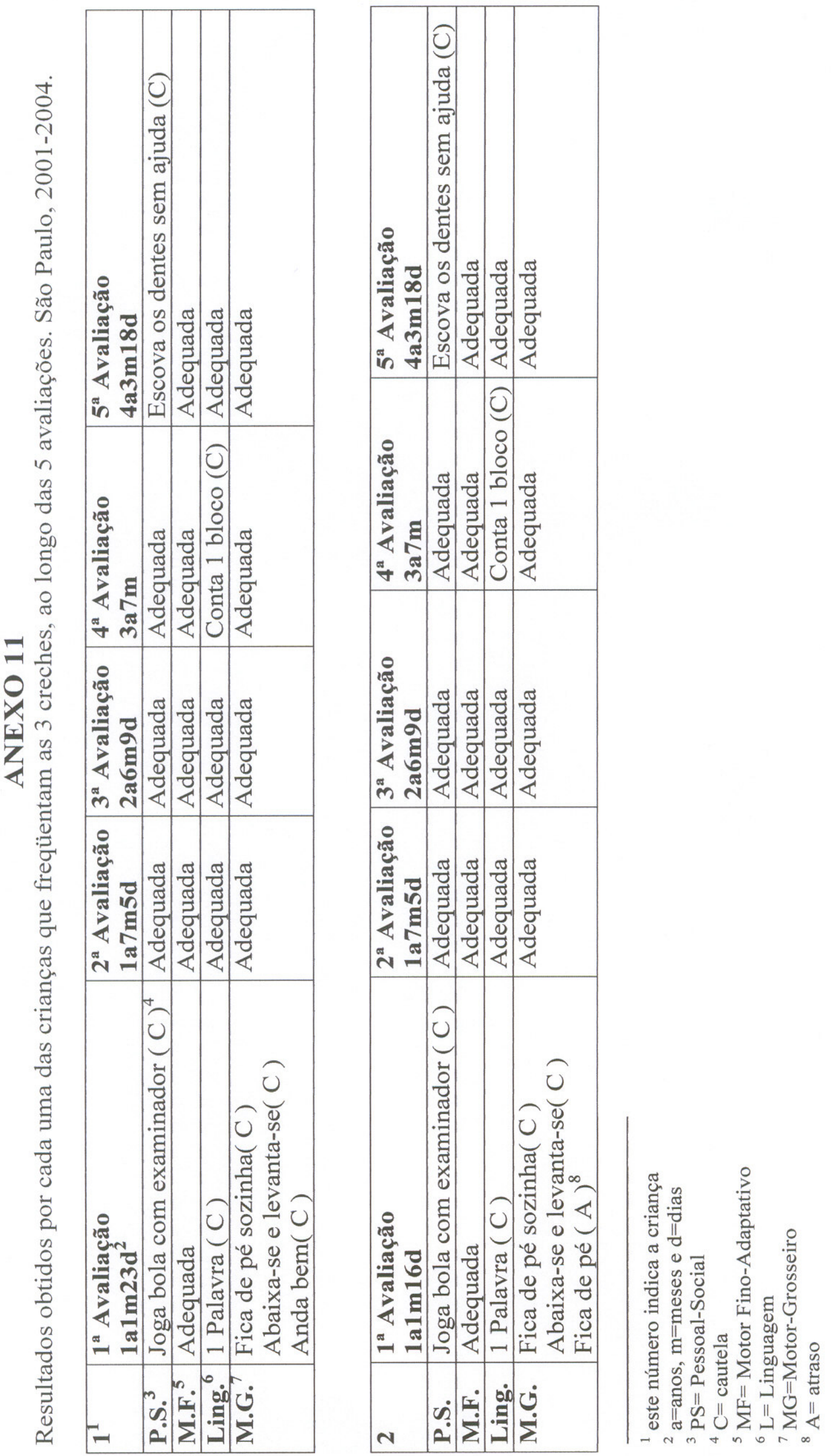

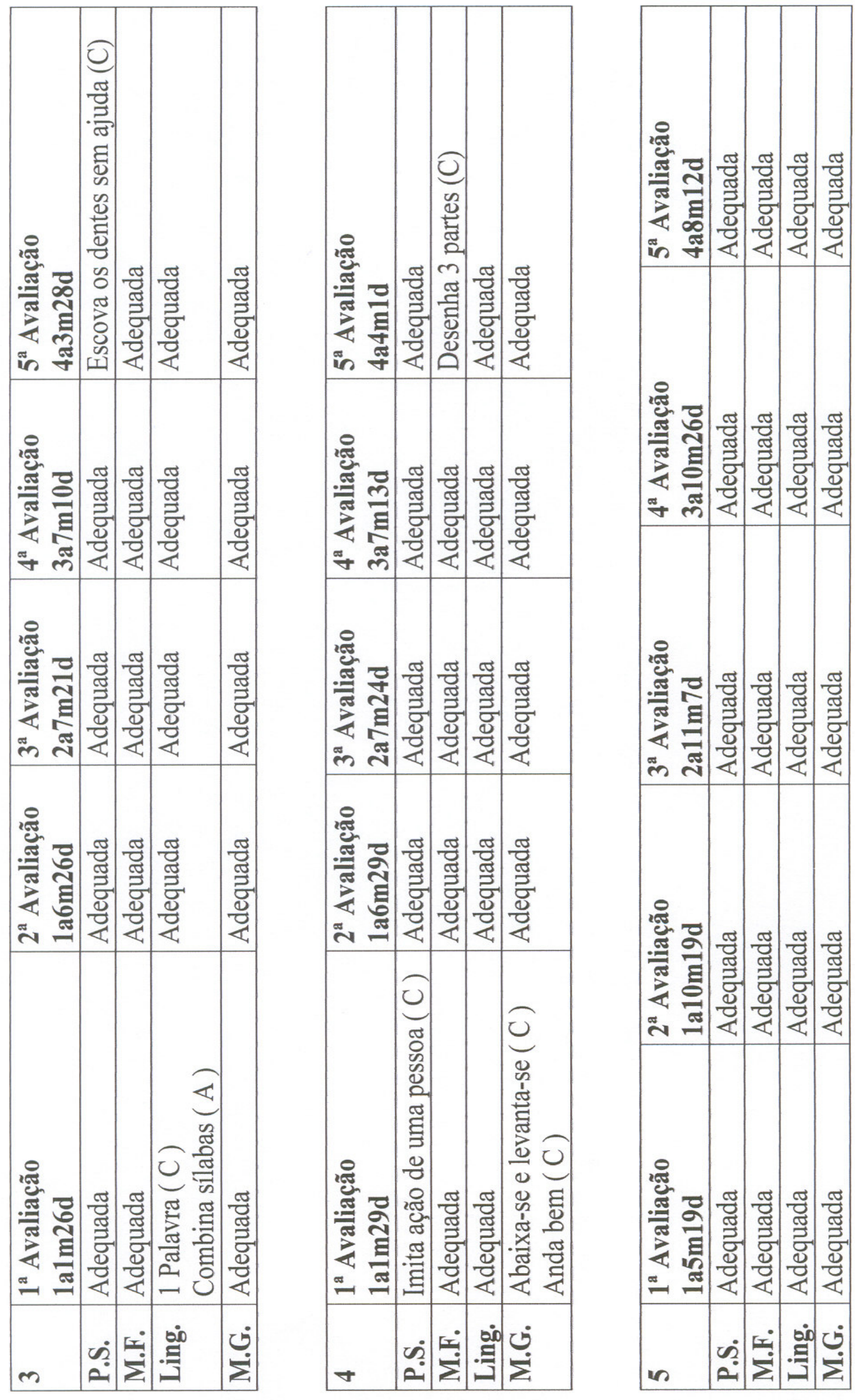

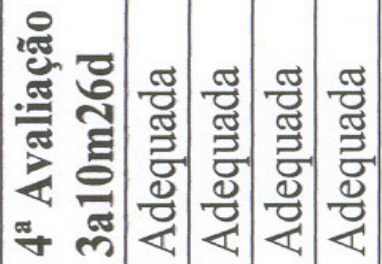

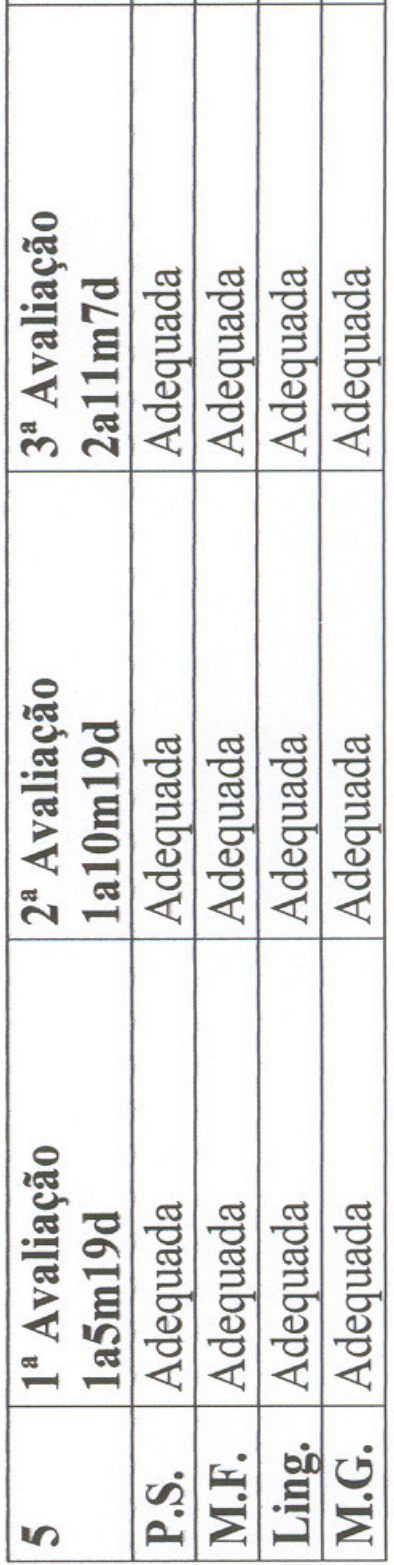



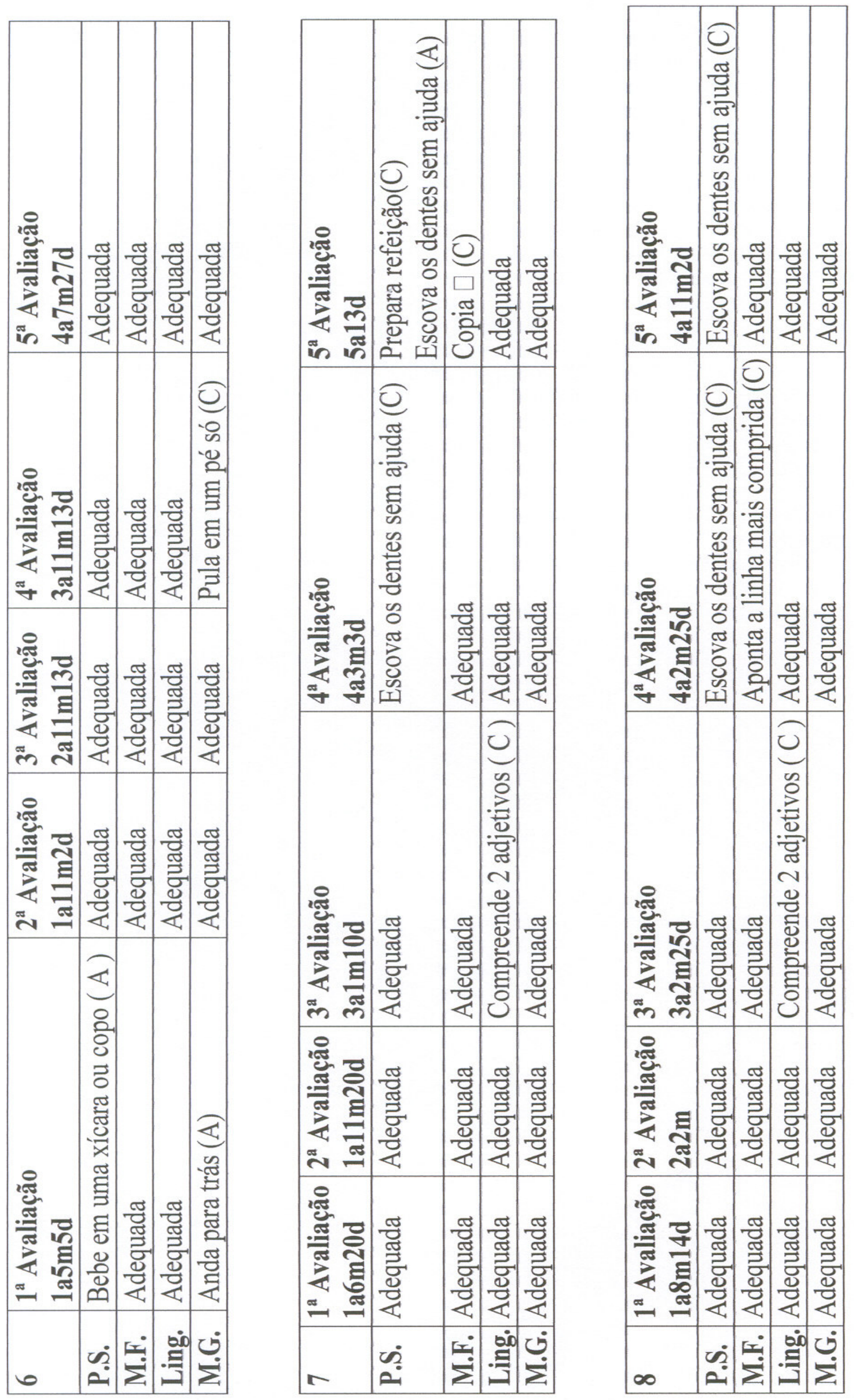

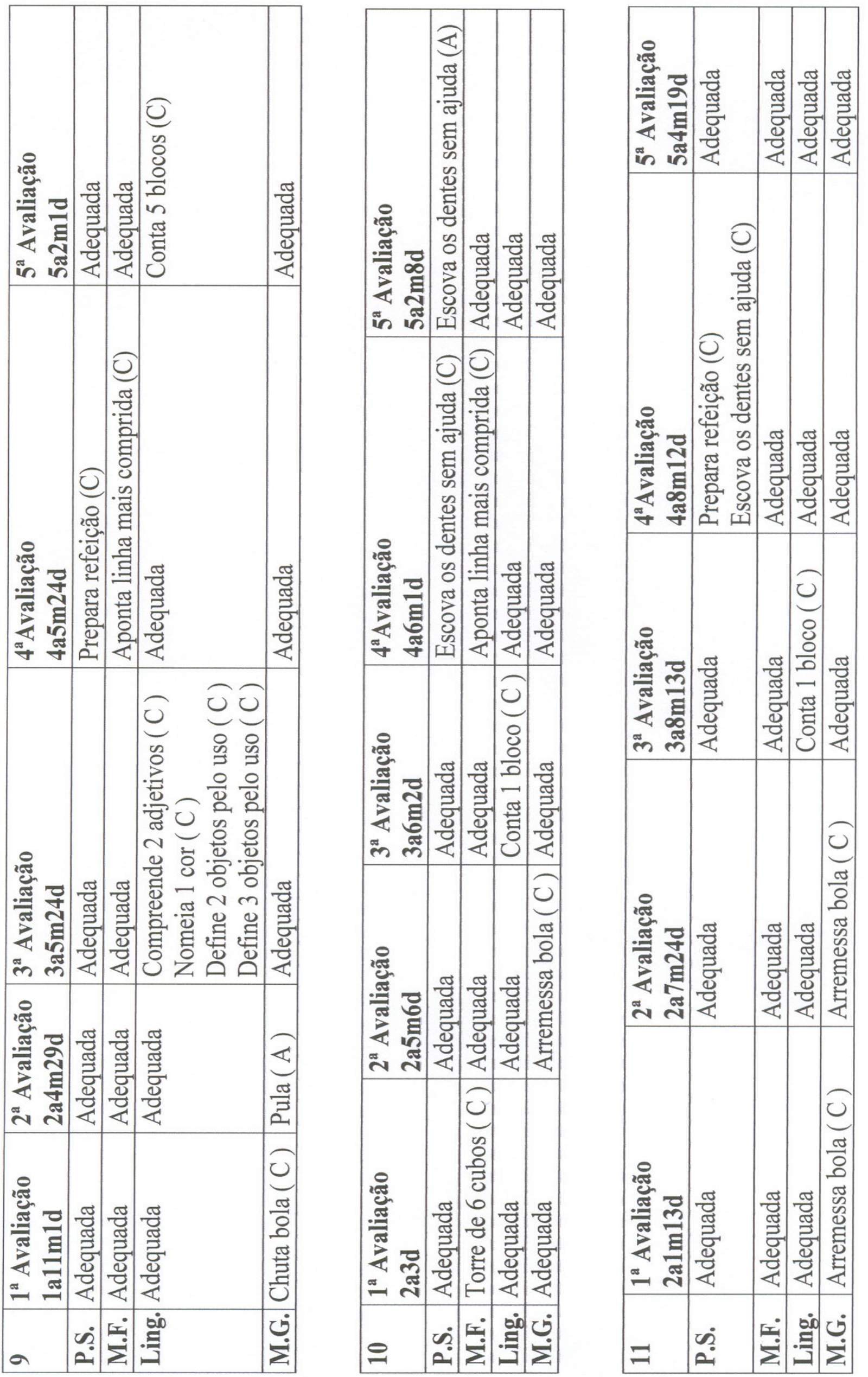

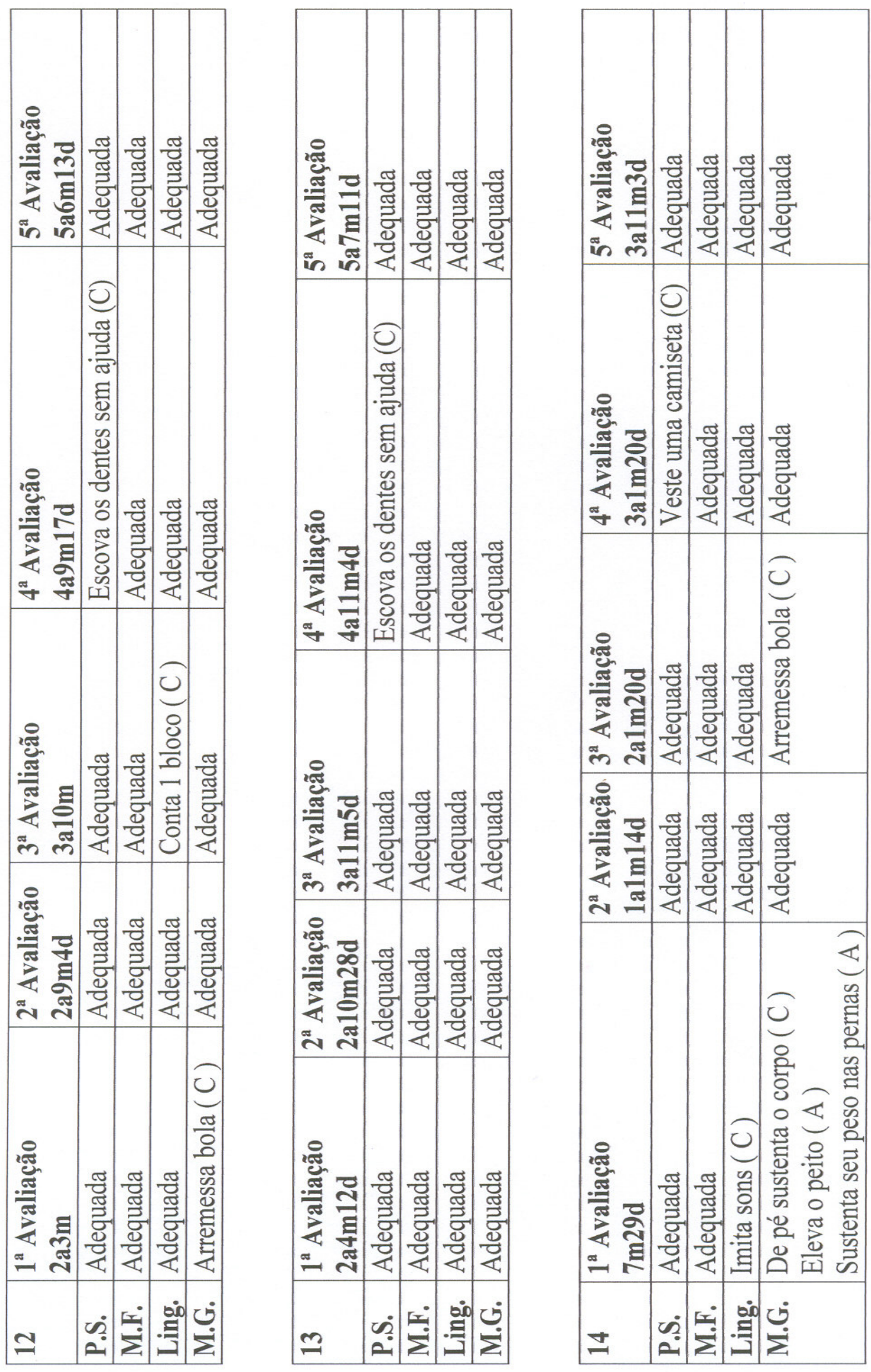

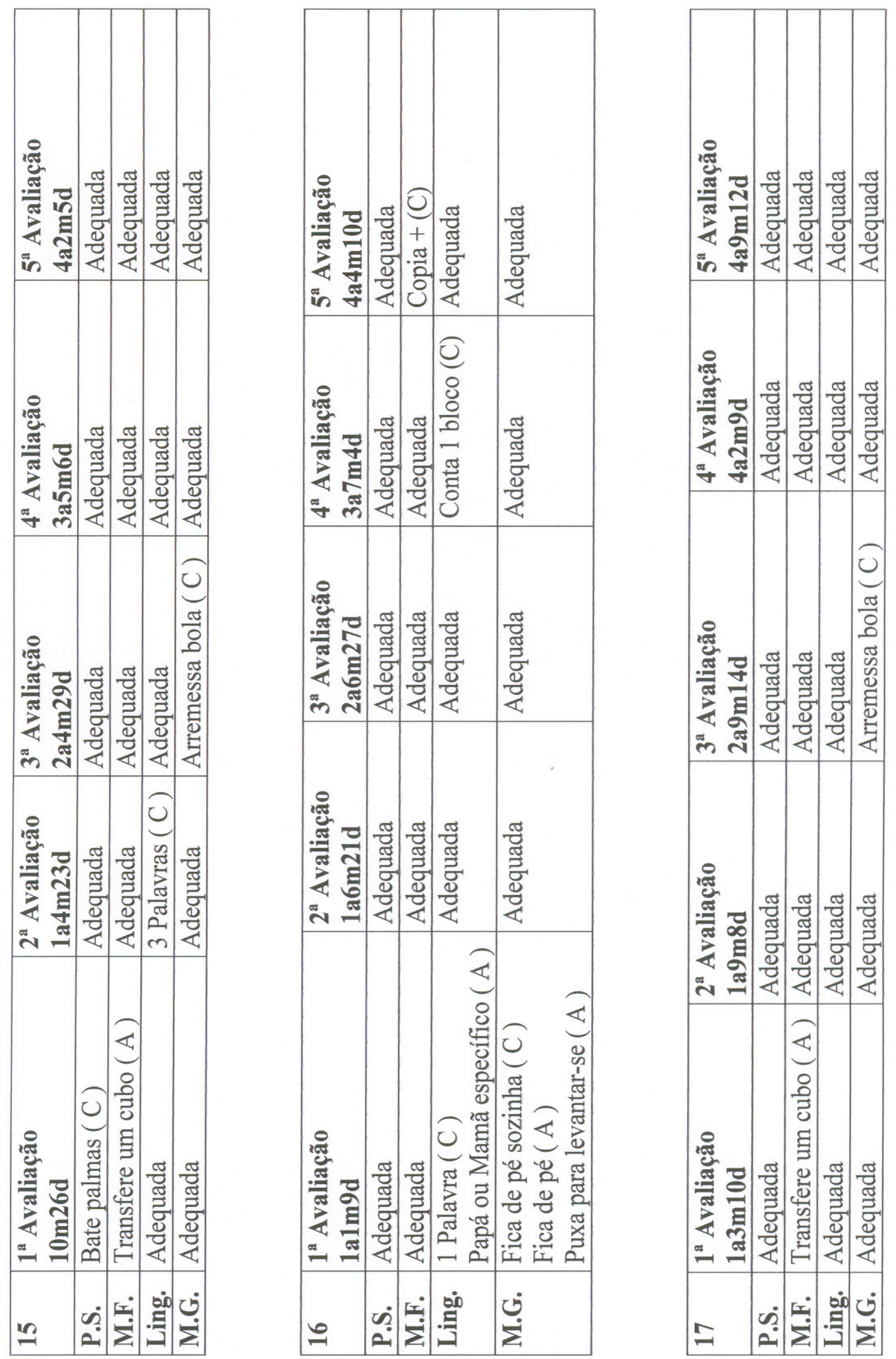

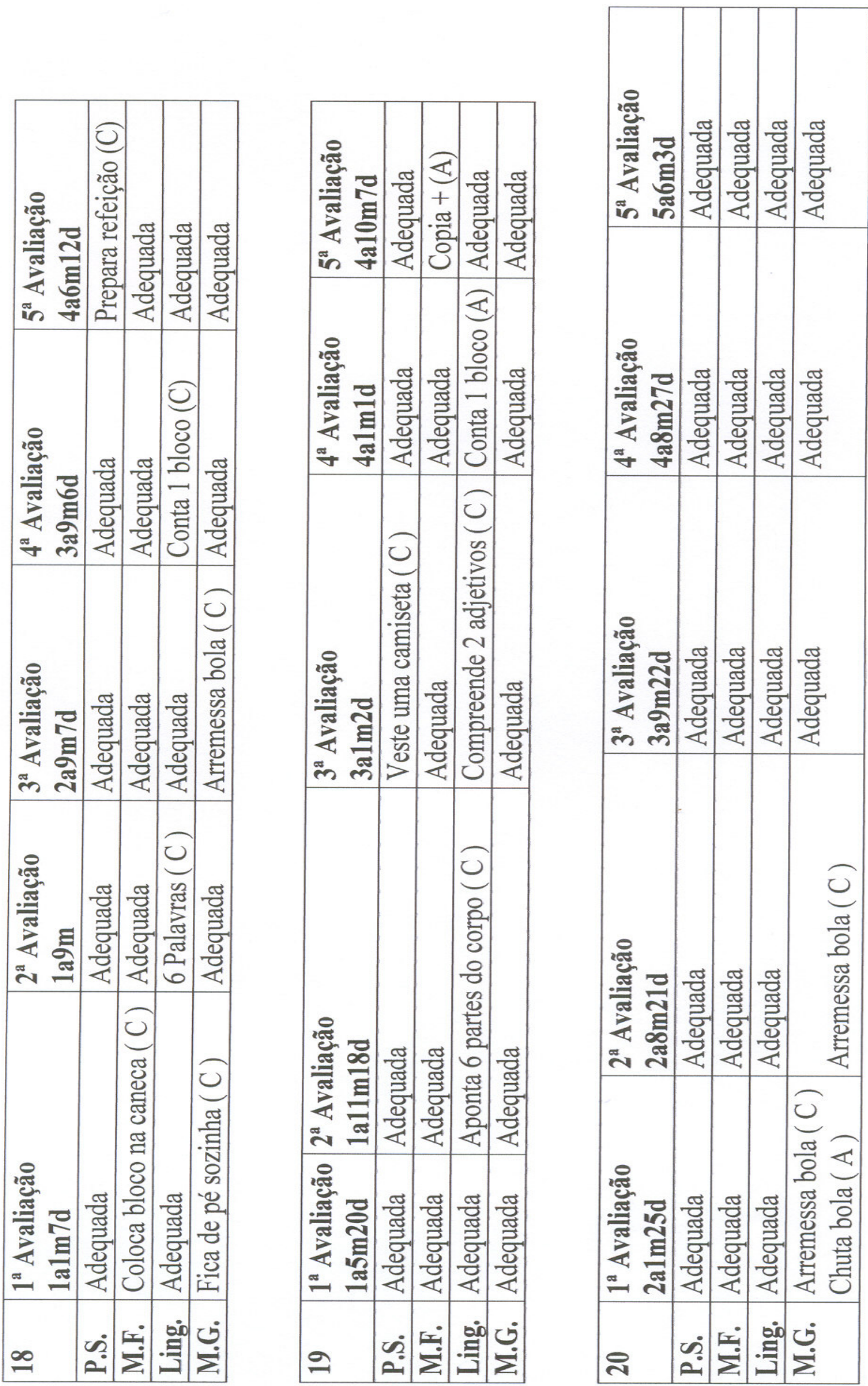

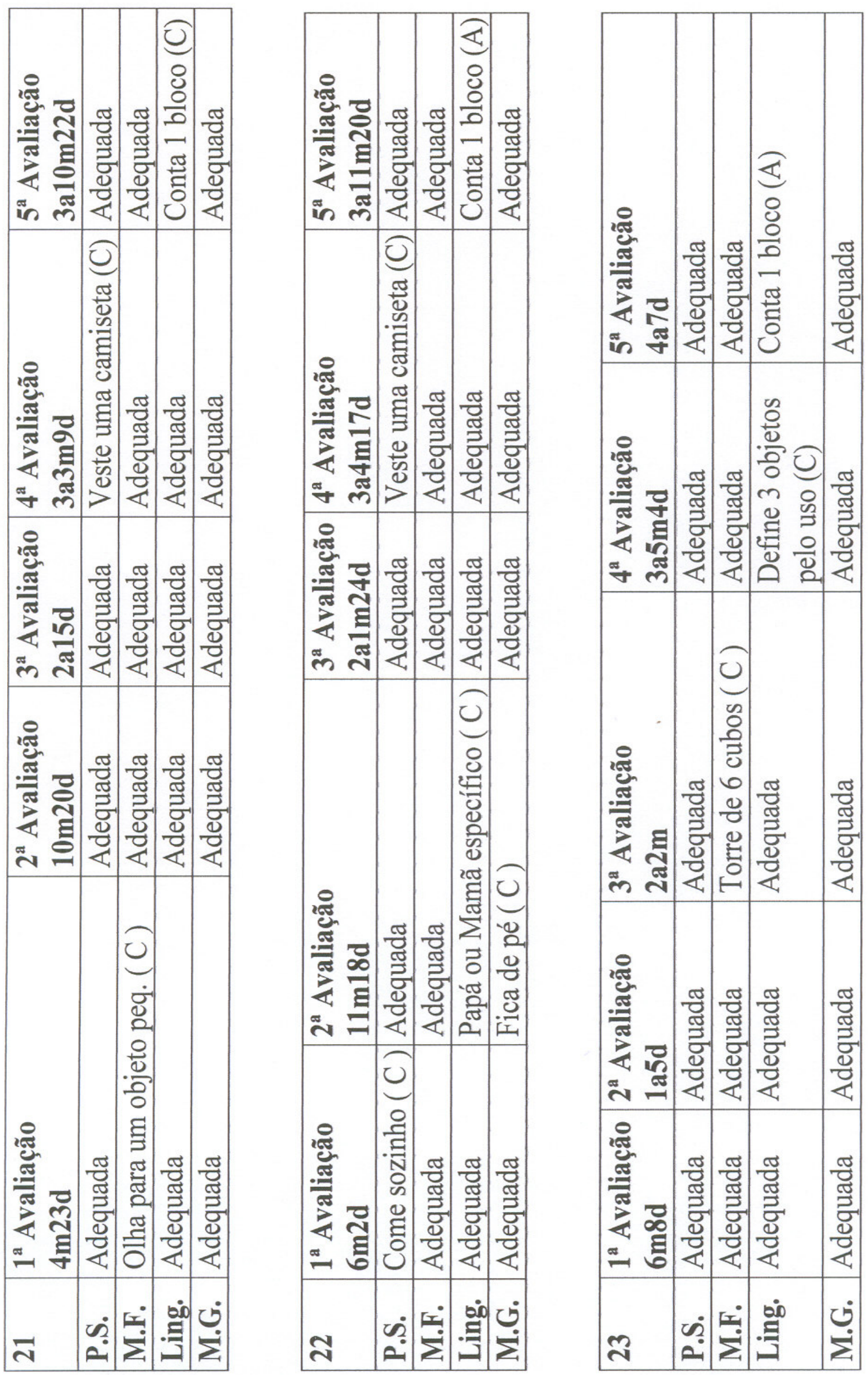

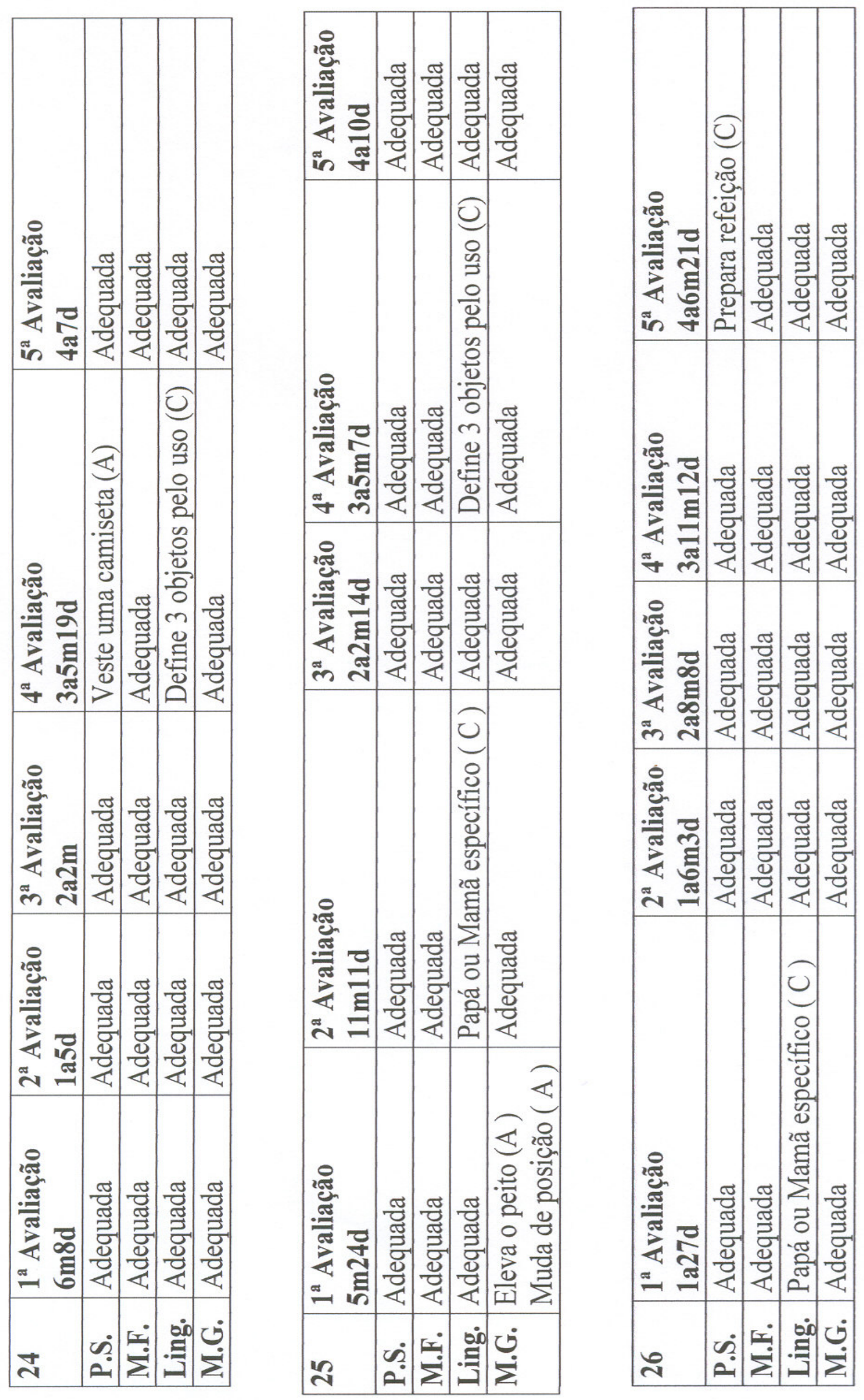


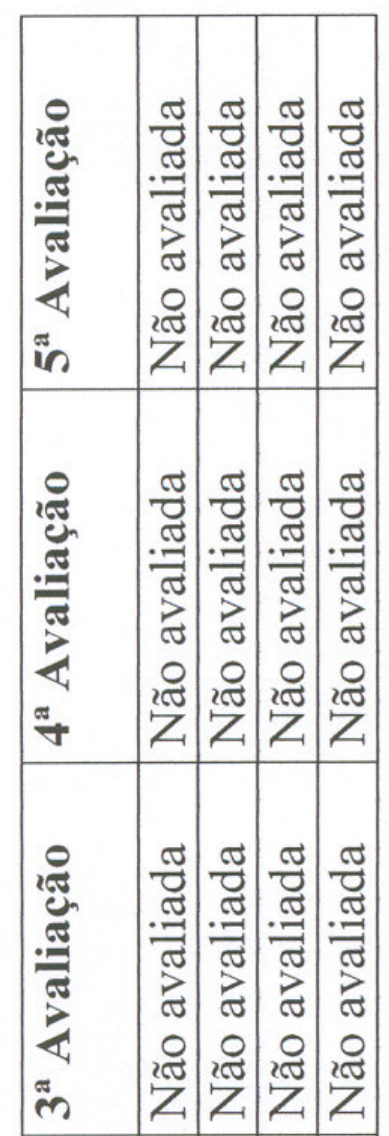

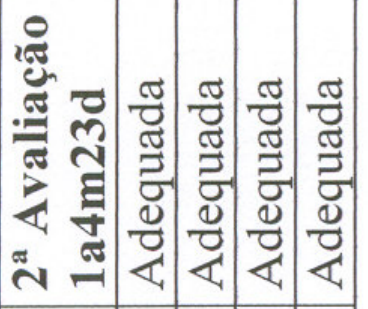

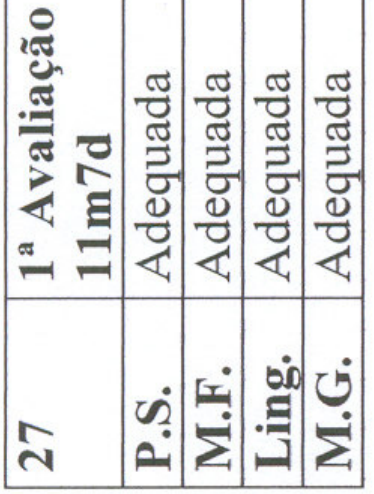



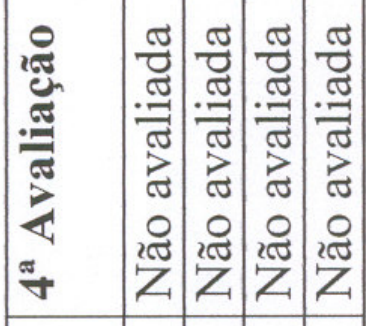

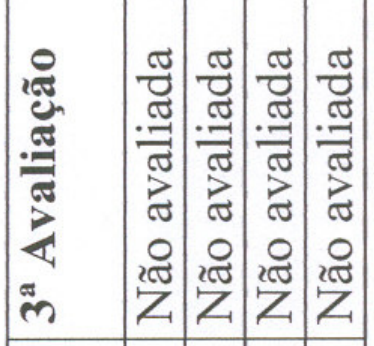

胥

त ज्ञ

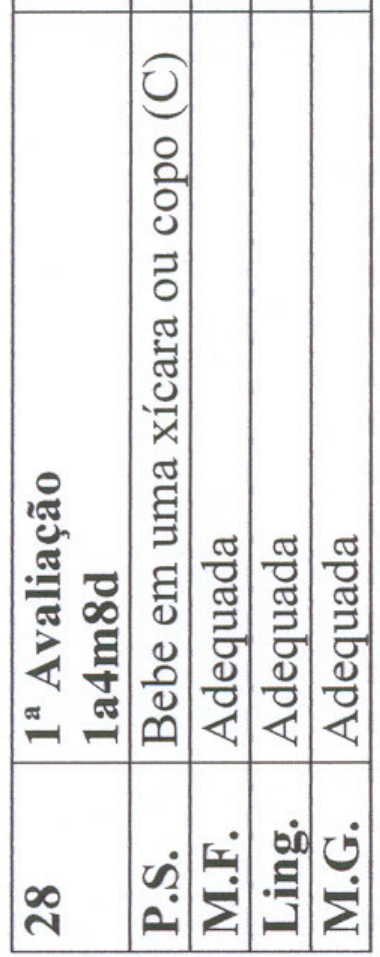

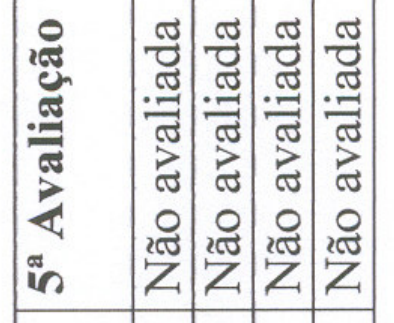

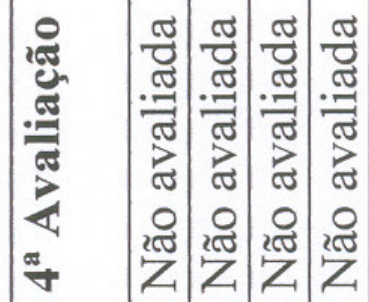

제 $\pi$

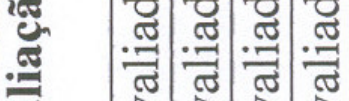

స

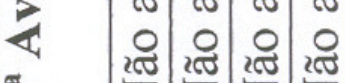

ल Z Z Z Z

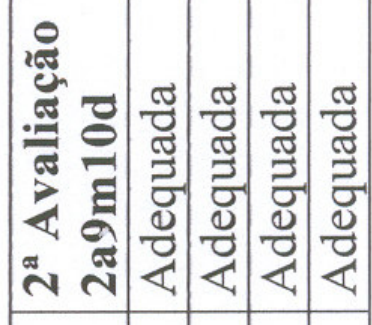

?

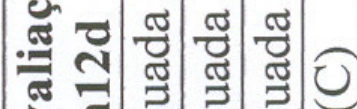

흐 해 휜 한

४ ले ठ ठ

๘

ลิ

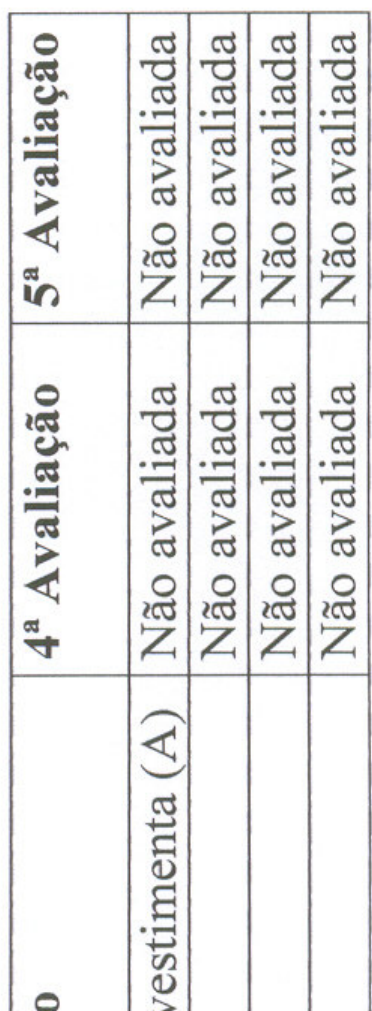

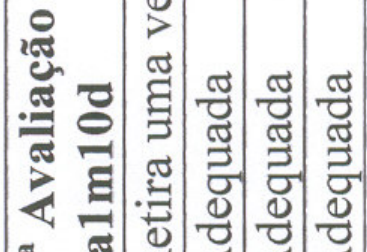

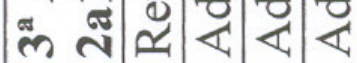

g

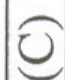

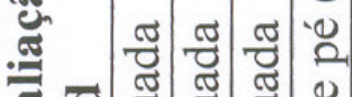

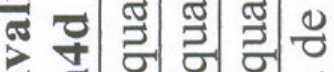

《

픈

త

ఫ్

요

芯

₹

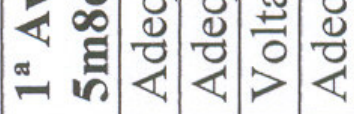

ల 

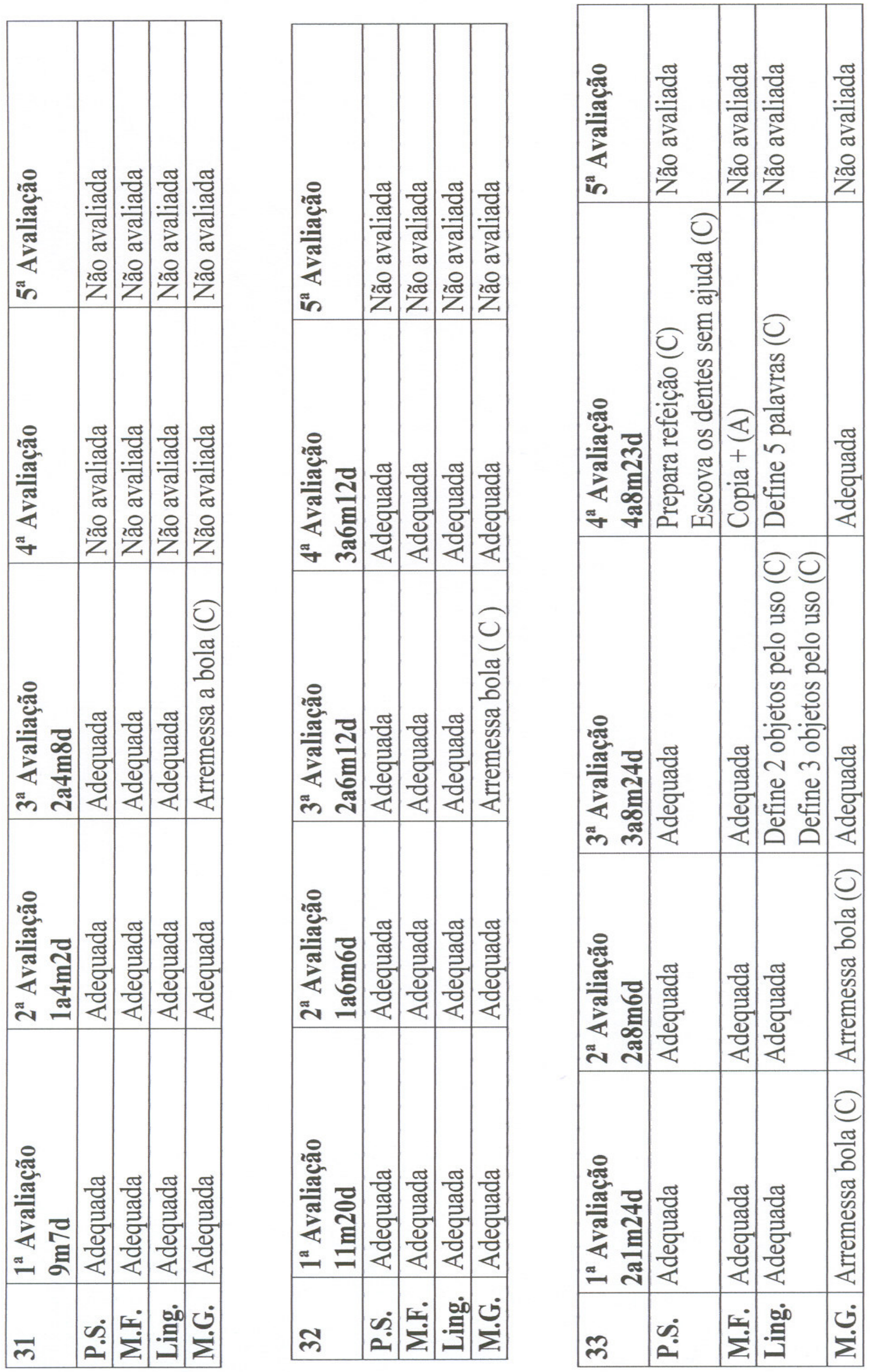